\title{
Gene expression profiling of adult female tissues in feeding Rhipicephalus microplus cattle ticks
}

Christian Stutzer ${ }^{\mathrm{a}}$, Willem A. van Zyl ${ }^{\mathrm{a}}$, Nicholas A. Olivier ${ }^{\mathrm{b}}$, Sabine Richards ${ }^{\mathrm{c}}$, Christine Maritz-Olivier ${ }^{\mathrm{c},{ }^{*}}$

${ }^{a}$ Department of Biochemistry, Faculty of Natural and Agricultural Sciences, University of Pretoria, South Africa, 0002.

${ }^{\mathrm{b}}$ ACGT DNA microarray facility, Department of Plant Sciences, Faculty of Natural and Agricultural Sciences, University of Pretoria, South Africa, 0002.

${ }^{c}$ Department of Genetics, Faculty of Natural and Agricultural Sciences, University of Pretoria, South Africa, 0002.

"Corresponding author:.Tel: +27 012420 3945; fax: +27 0123625327

E-mail address: christine.maritz@up.ac.za

Note: Supplementary data associated with this article.

Note: The microarray and sequence data related to this work is available via the NCBI GEO database, GEO accession no. GSE35867. 


\section{Abstract}

The southern cattle tick, Rhipicephalus microplus, is an economically important pest, especially for resource-poor countries, both as a highly adaptive invasive species and prominent vector of disease. The increasing prevalence of resistance to chemical acaricides and variable efficacy of current tick vaccine candidates highlight the need for more effective control methods. In the absence of a fully annotated genome, the wealth of available expressed sequence tag (EST) sequence data for this species presents a unique opportunity to study the genes that are expressed in tissues involved in blood meal acquisition, digestion and reproduction during feeding. Utilizing a custom oligonucleotide microarray designed from available singletons (BmiGl Version 2.1) and EST sequences of $R$. microplus, the expression profiles in feeding adult female midgut, salivary glands and ovarian tissues were compared. From 13,456 assembled transcripts, 588 genes expressed in all three tissues were identified from fed adult females 20 days post infestation. The greatest complement of genes relate to translation and protein turnover. Additionally, a number of unique transcripts were identified for each tissue that relate well to their respective physiological/biological function/role(s). These transcripts include secreted anti-hemostatics and defense proteins from the salivary glands for acquisition of a blood meal, proteases as well as enzymes and transporters for digestion and nutrient acquisition from ingested blood in the midgut, and finally proteins and associated factors involved in DNA replication and cell-cycle control for oogenesis in the ovaries. Comparative analyses of adult female tissues during feeding enabled the identification of a catalogue of transcripts that may be essential for successful feeding and reproduction in the cattle tick, $R$. microplus. Future studies will increase our understanding of basic tick biology, allowing the identification of shared proteins/pathways among different tissues that may offer novel targets for the development of new tick control strategies.

Keywords: Rhipicephalus microplus; DNA microarray; Salivary gland; Midgut; Ovary 


\section{Introduction}

The southern cattle tick, Rhipicephalus microplus, is a major pest of cattle in the tropical and sub-tropical regions of the world including the South Americas, southern Asia, Madagascar and the southern and eastern coasts of Africa (Lynen et al., 2008). This species is regarded as the most economically devastating tick species worldwide due to three main factors (Guerrero et al., 2006). Firstly, $R$. microplus is a highly adaptable species that is spreading rapidly to occupy previously unaffected areas, such as the Ivory Coast in western Africa and the Limpopo province in South Africa, even displacing endemic tick species (Tønnesen et al., 2004). Secondly, $R$. microplus is a well described vector for the causative agents of Asiatic redwater (Babesia bovis) and bovine anaplasmosis (Anaplasma spp.) (de la Fuente et al., 2007; Madder et al., 2007; Lynen et al., 2008). Thirdly, an increase in resistance to all major classes of acaricides has been reported for this species, as well as the occurrence of a strain resistant to the Bm86-based tick vaccine (de la Fuente et al., 2000; Rajput et al., 2006; Li et al., 2007).

Due to the tremendous impact that this species has on animal health, rationales were provided for whole genome sequencing of $R$. microplus (Guerrero et al., 2006). The genome size of the cattle tick has been estimated at $7.1 \times 10^{3}$ megabases with approximately $60 \%$ constituting repetitive sequences (Ullmann et al., 2005; Pagel van Zee et al., 2007) and assembly of the genome is currently in its primary stages (Moolhuijzen et al., 2011; Bellgard et al., 2012). However, the BmiGI (Boophilus microplus Gene Index) database of 42,512 expressed sequence tags (ESTs) that was derived from various tissues, life stages and geographical strains as well as larvae exposed to various temperatures, host odors and acaricides is available for analysis (Wang et al., 2007).

The BmiGl has been used successfully in high-throughput DNA microarray analyses investigating acaricide-induced gene expression in larvae (Saldivar et al., 2008), organ-specific responses to pathogen infection in male adults (Mercado-Curiel et al., 2011), the transcriptional effects of RNA interference (RNAi)-mediated gene silencing in adult females (Lew-Tabor et al., 2011) as well as responses in feeding larvae and adult females on different cattle species (Rodriguez-Valle et al., 
2010). The vast number of genes that are unannotatable, however, limit the full impact of these studies. The latter is largely due to two factors. Firstly, there is considerable evolutionary distance between ticks and other model organisms, limiting homology-based gene predictions, and secondly limited functional protein data of tick protein sequences is available (Hill and Wikel, 2005; Pagel van Zee et al., 2007).

Papers have been published describing the various sialomes of both hard and soft tick species (reviewed by Mans et al., 2008). However, little is known about the gene expression profiles in the various tissues of feeding adult ticks, especially those involved in blood meal acquisition (salivary glands), digestion (midgut) and reproduction (ovaries). A study using EST sequencing showed that a number of genes are uniquely expressed in both salivary glands and ovaries of feeding, female $R$. microplus (de Miranda Santos et al., 2004). More recently, DNA microarray analyses of the transcriptomes of adult male salivary glands and midgut showed a significant response in gene expression during feeding (Mercado-Curiel et al., 2011). This shows that DNA microarrays are a valid high-throughput approach that can be used to elucidate the underlying molecular processes and biochemical pathways that are involved during tick feeding.

To date, transcriptome analysis has been performed using North and South American, as well as Australian, strains of $R$. microplus (Saldivar et al., 2008; Rodriguez-Valle et al., 2010; MercadoCuriel et al., 2011). However, gene expression profiling of African strains of $R$. microplus on African cattle breeds is lacking. The latter is of vital importance as control of $B$, microplus may vary dramatically in different geographical areas as seen for the Bm86 vaccine (de la Fuente et al., 2000). Therefore, two aims were addressed in this study. Firstly, a custom oligonucleotide microarray platform was designed for the comparison of gene expression in the salivary glands, midgut and ovaries of feeding adult $R$. microplus females ticks from a Mozambique reference strain on a South African Bos indicus cattle breed. Global analyses of gene expression in these tissues demonstrated that a total of 588 transcripts were shared between tissues during feeding, while a number of upregulated transcripts displayed tissue specificity. Secondly, multiple database sequence similarity 
searches and extensive manual curation were employed to functionally annotate transcripts. This study provides a combined functional genomics overview of tissues involved in feeding and reproduction, offering new insights into the complex gene expression profiles related to tissue function and basic $R$. microplus tick biology.

\section{Materials and methods}

\subsection{Tick rearing and sample collection}

Rhipicephalus microplus larvae (Mozambique strain, provided by ClinVet Pty. Ltd, South Africa) were allowed to feed on Holstein-Friesian cattle under controlled conditions at the University of Pretoria Biomedical Research Centre (UPBRC), South Africa. Ethical and relevant Section 20 clearances were obtained from the South African Department of Agriculture, Forestry and Fisheries (ethical clearance number: EC022-10), as well as the University of Pretoria Animal Use and Care Committee. Larvae were allowed to advance through their life stages until mature females dropped off the host animal. Ticks were sampled on days 4, 5, 7, 13, 15 and 20. Adult tissues were collected and processed according to the method of Nijhof et al. (2010). The various tissues were stored in TRI REAGENT $^{\circledR}$ (Molecular Research Center, Inc., USA) at $-70^{\circ} \mathrm{C}$.

\subsection{Microarray probe design from R. microplus sequences}

Using available EST data from GenBank (http://www.ncbi.nlm.nih.gov/nucest/) and the gene index of R. microplus (BmiGl release 2.1) from the Harvard gene index project (http://compbio.dfci.harvard.edu/tgi/tgipage.html), a sequence dataset was assembled from some 60,000 ESTs and 13,643 unique sequences to a final sequence database consisting of 13,456 contiguous sequences, using the online bioinformatic tools, cd-hit-est (http://www.bioinformatics.org/cd-hit/) and cap3 (http://pbil.univ-lyon1.fr/cap3.php). Detection and removal of vector sequences from EST data were performed with the VecScreen tool (http://www.ncbi.nlm.nih.gov/VecScreen/VecScreen docs.html), using the UniVec database 
(http://www.ncbi.nlm.nih.gov/VecScreen/UniVec.html). The final sequence dataset was submitted online for array design using the Agilent $8 \times 15 \mathrm{k}$ microarray and eArray microarray design platforms (https://earray.chem.agilent.com/earray/). A set of 60 mer probes, incorporating a 3' bias for possible incomplete cDNA synthesis, was designed for complete representation of all assembled transcripts. Probe quality was assessed from base composition scores and the probes were randomly distributed across the array. Additional quality control probes and housekeeping controls were included. These are elongation factor 1 alpha (GenBank accession no. EW679365), H3 Histone family 3A (GenBank

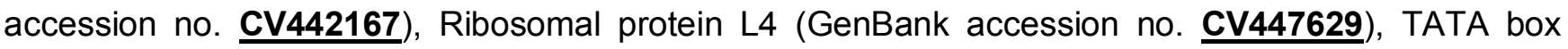

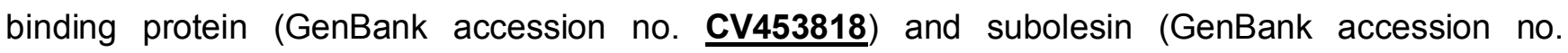
EU301808). Sequences of assembled transcripts used for custom array design, as well as microarray data related to this work, are available from the NCBI GEO public database (GEO accession no. GSE35867). The customized array slide was manufactured by Agilent technologies (USA).

\subsection{Isolation of total RNA and microarray analyses}

Total RNA was isolated according to the manufacturer's guidelines for TRI REAGENT ${ }^{\circledR}$ and purified with the RNeasy kit (QIAGEN, USA). Final RNA concentrations, purity and integrity were assessed with the Nanodrop-1000 (Thermo Fisher Scientific, USA) and the Bioanalyzer 2100 microfluidics systems (Agilent technologies). A reference RNA pool consisting of equivalent amounts of RNA from each life stage and adult tissue was prepared in order to allow the independent analysis of both immature and mature life stages. Test groups for the current study consisted of tissues (salivary gland, midgut and ovary) collected from 15 partially fed females (day 20), from two biological replicates.

High quality DNase I-treated total RNA was used for cDNA synthesis using SuperScript ${ }^{\mathrm{TM}}$ III (Invitrogen $^{\mathrm{TM}}$ life technologies, USA), an oligo ( $\mathrm{dT}_{25}$ ) primer (5'-(T) ${ }_{25} \mathrm{VN}-3^{\prime} ; \mathrm{N}=\mathrm{ATGC} ; \mathrm{V}=\mathrm{AGC}$ ), random nanomers and aminoallyl dUTP for Cyanine 3-dCTP/Cyanine 5-dCTP dye coupling. Template was labeled with Cy3 (reference pool) or Cy5 (test sample), purified using the QIAquick PCR purification kit 
(QIAGEN, USA) and the concentration and coupling efficiency determined using the Nanodrop-1000 system (Thermo Fisher Scientific Inc., USA). Equivalent picomoles of Cy3-labeled cDNA from the common reference pool were hybridized with Cy5-labeled individual test cDNA. Both biological and technical replication were employed for each test sample. Hybridization was performed at $65^{\circ} \mathrm{C}$ for 17 h. Prior to scanning, each slide was washed, rinsed and dried in Stabilization and Drying Solution (Agilent Technologies). Following a drying step, slides were scanned with the GenePixTM 4000B microarray laser scanner (Molecular Devices Inc., USA).

\subsection{Microarray data analysis and functional annotation}

Fluorescence intensities of hybridized Cy3- and Cy5-labeled probes were extracted using default parameters in the GenepixPro microarray feature extraction software (v6.0, Axon Molecular Devices, USA). Following manual inspection to evaluate spot quality, flagged features were given a zero weight and not considered for further analysis. Normalization within slides was performed using the Limma package in R (hhtp://cran.r-project.org/), employing locally weighted scatterplot smoothing (LOWESS), followed by Gquantile normalization between slides. The Limma package was subsequently used to calculate the $\log _{2}$ fold change between each group pair-wise comparison, using an empirical Bayes ANOVA to identify significantly differentially expressed transcripts with a $P$ value adjusted for multiple comparison false discovery rates. Comparisons with $P$ values $\geq 0.001$ were ignored. In order to identify transcripts that are organ-specific, only genes with $\mathrm{M}$ values $>0$, a Cy5 intensity $>1,000$ and a $\log _{2}$ fold expression of one or greater in a single organ relative to all other tissues examined, were considered. All transcripts with a $\log _{2}$ fold expression higher than 2 were considered as highly up-regulated under the current chosen conditions. Transcripts with $\mathrm{M}$ values $>0$ and Cy5 expression intensity $>1,000$, in all of the tissues tested, were considered shared (nondifferentially expressed) under the current chosen conditions. In this regard, all transcripts with expression intensity higher than 2,000 were considered strongly shared. 
In order to functionally annotate transcripts, the desktop cDNA Annotation System (dCAS) (v.1.4.3) was used (Guo et al., 2009). BLAST searches were done for each transcript against the following databases: GO, KOG, Mit-Pla, NR, Pfam, RRNA and SMART (http://exon.niaid.nih.gov). BLAST search results were stored in a tab-delimited file by dCAS; these were manually inspected and final annotations were based on consensus between two or more databases, using an expected value (E value) cutoff of less than $1 \times 10^{-6}$. All transcript descriptions were based on consensus with database entries from Uniprot (http://www.uniprot.org/uniprot/) and BRENDA (http://www.brenda-enzymes.org/) in the case of enzymes. Transcripts were finally classified into functional groups based on the eukaryotic orthologous group terms for gene ontology (Tatusov et al., 2003).

\subsection{Validation of microarray results using relative quantitative reverse transcriptase-PCR (qRT-PCR)}

For the verification of gene expression results, transcripts encoded by Contigs 1, 5396, 5672 and 8723 were selected and primer sets were designed for use in relative qRT-PCR analysis (Supplementary Table S1). Using the same RNA isolated for microarray hybridizations, cDNA was synthesized using the iScript ${ }^{T M}$ cDNA synthesis kit (BioRad, Hercules, USA). The cDNA was utilized for relative qRT-PCR using the KAPA SYBR ${ }^{\circledR}$-FAST qPCR kit (KAPA Biosystems, USA) in a $10 \mu \mathrm{l}$ final reaction volume containing 2.5 pmoles of oligonucleotide primer pairs corresponding to selected sequences that were differentially expressed. For each primer set a no template negative control reaction was performed. The mRNA levels were normalized against Contig 8723 , as well as elongation factor 1 alpha that was previously validated as a reference gene (Nijhof et al., 2009). Relative semi-quantitative PCR was performed in triplicate on a LC480 ${ }^{\circledR}$ light cycler (Roche Applied Science, USA) using cycling parameters consisting of an activation step at $95^{\circ} \mathrm{C}$ for $5 \mathrm{~min}$, followed by 45 cycles of $95^{\circ} \mathrm{C}$ for $3 \mathrm{~s}, 55^{\circ} \mathrm{C}$ for $7 \mathrm{~s}$ and $72^{\circ} \mathrm{C}$ for $1 \mathrm{~s}$. Melt curve analysis consisted of a $95^{\circ} \mathrm{C}$ hold for $30 \mathrm{~s}$, followed by incubation at $55^{\circ} \mathrm{C}$ for $30 \mathrm{~s}$ and a slow increase to $95^{\circ} \mathrm{C}$, with continuous signal measurement. The relative transcript levels for selected genes were evaluated using the extracted $\mathrm{Cq}$ values and expressed as a fold change (on a $\log _{2}$ scale) relative to the reference genes using qBase 
(Hellemans et al., 2007). Normalized values were used to calculate the fold change for selected transcripts and linear regression analysis was performed to correlate fold changes calculated by qRTPCR to the fold changes determined from microarray data.

\section{Results and Discussion}

\subsection{Gene expression in feeding R. microplus adult female tissues}

Expression analysis identified 5,175 transcripts differentially expressed among all tissues above threshold, representing $38 \%$ of the total number of contigs (Table 1). Less than $13 \%(1,707$ transcripts) displayed significant expression in any given tissue or comparison (Table 1, Fig.1A). A set of 588 transcripts was found to be expressed in all three tissues (Supplementary Table S2). Of these, 135 transcripts were identified with more than double the intensity threshold for expression. In addition, several tissue-specific transcripts were identified that were uniquely up-regulated in salivary glands (171 transcripts), midgut (310 transcripts) and ovaries (417 transcripts) (Fig.1A, Table 1, Supplementary Tables S3-S5). Therefore, a total of 1,005 transcripts were expressed in ovaries, followed by 898 transcripts in midgut and 758 transcripts in salivary glands when shared transcripts are included (Tables 1, 2).

\subsection{Microarray data validation by $q R T-P C R$}

For verification of microarray results, relative qRT-PCR was performed on randomly selected transcripts from the tissues tested (Supplementary Table S6). These transcripts were: a putative angiotensin-converting enzyme (Contig 1), a putative mucin (Contig 5396) and an unknown secreted protein (Contig 5672). An additional stably expressed 60S ribosomal protein (Contig 8723) was identified (Supplementary Table S6). This transcript was used as an additional reference gene for data normalization (results not shown). When individual fold change values determined from qRT-PCR analysis were expressed relative to each other, a high degree of correlation (0.96) to microarray data was determined (Supplementary Table S6). An overall concordance was observed in the direction and 
magnitude of fold change values obtained. However, it has been stated previously that quantitative gene expression analyses require a large set of reference genes to obtain a stable fold change (Rodriguez-Valle et al., 2010). As only a few reference genes are currently known that could correlate with gene expression data (Nijhof et al., 2009), there is a great need for the identification of new reference genes of different abundance classes (low, medium and high) for use in expression analyses.

\subsection{Unique transcripts highly regulated in adult female salivary glands}

To obtain a blood meal successfully, evasion of host defences against tick attachment and prolonged feeding time is of primary importance. Around 171 transcripts were identified that were salivary gland-specific, of which $70 \%$ could not be functionally annotated or classified into a specific ontology (Fig. 1B, Tables 1, 2, and Supplementary Table S3). The major functional classes that were represented related to defence mechanisms (6.4\%), protein turnover (4.7\%), amino acid transport and metabolism (3.5\%), as well as extracellular structures $(3.5 \%)$

\subsubsection{Defense mechanisms and blood meal acquisition}

Defense proteins represent the major functional class identified for salivary glands comprising $6.4 \%$ (11 transcripts) of the total complement of tissue-specific transcripts (Fig. 1B, Table 2, Supplementary Table S3). These include putative protease inhibitors such as serine protease inhibitors or serpins (Contig 1520, Contig 6586, CK178656 and Contig 688) that are similar to those described in other tick species (Anderson et al., 2008; Francischetti et al., 2010; Chalaire et al., 2011). Trypsin inhibitor-like cysteine rich domain-containing (TIL) proteins (Contig 8207) with putative antielastase, as well as antimicrobial activities, were also up-regulated (Fogaça et al., 2006; Sasaki et al., 2008). Other protease inhibitors related to the thyroglobulin type-1 repeat containing proteins or thyropins (Contig 300) and the alpha-2-macroglobulin family (Contig 2131 and Contig 1745) were 
identified. Thyropins have been proposed to act as inhibitors of cysteine proteases, as well as binding partners for heparin (Anatriello et al., 2010; Francischetti et al., 2010). Alpha-2-macroglobulins are universal protease inhibitors involved in clearance of exogenous proteases and innate immunity. These proteins have been identified in both hard and soft tick species (Saravanan et al., 2003; Buresova et al., 2009). Additional well described defense transcripts that were highly up-regulated in salivary gland tissues included putative lipocalins or tick histamine binding proteins (Contig 2493 and Contig 2529) (Mans et al., 2008).

Antimicrobial defense proteins specific to salivary glands were identified that are orthologous to R. microplus cysteine-rich microplusin and defensin peptide proteins (Contig 5482 and CK177092). Defensins have been described from the midgut of Ornithodoros moubata (Nakajima et al., 2002), as well as various tissues including the salivary glands of Amblyomma americanum (Todd et al., 2007). However, microplusin and defensin proteins have only been localized previously to the fat body, ovaries and hemocytes in $R$. microplus female ticks (Fogaça et al., 2004). An additional novel $R$. microplus transcript (Contig 5501), sharing $\sim 30 \%$ sequence similarity with invertebrate astakine cytokines, was uniquely up-regulated in salivary glands. A similar protein sharing $38 \%$ sequence identity was previously identified from the sialome of Amblyomma variegatum (Ribeiro et al., 2011). Astakines are well described effectors in hematopoiesis in crustaceans, whereas related vertebrate prokineticin homologues have also been implicated in a number of biological processes including smooth muscle contraction (Lin et al., 2011). A putative serine proteinase (Contig 486) was identified as a transcript that may be involved in amino acid transport and metabolism, however this transcript showed high sequence identity $(\sim 80 \%)$ to a factor D-like transcript identified from Dermacentor variabilis that has been suggested to have antimicrobial activity (Simser et al., 2004).

\subsubsection{Nutrient transport and metabolism}

A group consisting of six transcripts with putative functions in amino acid transport and metabolism, representing $3.5 \%$ of the salivary gland-specific transcripts, was identified (Fig. 1B, Table 
2). Of these, two transcripts encoding putative amino acid and peptide converting enzymes were highly up-regulated (Supplementary Table S3): an aspartate amino transferase (Contig 1049), as well as an angiotensin-converting enzyme (ACE) (Contig 1) identical to the previously characterized Bm91 protein from R. microplus (Riding et al., 1994). ACE is an exopeptidase that plays a role in mediation of extracellular volume and vasoconstriction in mammals, as well as in reproduction in insects (Isaac et al., 1999; Macours et al., 2004). The ACE transcript has one of the highest log expression values of the salivary gland-specific transcripts, correlating with previous findings that this enzyme represents a major membrane component of $R$. microplus salivary glands (Jarmey et al., 1996). The Bm91 protein also showed an improved efficacy in subsequent vaccination trails when used in combination with Bm86 (Willadsen et al., 1996).

Proteases have been implicated in acquisition of the blood meal as anti-hemostatics and antiinflammatories, extracellular matrix degradation molecules for blood pool formation, as well as possible pre-oral digestive enzymes (Ribeiro et al., 2006; Batista et al., 2008). In line with the latter, putative cysteine proteases containing signal sequences for secretion from the $\mathrm{C} 1$ peptidase family (Contig 6614 and Contig 1050) were identified (Supplementary Table S3). Similar proteins have only been identified from midgut tissues of $R$. microplus (Kongsuwan et al., 2010).

A transcript with one of the highest log fold expressions of salivary gland transcripts (3.78), encodes a putative aquaporin involved in water and small neutral solute transport (CV443183). Aquaporins have been shown to be closely involved in salivation (Bowman and Sauer, 2004). However, knockdown experiments in Ixodes ricinus did not display a significant phenotype, indicating that additional factors are present (Campbell et al., 2010).

\subsubsection{Structural proteins, signal transduction and other proteins}

Similar to other studies in salivary glands, we identified putative glycine-rich (GGY) cuticlerelated (CV437645) and cement (Contig 2328) proteins that may be involved in structural interactions of the peritrophic matrix between the cuticle and salivary gland tissues, in addition to cement cone 
formation during attachment (Francischetti et al., 2010; Maruyama et al., 2010), as well as putative mucins (CV452616 and CV444691) (Francischetti et al., 2010). A vaccination trial using a mucin isolated from female $R$. microplus homogenates could not demonstrate greater protection against infestation compared with that of Bm86 (McKenna et al., 1998).

A unique signal transduction transcript was up-regulated in salivary glands, sharing sequence similarity to mitogen-activated protein kinase kinase kinase 1 (MEKK1) (Contig 4877) (Table 2). Similar transcripts have been identified from other tick sialomic data, however not $R$. microplus (Francischetti et al., 2010). MEKK1 is a signal transducer protein of C-Jun $\mathrm{N}$-terminal protein kinase (JNK) and extracellular signal-regulated kinase (ERK) pathways that are involved in cytoskeleton regulation, cell migration and focal adhesion (Uhlik et al., 2004).

A number of putative proteins involved in protein synthesis and trafficking (CK177403, Contig 5601, CV454094 and Contig 470) were also highly up-regulated in salivary glands that have been previously described from sialomic data of ixodid ticks, including $R$. microplus (Supplementary Table S3) (Francischetti et al., 2010).

\subsection{Unique transcripts highly regulated in adult female midgut}

The midgut represents the first major internal tick tissue barrier encountered by ingested blood and microbes. Unfortunately over $50 \%$ of midgut-specific transcripts could not be functionally annotated (Fig. 1C), while 123 annotatable transcripts were highly up-regulated (Tables 1, 2, and Supplementary Table S4). The major functional classes relate to lipid transport and metabolism (7.1\%), amino acid transport and metabolism (6.1\%), signal transduction (5.8\%), protein modification and turnover $(5.8 \%)$, as well as defense mechanisms $(4.8 \%)$.

\subsubsection{Defense mechanisms and blood meal acquisition}

A total of 18 midgut-specific transcripts with putative defense functions were identified, representing the largest subset of defense transcripts for all tissue comparisons (Table 2, 
Supplementary Table S4). Of these, 11 transcripts involved in anti-coagulation belonging to four families of protease inhibitors were identified: the reversible papain-like cysteine protease (cystatin) inhibitor family (Contig 5662, CV444905 and Contig 1698), the Kunitz-type serine proteinase inhibitors (TC22004, CK192299 and CK192837), serpins (Contig 1086, CV442792 and Contig 165) and TIL proteins (CV443795 and CK188782) (Supplementary Table S4). These protease inhibitors have been recently identified from the mialome of $D$. variabilis and have been well described from tick siolomic data (Anderson et al., 2008; Francischetti et al., 2010).

Four putative antimicrobial transcripts that share sequence similarity with soft tick antimicrobial proteins were identified in midgut tissues (Contig 4731, Contig 4907, Contig 5243 and Contig 5493). The antimicrobial peptide, microplusin, was previously localized to the fat body, hemocytes and ovaries of engorged females, but not the midgut (Fogaça et al., 2004). Therefore, the transcripts identified in this study represent a unique set of related proteins that are midgut-specific. Interestingly, no defensins were identified in the midgut, which correlates with previous findings by Fogaça et al. (2004).

It has been suggested that digested blood is a source of oxidative stress as heme, a prooxidant, is released following hemolysis (Citelli et al., 2007). Glutathione S-transferases or GSTs (Contig 8822, Contig 336 and Contig 706) and cytochrome P450 enzymes (Contig 894, U92732.1 and CV443756) were identified that were up-regulated in gut tissues (Supplementary Table S4). These enzymes are known to be involved in detoxification and management of oxidative stresses and have been found to be highly expressed during feeding in previous comparative studies of $R$. microplus larvae and adults on different cattle breeds (Rodriguez-Valle et al., 2010). Furthermore, GSTs have also been shown to play a vital role in acquired acaricide resistance in $R$. microplus larvae (Saldivar et al., 2008). Numerous proteins involved in the management of oxidative stress, anti-microbial defense, inhibition of host immune responses and maintenance of the blood meal fluidity have been described in the midgut of various tick species, including R. microplus (Uhlik et al., 2004; Horn et al., 2009; Kongsuwan et al., 2010; Mercado-Curiel et al., 2011). 


\subsubsection{Nutrient transport and metabolism}

Catabolism and acquisition of nutrients for basic metabolism and oogenesis from the blood meal are essential functions of the digestive tract. It therefore requires expression of a number of genes involved in the processing and transport of proteins, carbohydrates and lipids.

\subsubsection{Proteins and amino acids}

Numerous putative proteases involved in protein and amino acid metabolism were identified including: chymotrypsin-like serine proteases (Contig 598, Contig 3850, Contig 1821), asparaginyl peptidases or legumain-like proteases (Contig 1863), cathepsin peptidases (Contig 6100, Contig 953, Contig 3558, Contig 1506, Contig 3719, Contig 432 Contig 2640 and TC15264), elastase-like peptidases (Contig 6406) aminopeptidases (Contig 5171), serine-type endopeptidases (Contig 5340), carboxypeptidases (Contig 4941 and Contig 5462) and non-specific dipeptidases (Contig 506) (Supplementary Table S4). Considering the most prominent class of up-regulated proteases, the aspartic and cysteine (cathepsin) peptidases, these have been implicated in the hemoglobinolytic pathway in I. ricinus and D. variabilis midgut (Anderson et al., 2008; Sojka et al., 2008; Horn et al., 2009). Similar enzymes have been implicated in the production of potent antimicrobial hemocidins in R. microplus (Cruz et al., 2010). Proteome analysis of the midgut of partially fed female $R$. microplus ticks also identified type $\mathrm{L}$ and $\mathrm{B}$-like cathepsins (with $\sim 60 \%$ sequence identity to midgut-specific transcripts), as well as other metalloproteases (Kongsuwan et al., 2010). A putative pantetheine hydrolase (CV440582) involved in cellular recycling of pantothenic acid (vitamin B5) and oxidative stress was also highly up-regulated (Supplementary Table S4) (Pitari et al., 2000). This enzyme type has been identified in other ixodid ticks from comparative sialomic data only (Francischetti et al., 2010).

Novel putative amino acid converting enzymes have also been identified as highly upregulated in midgut tissues that may function in asparagine (Contig 1748), cysteine (Contig 8186), 
glycine (Contig 2855), ornithine (Contig 6808), methionine (Contig 3884) and arginine (Contig 8859) metabolism (Supplementary Table S4). Similar enzymes have been identified from sialomes ESTs for R. microplus (Francischetti et al., 2010).

\subsubsection{Carbohydrates}

A group of novel midgut up-regulated enzymes involved in carbohydrate metabolism were identified (Supplementary Table S4): glucosylceramidase (Contig 7972) involved in sphingolipid metabolism (Hannun and Obeid, 2008), a hexokinase (Contig 245B) that functions in fructose and mannose metabolism (glycolysis and gluconeogenesis) (Wilson, 2003), putative alpha-L-fucosidases (Contig 8580 and Contig 4273) that hydrolyze the carbohydrate moieties in glycoproteins (Johnson and Alhadeff, 1991), as well as glycoprotein- $\mathrm{N}$-acetylgalactosamine 3-beta-galactosyltransferase (CV448648) involved in glycoprotein synthesis (Ju et al., 2002). Similar enzyme activities were identified from the midgut homogenates of the blood-feeding phlebotomine sand fly, Lutzomyia longipalpis, but not in R. microplus (Gontijo et al., 1998).

Additional novel transporters were identified that were higly up-regulated: a putative sialic acid cotransporter, sialin (membrane glycoprotein HP59, Contig 6465), as well as a non-specific monocarboxylate carbohydrate transporter (CV455491). The former is involved in monosaccharide import across the lysosomal membrane and may function in the clearance of free cytosolic oligosaccharides derived from the breakdown of glycoproteins and other catabolic products (Fu et al., 2001; Winchester, 2001).

\subsubsection{Lipids}

Some 22 midgut-specific transcripts were identified that have putative functions in lipid metabolism and represent the largest subset of this class for all comparisons (Table 2). It has been suggested that secreted phospholipases may play a role in hemolysis of the ingested blood cells (Zhu et al., 1997). In this regard, putative lipases (Contig 2297, TC17614 and Contig 1290) were highly up- 
regulated in the midgut (Supplementary Table S4). Additional novel lipid carrier proteins were identified, including a carrier protein apolipophorin (Contig 156) with the highest $\log _{2}$ fold expression of midgut-specific transcripts (5.59) (Supplementary Table S4). This glycoprotein is involved in the transport of various lipids in the hemolymph, as well as heme (Duncan et al., 1999; Weers et al., 2006). A related transcript involved in oogenesis as a yolk protein precursor, vitellogenin (Contig 8127), was also identified (Supplementary Table S4). This protein has been identified in the midgut and fat body of Haemaphysalis longicornis and has been shown to play a role in heme sequestration (Thompson et al., 2007; Boldbaatar et al., 2010). Vitellogenin was also found to be regulated in response to ubiquitin-63E knockdown in gene expression microarrays of female $R$. microplus ticks (Lew-Tabor et al., 2011). Several proteins sharing sequence similarities to the Niemann-Pick C family proteins (NPC1 and 2) from hard and soft ticks were highly expressed in midgut (TC17851, Contig 1508, CV443743 and Contig 727). These proteins have been proposed to be involved in intracellular cholesterol cycling and have been identified from the midgut of $D$. variabilis and I. ricinus (Vanier et al., 2004; Anderson et al., 2008; Horácková et al., 2010). A unique cytosolic fatty acid-binding protein (Contig 4249), not previously described for $R$. microplus, was also highly up-regulated and may play a role in intracellular transport of long-chain fatty acids,

Other midgut-specific proteins with putative functions in lipid degradation (Contig 7995, TC22152 and Contig 1729), as well as fatty acid biosynthesis (Contig 2638, Contig 6832, Contig 6561, Contig 2086, Contig 2302, Contig 3708 and Contig 2303) were identified (Supplementary Table S4). Of these proteins, prosaposin (Contig 1729) and ATP-dependent CoA ligase (Contig 3708) have been identified previously from the mialome of $D$. variabilis but not from $R$. microplus midgut (Anderson et al., 2008).

\subsubsection{Other midgut-specific proteins}

During digestion a large amount of heme is produced and as a result high levels of cytotoxic iron are released into the midgut. Furthermore, $R$. microplus lacks the biosynthetic pathway for heme 
production and therefore acquires it from the blood meal (Braz et al., 1999). A novel ferritin transcript (Contig 3919), similar to that of $I$. ricinus, was identified among the unique up-regulated midgut transcripts (Supplementary Table S4). Ferritin is a cytosolic storage protein that sequesters ferric iron for heme and iron metabolism. This protein has been cloned from the gut of O. moubata and I. ricinus (Kopácek et al., 2003). More recently, ferritin has been cloned from R. microplus and pilot trials in rabbits using recombinant protein showed promising efficacy as a vaccine target (Hajdusek et al., 2010).

Some 15 putative signal transduction transcripts were highly up-regulated (Supplementary Table S4). These included two membrane associated proteins that are uniquely expressed in midgut tissues, namely ATAQ (Contig 3639) and Bm86 (Contig 8501) (Supplementary Table S4). Bm86 and ATAQ are both glycoproteins of unknown function containing epidermal growth factor domains that have been localized to the midgut tissues of a number of tick species (Nijhof et al., 2010). To date, Bm86 remains the only protein antigen that has been successfully used in the production of a commercial tick vaccine. Additional acetylcholinesterases (Contig 4226 and Contig 8297) were identified that have been characterized for $R$. microplus and implicated in acquiring acaricide resistance (Baxter and Barker, 1998; Guerrero et al., 2012). A calmodulin binding protein (Contig473) and a putative GTP-binding protein (Rab) (Contig 2938), were also highly up-regulated in midgut tissues (Supplementary Table S4). Calmodulin proteins have been identified from midgut tissues of $D$. variabilis and are well known effectors in signal transduction mechanisms, affecting a number of cellular processes including membrane trafficking mediated by Rab GTPases (Stenmark and Olkkonen, 2001; Anderson et al., 2008). These proteins have also been suggested to play a role in smooth muscle contraction of the midgut during feeding.

\subsection{Unique transcripts highly regulated in adult female ovaries}

Transcriptional analysis of $R$. microplus female ovaries identified 417 unique transcripts (Tables 1, 2, Supplementary Table S5). The major functional classes that could be identified according 
to KOG classification related to transcription ( $7.4 \%)$, protein modification and turnover $(6.7 \%)$, signal transduction $(4.6 \%)$ and cell cycle control $(3.6 \%)$, while approximately $52.8 \%$ of transcripts could not be functionally assigned (Fig. 1D). A total of 72 annotatable transcripts were highly up-regulated (Tables1, 2, Supplementary Table S5).

\subsubsection{Chromatin structure, replication, cell cycle control and signal transduction}

Following DNA replication (or $S$ phase), the meiotic cell cycle development occurs in two consecutive cell divisions called M phases (Nebreda and Ferby, 2000). Transcriptional analysis identified some highly up-regulated ovary-specific transcripts that are involved in chromosomal organization. These include several nucleosome core histones of the H2A (TC21623, Contig 4221 and Contig 2123), H3 (Contig 6410, Contig 5900) and H4 (Contig 5362) families, a putative maintenance of chromosomes (SMC) ATPase (CV457670) and microcephalin (Contig 6899) (Supplementary Table S5). These proteins are involved in maintenance of the nuclear architecture, especially during DNA replication (S phase) in other organisms such as Drosophila (Kornberg and Lorch, 1999; Hirano, 2005). Two groucho-related transducer proteins (CK189050 and Contig 4005) were identified, presumably involved in transcriptional regulation by interaction with the histone core in response to cyclin-dependent kinases (Turki-Judeh and Courey, 2012). In this regard, a putative cyclin-dependent kinase (CV446249) was also identified (Supplementary Table S5).

Various proteins serve as checkpoints during cell division and tightly control progression through the cell cycle. Ovary-specific transcripts such as a B-type cyclin (CV451547), a serine/threonine protein kinases (Contig 347) and a polo-like protein kinase (Contig 4236), as well as a putative coiled-coil domain-containing protein (Spindly) (Contig 6020) were up-regulated (Supplementary Table S5). Cyclins play key roles in cell cycle development during early mitotic divisions in Drosophila, where B-type cyclins are involved in activation of several key proteins involved in spindle formation and progression through metaphase and anaphase (McCleland et al., 2009; Yoshitome et al., 2012). In this regard, the related protein, Spindly, is involved in chromosome 
segregation during mitosis/meiosis by mediating the recruitment of dynactin to the kinetochore during spindle formation (Chan et al., 2009). Aurora kinases and polo-like kinases can associate with the centrosome and are involved in regulation of spindle formation via activation of proteins such as Spindly and histone phosphorylation during oogenesis (Ding et al., 2011; Song et al., 2012; Yoshitome et al., 2012). An additional putative repressor of embryonic development via the Wnt/beta-catenin pathway, protein bicaudal C homolog 1 (Contig 383), was also found to be highly up-regulated (Supplementary Table S5).

\subsubsection{Transcription and control}

Transcriptional initiation and control can be achieved via expression of ovary-specific transcription factors and degradation of the mRNA by the endogenous RNAi machinery, respectively. In this regard, zinc-finger proteins represent the largest family of DNA-binding transcription factors present in a number of bilaterians, including Homo sapiens, Drosophila melanogaster, Caenorhabitis elegans and more recently in the arthropod, Daphnia pulex (Seetharam et al., 2010). Numerous novel zinc-finger proteins, such as C2H2-type zinc-finger proteins (CV457291, Contig 4738 and CK173279), were identified that were highly up-regulated in ovaries (Supplementary Table S5). Putative RNA processing proteins involved in post-transcriptional gene regulation were also identified as highly upregulated in ovaries, similar to transcripts previously identified from $R$. microplus ESTs (Kurscheid et al., 2009) (Supplementary Table S5). In addition, a putative proliferating cell nuclear antigen (PCNA)associated factor (Contig 5833) and a DNA excision repair protein (Contig 7899) were identified (Supplementary Table S5). These proteins are important processing factors involved in postreplication repair (Essers et al., 2005).

\subsubsection{Metabolism and other ovary-specific proteins}

Only a few highly up-regulated transcripts have been identified that are involved in amino acid, carbohydrate and lipid metabolism (Supplementary Table S5). These include several ovary-specific 
proteases with limited description in R. microplus. Firstly, is an astacin (Contig 1441) that has been shown to be expressed in R. microplus female reproductive tissues (Barnard et al., 2012). Secondly, are novel metalloproteases such as the thrombospondin type-1 domain-containing (ADAMTS)-like protein (Contig 8445) suggested to play a role in modulating microfibril functions, as well as a neprilysin (Contig 6628) similar to Drosphila spp. neprilysin 2 that has been suggested to play a role in signaling during embryogenesis (Bland et al., 2007; Bader et al., 2012). Thirdly, a cathepsin L1 cysteine peptidase (Contig 1209) was identified that has only been described in midgut tissues of $R$. microplus (Kongsuwan et al., 2010). Finally, together with other serine proteases, a transcript encoding putative oviductin (Contig 6991) was up-regulated in ovaries (Supplementary Table S5). This secreted protease is involved in egg envelope glycoprotein alteration for fertilization in the oviduct epithelia of amphibians (Hiyoshi et al., 2002). However, its role in tick oogenesis remains to be elucidated.

Two novel up-regulated carbohydrate metabolizing enzymes were identified: an alpha 1,3fucosyltransferase enzyme (Contig 2393) and an N-acetyllactosaminide beta-1,3-Nacetylglucosaminyltransferase (Contig 46A). These enzymes are involved in N-glycan synthesis of glycoprotein moieties and unsaturated fatty acids biosynthesis, respectively (Fabini et al., 2001; Okajima et al., 2008).

During tick oogenesis and egg maturation, major egg yolk proteins (vitellogenin) are produced by the fat body and the midgut (Tufail and Takeda, 2009; Boldbaatar et al., 2010). These hemoglycolipoproteins are taken up together with lipid-binding lipophorin into the ovaries by lowdensity lipoprotein receptors via receptor-mediated endocytosis (Tufail and Takeda, 2009). A putative low-density lipoprotein receptor-related protein (Contig 276) was highly up-regulated in ovaries (Supplementary Table S5). These results correlated well with transcripts involved in lipid transport that were up-regulated in midguts.

Several transporter proteins were identified that were highly up-regulated in ovaries and included two novel ABC transporters (Contig 2240 and Contig 1691) (Supplementary Table S5). ABC 
transporters are proteins involved in detoxification processes and have been identified from midgut tissues of female $R$. microplus, where transporter activity has been implicated in acaricide resistance (Pohl et al., 2011, 2012).

\subsection{Gene expression of transcripts occurring in all adult female tissues during feeding}

A key objective of this study was to identify proteins and potential biochemical processes that are shared between the different adult tissues. Following transcriptional analysis, 588 expressed transcripts were identified that were shared among all of the tissues tested (Fig. 1A, Tables 1, 2, Supplementary Table S2). Considering transcripts that have a minimum intensity above the threshold of 1,000 ( $\mathrm{M}$ value > 0 ), only $4.4 \%$ of the total transcripts used in microarray analysis showed transcriptional regulation (Table 1). Of these transcripts, $38.8 \%$ could not be functionally annotated (Fig. 1E). The major functional classes that could be identified involved protein modification and turnover (11.2\%), translation, ribosomal structure and biogenesis $(10.2 \%)$, as well as RNA processing (6.3\%) and intracellular trafficking and transport (5.8\%) (Fig. 1E). Only 90 annotatable transcripts with a minimum two-fold threshold intensity (Cy5 > 2,000) were identified (Tables 1, 2, Supplementary Table S2).

\subsubsection{Metabolism, energy production and transport}

Shared transcripts were identified that are related to amino acid, nucleotide, carbohydrate and lipid metabolism (Supplementary Table S2). These transcripts include several putative metabolic enzymes: phosphoglycerate dehydrogenases (Contig 387 and Contig 8440) involved in L-serine biosynthesis, GDP-L-fucose synthase (Contig 4405) and GDP-mannose 4,6 dehydratase (Contig 497) involved GDP-L-fucose biosynthesis and polysaccharide breakdown, a glucan 1,3-alpha-glucosidase (Contig 835) involved in glycan metabolism for glycoprotein synthesis, a tau-protein kinase (Contig 8022) involved in glycogen metabolism, a 3-hydroxyacyl-CoA dehydrogenase (Contig 1246) involved in cholesterol degradation and fatty acid beta-oxidation, acetyl-CoA C-acetyltransferases (Contig 8253 
and Contig 2916) involved in ketone body metabolism and finally a dUTP diphosphatase (Contig 8942) involved in the biosynthesis of dUMP. The large number of transcripts identified, unique or shared, across all tissues involved in carbohydrate and lipid metabolism, may imply that metabolic energy is mainly derived from carbohydrate and fatty acid sources.

Transcripts related to mitochondrial transport and energy metabolism were identified and these include components associated with oxidative phosphorylation: a cytochrome c oxidase (Contig 2837), $\mathrm{NAD}(\mathrm{P})(+)$ transhydrogenase (Contig 4420) and a ADP/ATP translocase 2 (Contig 4681). A putative isocitrate dehydrogenase (Contig 424), a component of the citric acid cycle, was also identified as a shared transcript (Supplementary Table S2). Cytochrome c oxidases and other associated proteins involved with energy metabolism have been identified from the mialome of $D$. variabilis, as well as sialomes of both hard and soft tick species (Anderson et al., 2008; Francischetti et al., 2010; Kongsuwan et al., 2010).

A number of shared transcripts encoding components of the ubiquitin/proteasome pathway, involved in the degradation of unneeded or damaged proteins, were identified: two proteins involved in ubiquitination of target proteins for degradation, a RING-box protein 1A (Contig 5214) and a ubiquitinprotein ligase (Contig 8175), as well as several subunits of the proteasome endopeptidase complex (Contig 2948, Contig 903 and Contig 887). Subunits of the proton-pumping V-ATPase complex were also identified (Contig 8631, Contig 2275 and Contig 8181), which are involved in acidification of lysosomal lumen necessary for digestion of macromolecules or exocytosis-mediated secretion (Bowman and Sauer, 2004; Mindell, 2012). Similar transcripts have only been identified from comparative sialome data for R. microplus (Francischetti et al., 2010).

\subsubsection{Transcription, translation and protein synthesis}

Following transcriptional analysis, some key shared transcripts were identified that function in gene expression and control (Supplementary Table S2). Of these, some novel transcripts involved in control of transcription activation that were shared between female tissues include: a RuvB-like DNA 
helicase (Contig 5083) that is part of the NuA4 histone acetyltransferase complex involved in transcription activation via modification of core histones $\mathrm{H} 4$ and H2A (Doyon et al., 2004; Lu et al., 2009), a DPY30 domain-containing protein (Contig 346) that is part of the mixed lineage leukemia protein -1 (MLL1) core complex involved in methylation of histone H3 (Vardanyan et al., 2008; Patel et al., 2011), as well as an arginine $\mathrm{N}$-methyltransferase (Contig 137) that is the main enzyme involved in mono-methylation of histone H4 (Boulanger et al., 2004; Bachand, 2007). Additional transcription factors BTF3 (Contig 1649) and putative X-box-binding protein 1 (Contig 6772) were identified (Liou et al., 1990; Zheng et al., 1990). These proteins have not been characterized for $R$. microplus.

Alternative splicing of mRNA is regarded as one of the main steps in regulation of gene expression and five transcripts encoding splicing factors of the SR family (Contig 825, Contig 8997, Contig 1956, Contig 5832, Contig 8773 and Contig 5369) and a thioredoxin-like protein (Contig 5832) were identified (Supplementary Table S2). These proteins are essential in constitutive pre-mRNA splicing and can also act as regulators in other aspects of mRNA metabolism (Long and Caceres, 2009). A related U2 small nuclear ribonucleoprotein (snRNP) (Contig 1192) which was also identified is a component of the spliceosome complex (Supplementary Table S2). Similar proteins have only been identified from sialome data that include transcripts from R. microplus (Francischetti et al., 2010)

Assembly of a functional ribosome is vital for successful protein synthesis. In this regard, a number of ribosome associated proteins were identified that included components of the 40S (Contig 7181 and EW680164.1) and 60S (Contig 1238, Contig 3228, EW680050.1, Contig 6473, Contig 1078, Contig 9000, CK177858 and Contig 7496) ribosomal subunits, as well as the 29S (TC20332) and 39S (Contig 2946) mitochondrial ribosomal subunits. Additional transcripts encoding subunits of the H/ACA small nucleolar ribonucloeprotein complex (Contig 1577) involved in pseudouridylation of rRNA and the eukaryotic translation initiation factor 3 complex (Contig 2574) that associates with the $40 \mathrm{~S}$ ribosomal subunit for initiation of translation, were also found to be shared (Pestova et al., 2001; Watkins and Bohnsack, 2012). These proteins have been identified from sialome and midgut proteome data of $R$. microplus (Francischetti et al., 2010; Kongsuwan et al., 2010) 
Proper folding of translated proteins is predominantly mediated by chaperones of which the alpha subunit of the nascent polypeptide-associated complex (Contig 8810) was identified from shared transcripts (Supplementary Table S2). This complex functions as a molecular chaperone that generally associates with newly synthesized nascent polypeptides from the ribosomes to prevent inappropriate interactions with cytosolic proteins such as signal recognition particles (SRP) (Preissler and Deuerling, 2012). In this regard, a putative SRP14 protein (Contig 4224) was identified from the shared tissue transcripts (Supplementary Table S2). These proteins are involved in polypeptide translocation to the endoplasmic reticulum for intracellular trafficking (Preissler and Deuerling, 2012). Additional shared molecular chaperones (Contig 5499, Contig 210, Contig 2441, Contig 2805, Contig 790, Contig 2759 and Contig 2634) were identified (Supplementary Table S2). Similar chaperones have been identified in other ixodid ticks, as well as sialomes, transcriptome and midgut proteome data for R. microplus (Guilfoile et al., 2004; Anderson et al., 2008; Francischetti et al., 2010; Kongsuwan et al., 2010; Rodriguez-Valle et al., 2010). A putative mitochondrial chaperone involved in import and insertion of inner membrane proteins, TIM13 (Contig 6255), was also identified as a shared transcript (Supplementary Table S2).

\subsection{Tick biology and future perspectives}

Transcriptional profiling of feeding adult $R$. microplus female tissues identified distinct subsets of genes that aid in blood meal acquisition (salivary glands), digestion (midgut) and reproduction (ovaries) (Table 2, Fig. 2). For salivary glands, a large repertoire of anti-hemostatics and immunomodulatory transcripts maintain the fluidity of the blood meal, while additional secreted proteases aid in blood pool formation and pre-digestion of the blood meal prior to ingestion. The midgut in turn is highly specialized to break down the components of the blood meal with wide arrays of proteases involved in digestion, where additional metabolic enzymes and transporters enable the engorging female to acquire the necessary nutrients in preparation for reproduction. Some additional highly up-regulated transcripts are also involved in alleviation of oxidative stress, defense against 
microbial invasion and host immune responses, as well as maintenance of blood meal fluidity via anticoagulants. As the female prepares for egg production, unique genes are highly up-regulated to control cell cycle development, DNA replication, post-transcriptional and post-translational modification. Some transcripts related to metabolism, transport and signaling were also differentially expressed.

Global comparison of transcripts shared between all tissues revealed a broader functional distribution (according to KOG annotation) than any single tissue comparison (Table 2). These include components involved in protein, carbohydrate and lipid metabolism necessary for biosynthetic pathways and energy production that indicate fundamental processes that are ubiquitous in all tissues during feeding. Notable are transcripts involved in signal transduction events that control the cell cycle, transcription and translation, making them an important component of basic tissue biology (Fig. 2).

As is the case with other comparative studies, numerous genes that were expressed in $R$. microplus female tissues during feeding could not be functionally annotated. Further similarity searches against the Ixodes scapularis genome database could not confer more informative annotation of unknown genes, highlighting the uniqueness of these transcripts (Hill and Wikel, 2005). Moreover, the vast majority of the predicted genes currently available for R. microplus in the BmiGI (v2.1) and the Cattle Tick sequence databases remain un-annotated (Wang et al., 2007; Bellgrad et al., 2012). Therefore, a meta-analysis approach that combines all available sequence databases (nucleotide, protein and structural) and involves extensive manual curation is needed. Such an approach has been successfully employed in the annotation of various tick sialomes (Francischetti et al., 2010). However, a unified nomenclature for sequence annotation is necessary to avoid confusion between similar entries. In this study, final annotation was based on reviewed sequences published in the Uniprot protein and Baunschweig enzyme (BRENDA) databases (Apweiler et al., 2011; Scheer et al., 2011). A central database containing all available tick sequences (Genome, ESTs, transcriptome, sialome and mialome) would also simplify comparative analysis but is still lacking. In this regard, the recently established Cattle Tick Database could become an invaluable resource, as the basis for a 
systematic attempt at annotating the full complement of genes and proteins of $R$. microplus (Bellgard et al., 2012).

Application of high-throughput techniques such as deep RNA sequencing (RNA-seq), as well as interactome analysis, will enable verification of open reading frames and aid in functional annotation of transcripts that share little to no sequence identity with other organisms (Brückner et al., 2009; Wang et al., 2009).

In conclusion, a catalogue of tissue-specific and shared genes was identified in major tissues involved in feeding and reproduction of adult $R$. microplus females using available sequence data and transcriptome analysis. This study presented here is, to our knowledge, the first global transcriptomic analysis via DNA microarrays of $R$. microplus female tissues and represents an additional resource that will be further exploited to study proteins and pathways that may be useful for future tick control.

\section{Acknowledgements}

This work was funded by the Red Meat Research Development Trust, University of Pretoria Research Development Programme and the Technology and Human Resources for Industry Programme, South Africa. Additional funding and student support was obtained from the National Research Foundation of South Africa. We would also like to thank Mrs. Santa Meyer and Dr. Tamsyn Pulker (University of Pretoria Biomedical Research Center) for cattle management, Prof Fourie Joubert (University of Pretoria, Computational Biology Unit) for bioinformatic support, as well as Prof. Dave Berger (University of Pretoria Department of Plant Science and the ACGT Microarray Facility) for advice during design the of this study. 


\section{References}

Anatriello, E., Ribeiro, J.M., de Miranda-Santos, I.K., Brandão, L.G., Anderson, J.M., Valenzuela, J.G., Maruyama, S.R., Silva, J.S., Ferreira, B.R., 2010. An insight into the sialotranscriptome of the brown dog tick, Rhipicephalus sanguineus. BMC Genomics. 11, 450.

Anderson, J.M., Sonenshine, D.E., Valenzuela, J.G., 2008. Exploring the mialome of ticks: an annotated catalogue of midgut transcripts from the hard tick, Dermacentor variabilis (Acari:Ixodidae). BMC Genomics. 9, 552.

Apweiler, R., Jesus Martin, M., O'onovan, C., Magrane, M., Alam-Faruque, Y., Antunes, R., Barrera Casanova, E., Bely, B., Bingley, M., Bower, L., Bursteinas, B., Mun Chan, W., Chavali, G., Da Silva, A., Dimmer, E., Eberhardt, R., Fazzini, F., Fedotov, A., Garavelli, J., Castro, L.G., Gardner, M., Hieta, R., Huntley, R., Jacobsen, J., Legge, D., Liu, W., Luo, J., Orchard, S., Patient, S., Pichler, K., Poggioli, D., Pontikos, N., Pundir, S., Rosanoff, S., Sawford, T., Sehra, H., Turner, E., Wardell, T., Watkins, X., Corbett, M., Donnelly, M., van Rensburg, P., Goujon, M., McWilliam, H., Lopez, R., Xenarios, I., Bougueleret, L., Bridge, A., Poux, S., Redaschi, N., Argoud-Puy, G., Auchincloss, A., Axelsen, K., Baratin, D., Blatter, M.C., Boeckmann, B., Bolleman, J., Bollondi, L., Boutet, E., Braconi Quintaje, S., Breuza, L., deCastro, E., Cerutti, L.,

Coudert, E., Cuche, B., Cusin, I., Doche, M., Dornevil, D., Duvaud, S., Estreicher, A., Famiglietti, L., Feuermann, M., Gehant, S., Ferro, S., Gasteiger, E., Gerritsen, V., Gos, A., Gruaz-Gumowski, N., Hinz, U., Hulo, C., Hulo, N., James, J., Jimenez, S., Jungo, F., Kappler, T., Keller, G., Lara, V., Lemercier, P., Lieberherr, D., Martin, X., Masson, P., Moinat, M., Morgat, A., Paesano, S., Pedruzzi, I., Pilbout, S., Pozzato, M., Pruess, M., Rivoire, C., Roechert, B., Schneider, M., Sigrist, C., Sonesson, K., Staehli, S., Stanley, E., Stutz, A., Sundaram, S., Tognolli, M., Verbregue, L., Veuthey, A.L., Wu, C.H., Arighi, C.N., Arminski, L., Barker, W.C., Chen, C., Chen, Y., Dubey, P., Huang, H., Kukreja, A., Laiho, K., Mazumder, R., McGarvey, P., Natale, D.A., Natarajan, T.G., Roberts, N.V., Suzek, B.E., Vinayaka, C., Wang, 
Q., Wang, Y., Yeh, L.S., Zhang, J., 2011. Reorganizing the protein space at the Universal Protein Resource (UniProt). Nucl. Acids Res., 40(Database issue), D71-75.

Bachand, F., 2007. Protein arginine methyltransferases: from unicellular eukaryotes to humans. Eukaryot. Cell. 6, 889-898.

Bader, H.L., Wang, L.W., Ho, J.C., Tran, T., Holden, P., Fitzgerald, J., Atit, R.P., Reinhardt, D.P., Apte, SS., 2012. A disintegrin-like and metalloprotease domain containing thrombospondin type 1 motif-like 5 (ADAMTSL5) is a novel fibrillin-1-, fibrillin-2-, and heparin-binding member of the ADAMTS superfamily containing a netrin-like module. Matrix Biol. 31, 398-411.

Barnard, A.C., Nijhof, A.M., Gaspar, A.R., Neitz, A.W., Jongejan, F., Maritz-Olivier, C., 2012. Expression profiling, gene silencing and transcriptional networking of metzincin metalloproteases in the cattle tick, Rhipicephalus (Boophilus) microplus. Vet. Parasitol., 186, 403-414.

Batista, I.F., Chudzinski-Tavassi, A.M., Faria, F., Simons, S.M., Barros-Batestti, D.M., Labruna, M.B., Leão, L.I., Ho, P.L., Junqueira-de-Azevedo, I.L., 2008. Expressed sequence tags (ESTs) from the salivary glands of the tick Amblyomma cajennense (Acari:Ixodidae). Toxicon. 51, 823-834.

Baxter, G.D., Barker, S.C., 1998. Acetylcholinesterase cDNA of the cattle tick, Boophilus microplus: characterisation and role in organophosphate resistance. Insect Biochem. Mol. Biol. 28, 581589.

Bellgard, M.I., Moolhuijzen, P.M., Guerrero, F.D., Schibeci, D., Rodriguez-Valle, M., Peterson, D.G., Dowd, S.E., Barrero, R., Hunter, A., Miller, R.J., Lew-Tabor, A.E., 2012. CattleTickBase: an integrated Internet-based bioinformatics resource for Rhipicephalus (Boophilus) microplus. Int J Parasitol. 42, 161-169.

Bland, N.D., Thomas, J.E., Audsley, N., Shirras, A.D., Turner, A.J., Isaac, R.E., 2007. Expression of NEP2, a soluble neprilysin-like endopeptidase, during embryogenesis in Drosophila melanogaster. Peptides. 28, 127-135. 
Boldbaatar, D., Umemiya-Shirafuji, R., Liao, M., Tanaka, T., Xuan, X., Fujisaki, K., 2010. Multiple vitellogenins from the Haemaphysalis longicornis tick are crucial for ovarian development. J. Insect Physiol. 56, 1587-1598.

Boulanger, M.C., Miranda, T.B., Clarke, S., Di Fruscio, M., Suter, B., Lasko, P., Richard, S., 2004. Characterization of the Drosophila protein arginine methyltransferases DART1 and DART4. Biochem J. 379(Pt 2), 283-289.

Bowman, A.S., Sauer, J.R., 2004. Tick salivary glands: function, physiology and future. Parasitology 129 (Suppl), S67-S81.

Braz, G.R., Coelho, H.S., Masuda, H., Oliveira, P.L., 1999. A missing metabolic pathway in the cattle tick Boophilus microplus. Curr. Biol. 9, 703-706.

Brückner, A., Polge, C., Lentze, N., Auerbach, D., Schlattner, U., 2009. Yeast two-hybrid, a powerful tool for systems biology. Int J Mol Sci. 10, 2763-2788.

Buresova, V., Hajdusek, O., Franta, Z., Sojka, D., Kopacek, P., 2009. IrAM-An alpha2-macroglobulin from the hard tick Ixodes ricinus: characterization and function in phagocytosis of a potential pathogen Chryseobacterium indologenes. Dev Comp Immunol. 33, 489-498.

Campbell, E.M., Burdin, M., Hoppler, S., Bowman, A.S., 2010. Role of an aquaporin in the sheep tick Ixodes ricinus: assessment as a potential control target. Int J Parasitol. 40, 15-23.

Chalaire, K.C., Kim, T.K., Garcia-Rodriguez, H., Mulenga, A., 2011. Amblyomma americanum (L.) (Acari: Ixodidae) tick salivary gland serine protease inhibitor (serpin) 6 is secreted into tick saliva during tick feeding. J Exp Biol. 214(Pt 4), 665-673.

Chan, Y.W., Fava, L.L., Uldschmid, A., Schmitz, M.H., Gerlich, D.W., Nigg, E.A., Santamaria, A., 2009. Mitotic control of kinetochore-associated dynein and spindle orientation by human Spindly. J. Cell Biol. 185, 859-874.

Citelli, M., Lara, F.A., da Silva Vaz, I. Jr, Oliveira, P.L., 2007. Oxidative stress impairs heme detoxification in the midgut of the cattle tick, Rhipicephalus (Boophilus) microplus. Mol. Biochem. Parasitol. 151, 81-88. 
Cruz, C.E., Fogaça, A.C., Nakayasu, E.S., Angeli, C.B., Belmonte, R., Almeida, I.C., Miranda, A., Miranda, M.T., Tanaka, A.S., Braz, G.R., Craik, C.S., Schneider, E., Caffrey, C.R., Daffre, S., 2010. Characterization of proteinases from the midgut of Rhipicephalus (Boophilus) microplus involved in the generation of antimicrobial peptides. Parasit. Vectors. 3, 63.

de la Fuente, J., Almazán, C., Canales, M., Pérez de la Lastra, J.M., Kocan, K.M., Willadsen, P., 2007. A ten-year review of commercial vaccine performance for control of tick infestations on cattle. Anim. Health Res. Rev. 8, 23-28.

de La Fuente, J., Rodríguez, M., García-García, J.C., 2000. Immunological control of ticks through vaccination with Boophilus microplus gut antigens. Ann N Y Acad Sci. 916, 617-621.

de Miranda Santos, I.K.F., Valenzuela, J.G., Ribeiro, J.M., de Castro, M., Costa, J.N., Costa, A.M., da Silva, E.R., Neto, O.B., Rocha, C., Daffre, S., Ferreira, B.R., da Silva, J.S., Szabó, M.P., Bechara, G., 2004. Gene discovery in Boophilus microplus, the cattle tick: the transcriptomes of ovaries, salivary glands, and hemocytes. Ann. N.Y. Acad. Sci. 1026, 242-246.

Ding, J., Swain, J.E., Smith, G.D., 2011. Aurora kinase-A regulates microtubule organizing center (MTOC) localization, chromosome dynamics, and histone-H3 phosphorylation in mouse oocytes. Mol. Reprod. Dev. 78, 80-90.

Doyon, Y., Selleck, W., Lane, W.S., Tan, S., Côté, J., 2004. Structural and functional conservation of the NuA4 histone acetyltransferase complex from yeast to humans. Mol Cell Biol. 24, 18841896.

Duncan, T., Osawa, Y., Kutty, R.K., Kutty, G., Wiggert, B., 1999. Heme-binding by Drosophila retinoidand fatty acid-binding glycoprotein (RFABG), a member of the proapolipophorin gene family. J. Lipid Res. 40, 1222-1228.

Essers, J., Theil, A.F., Baldeyron, C., van Cappellen, W.A., Houtsmuller, A.B., Kanaar, R., Vermeulen, W., 2005. Nuclear dynamics of PCNA in DNA replication and repair. Mol. Cell Biol. 25, 93509359. 
Fabini, G., Freilinger, A., Altmann, F., Wilson, I.B., 2001. Identification of core alpha 1,3-fucosylated glycans and cloning of the requisite fucosyltransferase cDNA from Drosophila melanogaster. Potential basis of the neural anti-horseadish peroxidase epitope. J. Biol. Chem. 276, 2805828067.

Fogaça, A.C., Almeida, I.C., Eberlin, M.N., Tanaka, A.S., Bulet, P., Daffre, S., 2006. Ixodidin, a novel antimicrobial peptide from the hemocytes of the cattle tick Boophilus microplus with inhibitory activity against serine proteinases. Peptides. 27, 667-674.

Fogaça, A.C., Lorenzini, D.M., Kaku, L.M., Esteves, E., Bulet, P., Daffre, S., 2004. Cysteine-rich antimicrobial peptides of the cattle tick Boophilus microplus: isolation, structural characterization and tissue expression profile. Dev. Comp. Immunol. 28, 191-200.

Francischetti, I.M., Sa-Nunes, A., Mans, B.J., Santos, I.M., Ribeiro, J.M., 2010. The role of saliva in tick feeding. Front Biosci. 14, 2051-2088.

Fu, C., Bardhan, S., Cetateanu, N.D., Wamil, B.D., Wang, Y., Yan, H.P., Shi, E., Carter, C., Venkov, C., Yakes, F.M., Page, D.L., Lloyd, R.S., Mernaugh, R.L., Hellerqvist, C.G., 2001. Identification of a novel membrane protein, HP59, with therapeutic potential as a target of tumor angiogenesis. Clin Cancer Res. 7, 4182-4194.

Gontijo, N.F., Almeida-Silva, S., Costa, F.F., Mares-Guia, M.L., Williams, P., Melo, M.N., 1998. Lutzomyia longipalpis: $\mathrm{pH}$ in the gut, digestive glycosidases, and some speculations upon Leishmania development. Exp. Parasitol. 90, 212-219.

Guerrero, F.D., Lovis, L., Martins, J.R., 2012. Acaricide resistance mechanisms in Rhipicephalus (Boophilus) microplus. Rev Bras Parasitol Vet. 21, 1-6.

Guerrero, F.D., Nene, V.M., George, J.E., Barker, S.C., Willadsen, P., 2006. Sequencing a new target genome: the Boophilus microplus (Acari:Ixodidae) genome project. J. Med. Entomol. 43, 9-16.

Guilfoile, P.G., Packila, M., 2004. Identification of four genes expressed by feeding female Ixodes scapularis, including three with sequence similarity to previously recognized genes. Exp. Appl. Acarol. 32, 103-110. 
Guo, Y., Ribeiro, J.M., Anderson, J.M., Bour, S., 2009. dCAS: a desktop application for cDNA sequence annotation. Bioinformatics. 25, 1195-1196.

Hajdusek, O., Almazán, C., Loosova, G., Villar, M., Canales, M., Grubhoffer, L., Kopacek, P., de la Fuente, J., 2010. Characterization of ferritin 2 for the control of tick infestations. Vaccine. 28, 2993-2998.

Hannun, Y.A., Obeid, L.M., 2008. Principles of bioactive lipid signalling: lessons from sphingolipids. Nat Rev Mol Cell Biol. 9, 139-150.

Hellemans, J., Mortier, G., De Paepe, A., Speleman, F., Vandesompele, J., 2007. qBase relative quantification framework and software for management and automated analysis of real-time quantitative PCR data. Genome Biol. 8, R19.

Hill, C., Wikel, S.K., 2005. The Ixodes scapularis Genome Project:an opportunity for advancing tick research. Trends Parasitol. 21, 151-153.

Hirano, T., 2005. SMC proteins and chromosome mechanics:from bacteria to humans. Philos. Trans. R. Soc. Lond. B. Biol. Sci. 360, 507-514.

Hiyoshi, M., Takamune, K., Mita, K., Kubo, H., Sugimoto, Y., Katagiri, C., 2002. Oviductin, the oviductal protease that mediates gamete interaction by affecting the vitelline coat in Bufo japonicus: its molecular cloning and analyses of expression and posttranslational activation. Dev. Biol. 243, 176-184.

Horácková, J., Rudenko, N., Golovchenko, M., Grubhoffer, L., 2010. Der-p2 (Dermatophagoides pteronyssinus) allergen-like protein from the hard tick Ixodes ricinus - a novel member of ML (MD-2-related lipid-recognition) domain protein family. Parasitology. 137, 1139-1149.

Horn, M., Nussbaumerová, M., Sanda, M., Kovárová, Z., Srba, J., Franta, Z., Sojka, D., Bogyo, M., Caffrey, C.R., Kopácek, P., Mares, M., 2009. Hemoglobin digestion in blood-feeding ticks: mapping a multipeptidase pathway by functional proteomics. Chem. Biol. 16, 1053-1063. 
Isaac, R.E., Ekbote, U., Coates, D., Shirras, A.D., 1999. Insect angiotensin-converting enzyme. A processing enzyme with broad substrate specificity and a role in reproduction. Ann. NY Acad. Sci. 897, 342-347.

Jarmey, J.M., Riding, G.A., Pearson, R.D., McKenna, R.V., Willadsen, P., 1995. Carboxydipeptidase from Boophilus microplus: a "concealed" antigen with similarity to angiotensin-converting enzyme. Insect Biochem Mol Biol. 25, 969-974.

Johnson, S.W., Alhadeff, J.A., 1991. Mammalian alpha-L-fucosidases. Comp Biochem Physiol B. 99, 479-488.

Ju, T., Brewer, K., D'Souza, A., Cummings, R.D., Canfield, W.M., 2002. Cloning and expression of human core 1 beta1,3-galactosyltransferase. J Biol Chem. 277, 178-186.

Kongsuwan, K., Josh, P., Zhu, Y., Pearson, R., Gough, J., Colgrave, M.L., 2010. Exploring the midgut proteome of partially fed female cattle tick (Rhipicephalus (Boophilus) microplus). J. Insect Physiol. 56, 212-226.

Kopácek, P., Zdychová, J., Yoshiga, T., Weise, C., Rudenko, N., Law, J.H., 2003. Molecular cloning, expression and isolation of ferritins from two tick species--Ornithodoros moubata and Ixodes ricinus. Insect Biochem. Mol. Biol. 33, 103-113.

Kornberg, R.D., Lorch, Y., 1999. Twenty-five years of the nucleosome, fundamental particle of the eukaryote chromosome. Cell. 98, 285-294.

Kurscheid, S., Lew-Tabor, A.E., Rodriguez Valle, M., Bruyeres, A.G., Doogan, V.J., Munderloh, U.G., Guerrero, F.D., Barrero, R.A., Bellgard, M.I., 2009. Evidence of a tick RNAi pathway by comparative genomics and reverse genetics screen of targets with known loss-of-function phenotypes in Drosophila. BMC Mol. Biol. 10, 26.

Lew-Tabor, A.E., Kurscheid, S., Barrero, R., Gondro, C., Moolhuijzen, P.M., Rodriguez Valle, M., Morgan, J.A., Covacin, C., Bellgard, M.I., 2011. Gene expression evidence for off-target effects caused by RNA interference-mediated gene silencing of Ubiquitin-63E in the cattle tick Rhipicephalus microplus. Int. J. Parasitol. 41, 1001-1014. 
Li, A.Y., Chen, A.C., Miller, R.J., Davey, R.B., George, J.E.,2007. Acaricide resistance and synergism between permethrin and amitraz against susceptible and resistant strains of Boophilus microplus (Acari:Ixodidae). Pest Manag. Sci. 63, 882-889.

Lin, X., Söderhäll, I., 2011. Crustacean hematopoiesis and the astakine cytokines. Blood. 117, 64176424.

Liou, H.C., Boothby, M.R., Finn, P.W., Davidon, R., Nabavi, N., Zeleznik-Le, N.J., Ting, J.P., Glimcher, L.H., 1990. A new member of the leucine zipper class of proteins that binds to the HLA DR alpha promoter. Science. 247, 1581-1584.

Long, J.C., Caceres, J.F., 2009. The SR protein family of splicing factors: master regulators of gene expression. Biochem. J. 417, 15-27.

Lu, P.Y., Lévesque, N., Kobor, M.S., 2009. NuA4 and SWR1-C: two chromatin-modifying complexes with overlapping functions and components. Biochem. Cell Biol. 87, 799-815.

Lynen, G., Zeman, P., Bakuname, C., Di Giulio, G., Mtui, P., Sanka, P., Jongejan, F., 2008. Shifts in the distributional ranges of Boophilus ticks in Tanzania:evidence that a parapatric boundary between Boophilus microplus and B. decoloratus follows climate gradients. Exp. Appl. Acarol. 44, 147-164.

Macours, N., Poels, J., Hens, K., Francis, C., Huybrechts, R., 2004. Structure, evolutionary conservation, and functions of angiotensin- and endothelin-converting enzymes. Int. Rev. Cytol. 239, 47-97.

Madder, M., Thys, E., Geysen, D., Baudoux, C., Horak, I., 2007. Boophilus microplus ticks found in West Africa. Exp. Appl. Acarol. 43, 233-234.

Madder, M., Thys, E., Geysen, D., Baudoux, C., Horak, I., 2007. Boophilus microplus ticks found in West Africa. Exp Appl Acarol. 43, 233-234.

Mans, B.J., Andersen, J.F., Francischetti, I.M., Valenzuela, J.G., Schwan, T.G., Pham, V.M., Garfield, M.K., Hammer, C.H., Ribeiro, J.M., 2008. Comparative sialomics between hard and soft 
ticks:implications for the evolution of blood-feeding behaviour. Insect Biochem. Mol. Biol. 38, 42-58.

Maruyama, S.R., Anatriello, E., Anderson, J.M., Ribeiro, J.M., Brandão, L.G., Valenzuela, J.G., Ferreira, B.R., Garcia, G.R., Szabó, M.P., Patel, S., Bishop, R., de Miranda-Santos, I.K., 2010. The expression of genes coding for distinct types of glycine-rich proteins varies according to the biology of three metastriate ticks, Rhipicephalus (Boophilus) microplus, Rhipicephalus sanguineus and Amblyomma cajennense. BMC Genomics. 11, 363.

McCleland, M.L., Farrell, J.A., O'Farrell, P.H., 2009. Influence of cyclin type and dose on mitotic entry and progression in the early Drosophila embryo. J. Cell Biol. 184, 639-646.

McKenna, R.V., Riding, G.A., Jarmey, J.M., Pearson, R.D., Willadsen, P., 1998. Vaccination of cattle against the Boophilus microplus using a mucin-like membrane glycoprotein. Parasite Immunol. $20,325-336$.

Mercado-Curiel, R.F., Palmer, G.H., Guerrero, F.D., Brayton, K.A., 2011. Temporal characterisation of the organ specific Rhipicephalus microplus transcriptional response to Anaplasma marginale infection. Int. J. Parasitol. 41, 851-860.

Mindell, J.A., 2012. Lysosomal acidification mechanisms. Annu. Rev. Physiol. 74, 69-86.

Moolhuijzen, P.M., Lew-Tabor, A.E., Morgan, J.A., Valle, M.R., Peterson, D.G., Dowd, S.E., Guerrero, F.D., Bellgard, M.I., Appels, R., 2011. The complexity of Rhipicephalus (Boophilus) microplus genome characterised through detailed analysis of two BAC clones. BMC Res. Notes. 4, 254.

Nakajima, Y., van der Goes van Naters-Yasui, A., Taylor, D., Yamakawa, M., 2002. Antibacterial peptide defensin is involved in midgut immunity of the soft tick, Ornithodoros moubata. Insect. Mol. Biol. 11, 611-618.

Nebreda, A.R., Ferby, I., 2000. Regulation of the meiotic cell cycle in oocytes. Curr. Opin. Cell Biol. $12,666-675$. 
Nijhof, A.M., Balk, J.A., Postigo, M., Jongejan, F., 2009. Selection of reference genes for quantitative RT-PCR studies in Rhipicephalus (Boophilus) microplus and Rhipicephalus appendiculatus ticks and determination of the expression profile of Bm86. BMC Mol. Biol. 10, 112.

Nijhof, A.M., Balk, J.A., Postigo, M., Rhebergen, A.M., Taoufik, A., Jongejan, F., 2010. Bm86 homologues and novel ATAQ proteins with multiple epidermal growth factor (EGF)-like domains from hard and soft ticks. Int. J. Parasitol. 40, 1587-1597.

Okajima, T., Matsuura, A., Matsuda, T., 2008. Biological functions of glycosyltransferase genes involved in O-fucose glycan synthesis. J. Biochem. 144, 1-6.

Pagel Van Zee, J., Geraci, N.S., Guerrero, F.D., Wikel, S.K., Stuart, J.J., Nene, V.M., Hill, C.A., 2007. Tick genomics: the Ixodes genome project and beyond. Int. J. Parasitol. 37, 1297-1305.

Patel, A., Vought, V.E., Dharmarajan, V., Cosgrove, M.S., 2011. A novel non-SET domain multisubunit methyltransferase required for sequential nucleosomal histone $\mathrm{H} 3$ methylation by the mixed lineage leukemia protein-1 (MLL1) core complex. J. Biol. Chem. 286, 3359-3369.

Pestova, T.V., Kolupaeva, V.G., Lomakin, I.B., Pilipenko, E.V., Shatsky, I.N., Agol, V.I., Hellen, C.U., 2001. Molecular mechanisms of translation initiation in eukaryotes. Proc. Natl. Acad. Sci. USA. 98, 7029-7036.

Pitari, G., Malergue, F., Martin, F., Philippe, J.M., Massucci, M.T., Chabret, C., Maras, B., Duprè, S., Naquet, P., Galland, F., 2000. Pantetheinase activity of membrane-bound Vanin-1: lack of free cysteamine in tissues of Vanin-1 deficient mice. FEBS Lett. 483, 149-154.

Pohl, P.C., Klafke, G.M., Carvalho, D.D., Martins, J.R., Daffre, S., da Silva Vaz, I. Jr., Masuda, A., 2011. ABC transporter efflux pumps: a defense mechanism against ivermectin in Rhipicephalus (Boophilus) microplus. Int J Parasitol. 41, 1323-1333.

Pohl, P.C., Klafke, G.M., Júnior, J.R., Martins, J.R., da Silva Vaz, I. Jr., Masuda, A., 2012. ABC transporters as a multidrug detoxification mechanism in Rhipicephalus (Boophilus) microplus. Parasitol Res. 111, 2345-2351. 
Preissler, S., Deuerling, E., 2012. Ribosome-associated chaperones as key players in proteostasis. Trends Biochem. Sci. 37, 274-283.

Rajput, Z.I., Hu, S.H., Chen, W.J., Arijo, A.G., Xiao, C.W.,2006. Importance of ticks and their chemical and immunological control in livestock. J. Zhejiang Univ. Sci. B. 7, 912-921.

Ribeiro, J.M., Alarcon-Chaidez, F., Francischetti, I.M., Mans, B.J., Mather, T.N., Valenzuela, J.G., Wikel, S.K., 2006. An annotated catalog of salivary gland transcripts from Ixodes scapularis ticks. Insect Biochem. Mol. Biol. 36, 111-129.

Ribeiro, J.M., Anderson, J.M., Manoukis, N.C., Meng, Z., Francischetti, I.M., 2011. A further insight into the sialome of the tropical bont tick, Amblyomma variegatum. BMC Genomics. 12, 136.

Riding, G.A., Jarmey, J., McKenna, R.V., Pearson, R., Cobon, G.S., Willadsen, P., 1994. A protective "concealed" antigen from Boophilus microplus. Purification, localization, and possible function. J Immunol. 153, 5158-5166.

Rodriguez-Valle, M., Lew-Tabor, A., Gondro, C., Moolhuijzen, P., Vance, M., Guerrero, F.D., Bellgard, M., Jorgensen, W., 2010. Comparative microarray analysis of Rhipicephalus (Boophilus) microplus expression profiles of larvae pre-attachment and feeding adult female stages on Bos indicus and Bos taurus cattle. BMC Genomics 11, 437.

Saldivar, L., Guerrero, F.D., Miller, R.J., Bendele, K.G., Gondro, C., Brayton, K.A., 2008. Microarray analysis of acaricide-inducible gene expression in the southern cattle tick, Rhipicephalus (Boophilus) microplus. Insect Mol. Biol. 17, 597-606.

Saravanan, T., Weise, C., Sojka, D., Kopácek, P., 2003. Molecular cloning, structure and bait region splice variants of alpha2-macroglobulin from the soft tick Ornithodoros moubata. Insect Biochem Mol Biol. 33, 841-851.

Sasaki, S.D., de Lima, C.A., Lovato, D.V., Juliano, M.A., Torquato, R.J., Tanaka, A.S., 2008. BmSI-7, a novel subtilisin inhibitor from Boophilus microplus, with activity toward Pr1 proteases from the fungus Metarhizium anisopliae. Exp Parasitol. 118, 214-220. 
Scheer, M., Grote, A., Chang, A., Schomburg, I., Munaretto, C., Rother, M., Söhngen, C., Stelzer, M., Thiele, J., Schomburg, D., 2011. BRENDA, the enzyme information system in 2011. Nucleic Acids Res. 39(Database issue): D670-D676.

Seetharam, A., Bai, Y., Stuart, G.W., 2010. A survey of well conserved families of $\mathrm{C} 2 \mathrm{H} 2$ zinc-finger genes in Daphnia. BMC Genomics, 11, 276.

Simser, J.A., Mulenga, A., Macaluso, K.R., Azad, A.F., 2004. An immune responsive factor D-like serine proteinase homologue identified from the American dog tick, Dermacentor variabilis. Insect Mol Biol. 13, 25-35.

Sojka, D., Franta, Z., Horn, M., Hajdusek, O., Caffrey, C.R., Mares, M., Kopácek, P., 2008. Profiling of proteolytic enzymes in the gut of the tick Ixodes ricinus reveals an evolutionarily conserved network of aspartic and cysteine peptidases. Parasit. Vectors. 1, 7.

Song, B., Liu, X.S., Liu, X., 2012. Polo-like kinase 1 (Plk1): an Unexpected Player in DNA Replication. Cell Div. 7, 3.

Stenmark, H., Olkkonen, V.M., 2001. The Rab GTPase family. Genome Biol. 2, reviews 3007.13007.7 .

Tatusov, R.L., Fedorova, N.D., Jackson, J.D., Jacobs, A.R., Kiryutin, B., Koonin, E.V., Krylov, D.M., Mazumder, R., Mekhedov, S.L., Nikolskaya, A.N., Rao, B.S., Smirnov, S., Sverdlov, A.V., Vasudevan, S., Wolf, Y.I., Yin, J.J., Natale, D.A., 2003. The COG database: an updated version includes eukaryotes. BMC Bioinformatics. 4, 41.

Thompson, D.M., Khalii, S.M., Jeffers, L.A., Sonenshine, D.E., Mitchell, R.D., Osgood, C.J., Michael Roe, R., 2007. Sequence and the developmental and tissue specific regulation of the first complete vitellogenin messenger RNA from ticks responsible for heme sequestration. Insect Biochem. Mol. Biol. 37, 363-374.

Todd, S.M., Sonenshine, D.E., Hynes, W.L., 2007. Tissue and life-stage distribution of a defensin gene in the Lone Star tick, Amblyomma americanum. Med. Vet. Entomol. 21, 141-147. 
Tønnesen, M.H., Penzhorn, B.L., Bryson, N.R., Stoltsz, W.H., Masibigiri, T., 2004. Displacement of Boophilus decoloratus by Boophilus microplus in the Soutpansberg region, Limpopo Province, South Africa. Exp. Appl. Acarol. 32, 199-208.

Tufail, M., Takeda, M., 2009. Insect vitellogenin/lipophorin receptors: molecular structures, role in oogenesis, and regulatory mechanisms. J. Insect Physiol. 55, 87-103.

Turki-Judeh, W., Courey, A.J., 2012. Groucho: a corepressor with instructive roles in development. Curr. Top. Dev. Biol. 98, 65-96.

Uhlik, M.T., Abell, A.N., Cuevas, B.D., Nakamura, K., Johnson, G.L., 2004. Wiring diagrams of MAPK regulation by MEKK1, 2, and 3. Biochem. Cell Biol. 82, 658-663.

Ullmann, A.J., Lima, C.M.R., Guerrero, F.D., Piesman, J., Black, W.C.,2005. Genome size and organization in the blacklegged tick, Ixodes scapularis and the Southern cattle tick, Boophilus microplus. Insect Mol. Biol. 14, 217-222.

Vanier, M.T., Millat, G., 2004. Structure and function of the NPC2 protein. Biochim Biophys Acta. $1685,14-21$.

Vardanyan, A., Atanesyan, L., Egli, D., Raja, S.J., Steinmann-Zwicky, M., Renkawitz-Pohl, R., Georgiev, O., Schaffner, W., 2008. Dumpy-30 family members as determinants of male fertility and interaction partners of metal-responsive transcription factor 1 (MTF-1) in Drosophila. BMC Dev Biol. 8, 68.

Wang, M., Guerrero, F.D., Pertea, G., Nene, V.M., 2007. Global comparative analysis of ESTs from the southern cattle tick, Rhipicephalus (Boophilus) microplus. BMC Genomics. 8, 368.

Wang, Z., Gerstein, M., Snyder, M., (2009). RNA-Seq: a revolutionary tool for transcriptomics. Nat Rev Genet. 10, 57-63.

Watkins, N.J., Bohnsack, M.T., 2012. The box C/D and H/ACA snoRNPs: key players in the modification, processing and the dynamic folding of ribosomal RNA. Wiley Interdiscip. Rev. RNA. 3, 397-414. 
Weers, P.M., Ryan, R.O., 2006. Apolipophorin III: role model apolipoprotein. Insect Biochem. Mol. Biol. 36, 231-240.

Willadsen, P., Smith, D., Cobon, G., McKenna, R.V., 1996. Comparative vaccination of cattle against Boophilus microplus with recombinant antigen Bm86 alone or in combination with recombinant Bm91. Parasite Immunol. 18, 241-246.

Wilson, J.E., 2003. Isozymes of mammalian hexokinase: structure, subcellular localization and metabolic function. J Exp Biol. 206(Pt 12), 2049-2057.

Winchester, B.G., 2001. Lysosomal membrane proteins. Eur. J. Paediatr. Neurol. 5 (Suppl A), 11-19.

Yoshitome, S., Furuno, N., Prigent, C., Hashimoto, E., 2012. The subcellular localization of cyclin B2 is required for bipolar spindle formation during Xenopus oocyte maturation. Biochem. Biophys. Res. Commun. 422, 770-775.

Zheng, X.M., Black, D., Chambon, P., Egly, J.M., 1990. Sequencing and expression of complementary DNA for the general transcription factor BTF3. Nature. 344, 556-559.

Zhu, K., Dillwith, J.W., Bowman, A.S., Sauer, J.R., 1997. Identification of hemolytic activity in saliva of the lone star tick (Acari:Ixodidae). J. Med. Entomol. 34, 160-166. 


\section{Figures}

A.

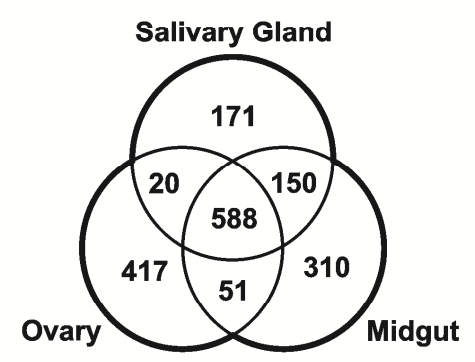

B.

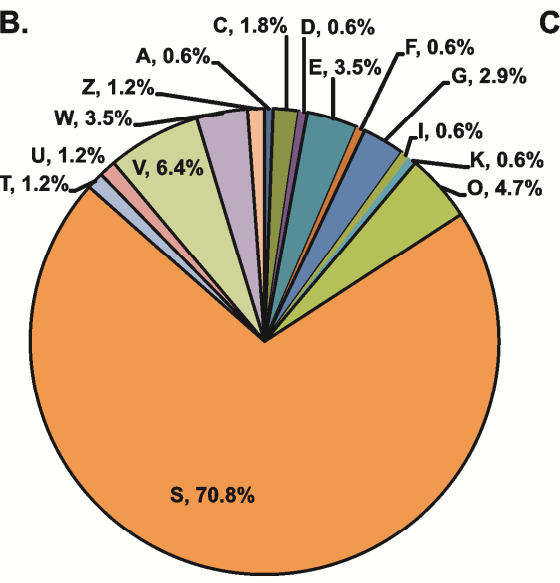

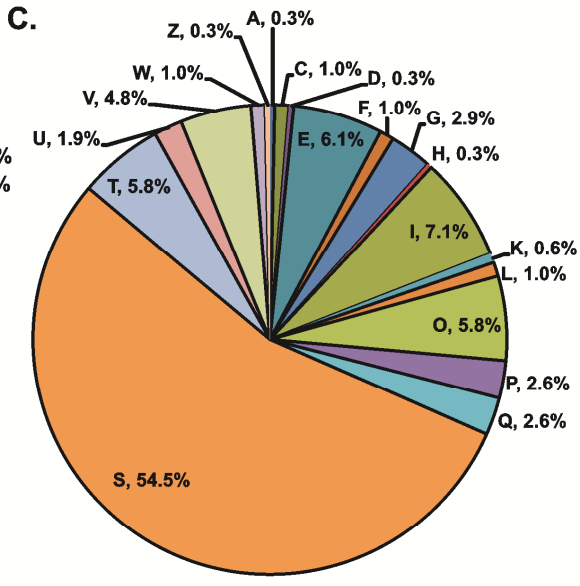
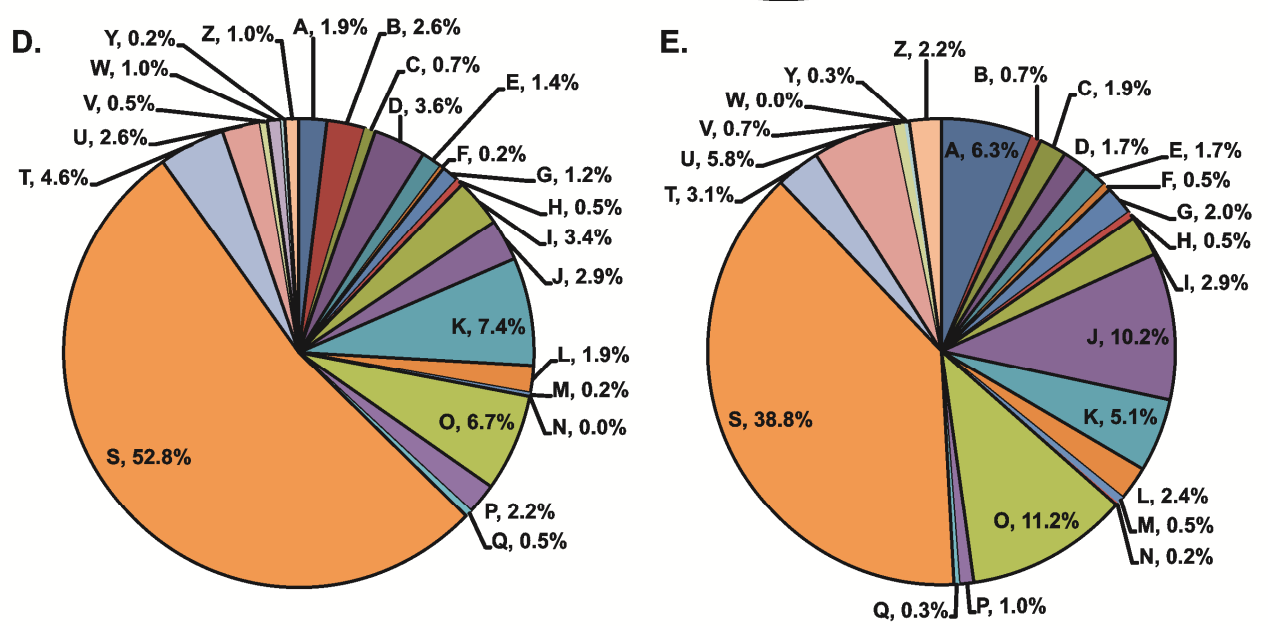

Fig. 1. Distribution and classification of genes regulated between tissues of feeding female Rhipicephalus microplus ticks. Indicated are the number of unique genes shared between midgut, salivary glands and ovaries with $\mathrm{M}$ values $>0$, an intensity threshold above 1,000 and $P$ values $\leq 0.001$. (A) Venn diagram indicating the number of genes that are unique to or shared between the different tissues. Regulated transcripts in all tissues are classified according to their eukaryotic orthologous functional groups (KOGs). The percentages of unique transcripts regulated in (B) salivary glands, (C) midgut, (D) ovaries and (E) shared between all tissues of female $R$. microplus ticks during feeding are indicated. The functional classifications that are represented include: A, RNA processing and modification; B, chromatin structure and dynamics; C, energy production and conversion; D, cell cycle control, cell division, chromosome partitioning; E, amino acid transport and metabolism; F, nucleotide transport and metabolism; G, carbohydrate transport and metabolism; H, coenzyme transport and metabolism; I, lipid transport and metabolism; J, translation, ribosomal structure and biogenesis; K, transcription; L, replication, recombination and repair; $\mathrm{M}$, cell wall/membrane/envelope biogenesis; $\mathrm{N}$, cell motility; $\mathrm{O}$, posttranslational modification, protein turnover, chaperones; $\mathrm{P}$, inorganic ion transport and metabolism; Q, secondary metabolites biosynthesis, transport and catabolism; S, function unknown (also includes transcripts with only general functional predictions); T, signal transduction mechanisms; $\mathrm{U}$, intracellular trafficking, secretion and vesicular transport; $\mathrm{V}$, defense mechanisms; W, extracellular structures; Y, nuclear structure; Z, cytoskeleton. 


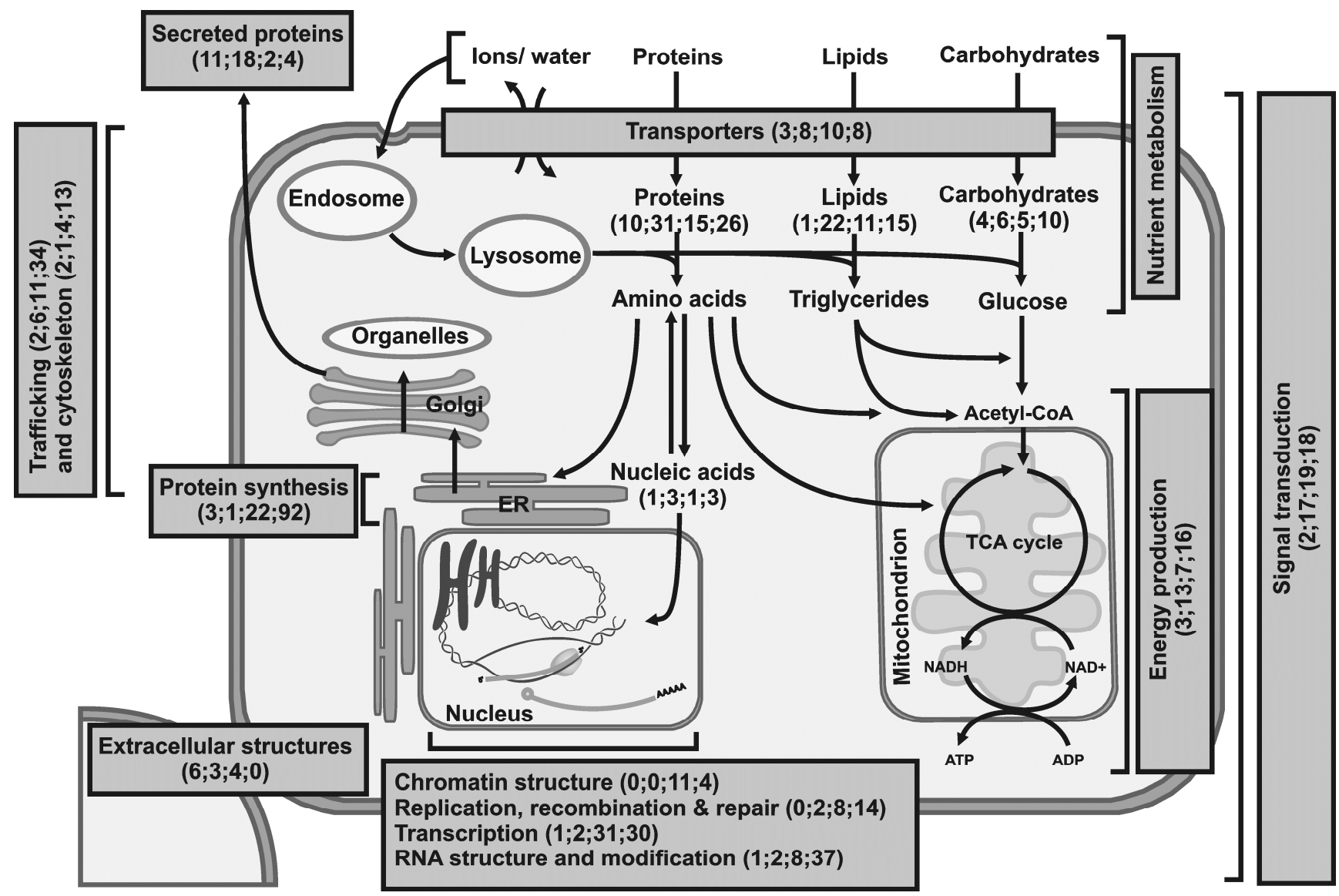

Fig. 2. Overview of regulated transcripts in the tissues of feeding female Rhipicephalus microplus ticks. A simplified cell and biological pathways with key processes in blocks are indicated, as well as the relative number of transcripts (in brackets) involved in each process representing salivary glands, midguts, ovaries and shared between all tissues, respectively. The key functional processes represented are: secreted proteins (including anti-coagulants and antimicrobials) that could also include enzymes involved in nutrient acquisition (proteases and lipases); nutrient metabolism that includes both intracellular and extracellular enzymes and transport proteins; enzymes and proteins involved in energy production; enzymes and proteins involved in chromosome structure, replication, transcription, as well as RNA processing and modification; proteins and enzymes involved in protein synthesis, proteins involved in intracellular trafficking and the cytoskeleton, extracellular structures involved in cell-cell contact; receptors, enzymes and accessory proteins involved in signal transduction events throughout the cell. ER, endoplasmic reticulum; TCA, tricarboxylic acid. 
Table 1. Summary of unique transcripts expressed in tissues of feeding Rhipicephalus microplus female ticks $(P \leq 0.001)$. Numbers of transcripts were determined using an intensity threshold of a 1,000 and an average absolute two-fold change relative to other tissues.

\begin{tabular}{|c|c|c|c|c|c|c|}
\hline & Regulated & Fold change $^{b}$ & Salivary gland & Midgut & Ovary & All tissues \\
\hline \multicolumn{7}{|l|}{ Regulation of significant } \\
\hline & & $>2$ & 62 & 210 & 102 & \\
\hline & & $>1$ & 171 & 310 & 417 & \\
\hline & No change & $>5,000^{\star}$ & - & - & - & 74 \\
\hline & & $>2,000^{*}$ & & & & 135 \\
\hline & & $>1,000^{*}$ & & & & 588 \\
\hline $\begin{array}{l}\text { Total regulated genes } \\
\text { above intensity threshold }{ }^{c}\end{array}$ & 5,175 & & 520 & 552 & 994 & 588 \\
\hline $\begin{array}{l}\text { Total regulated genes with } \\
P \text { value } \leq 0.001^{d}\end{array}$ & 1,707 & & 171 & 310 & 417 & $588^{f}$ \\
\hline$\%$ Regulated genes ${ }^{e}$ & 12.7 & & 1.3 & 2.3 & 3.1 & 4.4 \\
\hline
\end{tabular}

a. Data corresponds to fold change values using an empirical Bayes method to identify differentially expressed transcripts with a $P$ value $\leq$ 0.001 adjusted for multiple comparison false discovery rates.

${ }^{b}$ Fold change corresponding to the $\log _{2}$ expression ratio of genes with at least a greater than two-fold absolute expression for any given tissue comparison.

c. Total number of genes regulated above an intensity threshold of 1,000 and an $M$ value $($ Cy5/Cy 3$)>0$.

d. Total number of genes regulated with a $P$ value $\leq 0.001$ adjusted for multiple comparison false discovery rates.

e.Percentage of genes regulated from 13,456 total transcripts used on the microarray.

${ }^{\dagger}$ Number of non-differentially expressed genes for all tissue comparisons based on $\mathrm{M}$ value (Cy5/Cy3) $>0$ and a minimum threshold intensity of 1,000 . 
Table 2. Summary of unique and shared transcripts expressed in feeding adult Rhipicephalus microplus females.

\begin{tabular}{|c|c|c|c|c|c|c|c|c|c|c|c|c|c|c|c|c|}
\hline \multirow{2}{*}{$\begin{array}{l}\text { Transcript category } \\
\text { (KOG classification) }^{\mathrm{a}}\end{array}$} & \multicolumn{4}{|c|}{ Salivary gland ${ }^{b}$} & \multicolumn{4}{|c|}{ Midgut $^{\mathrm{b}}$} & \multicolumn{4}{|c|}{ Ovary $^{b}$} & \multicolumn{4}{|c|}{ Shared transcripts ${ }^{\circ}$} \\
\hline & Quantity $^{d}$ & Enzyme $^{e}$ & Transport $^{\dagger}$ & $\begin{array}{l}\text { Average } \\
{\text { log } \mathrm{FC}^{g}}^{2}\end{array}$ & Quantity $^{d}$ & Enzyme $^{e}$ & Transport $^{t}$ & $\begin{array}{l}\text { Average } \\
\text { logFC }^{9}\end{array}$ & Quantity $^{d}$ & Enzyme $^{e}$ & Transport $^{t}$ & $\begin{array}{l}\text { Average } \\
\text { logFC }^{9}\end{array}$ & Quantity $^{d}$ & Enzyme $^{e}$ & Transport $^{\dagger}$ & $\begin{array}{l}\text { Intensity } \\
\text { threshold } \\
>2000^{\mathrm{h}} \\
\end{array}$ \\
\hline A. RNA processing and modification & 1 & & & 2.81 & 2 & 1 & & $\begin{array}{l}4.36- \\
3.47\end{array}$ & 8 & 6 & & $\begin{array}{r}3.32- \\
1.48\end{array}$ & 37 & 13 & & 8 \\
\hline B. Chromatin structure and dynamics & & & & & & & & & 11 & & & $\begin{array}{r}4.94- \\
1.55\end{array}$ & 4 & & & \\
\hline C. Energy production and conversion & 3 & 3 & & $1.44-1.2$ & 3 & 3 & & $\begin{array}{l}3.39- \\
2.64\end{array}$ & 3 & & 3 & $1.95-1.5$ & 11 & 4 & 7 & 7 \\
\hline $\begin{array}{l}\text { D. Cell cycle control, cell division, } \\
\text { chromosome partitioning }\end{array}$ & 1 & & & 1.89 & 1 & 1 & & 4.1 & 15 & 7 & & $2.84-1.1$ & 10 & 3 & & \\
\hline E. Amino acid transport and metabolism & 6 & 5 & 1 & $\begin{array}{r}3.26- \\
1.27\end{array}$ & 19 & 19 & & $\begin{array}{l}5.48- \\
1.28\end{array}$ & 6 & 5 & 1 & $\begin{array}{r}4.80- \\
2.27\end{array}$ & 10 & 9 & & 2 \\
\hline F. Nucleotide transport and metabolism & 1 & & 1 & 1.86 & 3 & 3 & & $\begin{array}{r}3.46- \\
1.56\end{array}$ & 1 & 1 & & 1.69 & 3 & 3 & & 1 \\
\hline G. Carbohydrate transport and metabolism & 5 & 4 & 1 & $3.78-1.7$ & 8 & 6 & 2 & $\begin{array}{r}4.72- \\
1.71\end{array}$ & 5 & 5 & & $2.62-1.3$ & 12 & 9 & 2 & 4 \\
\hline H. Coenzyme transport and metabolism & & & & & 2 & 2 & & $\begin{array}{l}3.35- \\
2.89\end{array}$ & 2 & 2 & & $\begin{array}{r}1.30- \\
1.19\end{array}$ & 3 & 3 & & \\
\hline I. Lipid transport and metabolism & 1 & 1 & & 1.82 & 22 & 13 & & $\begin{array}{r}5.59- \\
1.27\end{array}$ & 14 & 11 & 3 & $\begin{array}{r}4.24- \\
1.57\end{array}$ & 17 & 11 & 2 & 3 \\
\hline $\begin{array}{l}\text { J. Translation, ribosomal structure and } \\
\text { biogenesis }\end{array}$ & & & & & & & & & 12 & 1 & & $\begin{array}{r}3.42- \\
1.14\end{array}$ & 60 & 9 & & 16 \\
\hline K. Transcription & 1 & & & 1.66 & 2 & & & $\begin{array}{r}4.03- \\
1.27\end{array}$ & 31 & 6 & & $\begin{array}{r}1.14 \\
3.18- \\
1.07\end{array}$ & 30 & 6 & & 6 \\
\hline L. Replication, recombination and repair & & & & & 2 & 2 & & $\begin{array}{l}5.18- \\
4.47\end{array}$ & 8 & 1 & & $2.94-1.1$ & 14 & 9 & & \\
\hline $\begin{array}{l}\text { M. Cell wall/membrane/envelope } \\
\text { biogenesis }\end{array}$ & & & & & & & & & 1 & & & 3.11 & 3 & & & \\
\hline N. Cell motility & & & & & & & & & & & & & 1 & & & \\
\hline $\begin{array}{l}\text { O. Posttranslational modification, protein } \\
\text { turnover, chaperones }\end{array}$ & 8 & 4 & & $\begin{array}{r}2.89- \\
1.55\end{array}$ & 16 & 15 & & $\begin{array}{r}5.55- \\
1.44\end{array}$ & 28 & 17 & & $\begin{array}{r}4.01- \\
1.04\end{array}$ & 66 & 31 & 1 & 19 \\
\hline P. Inorganic ion transport and metabolism & & & & & 8 & 2 & 6 & $5.56-1.9$ & 9 & & 6 & $\begin{array}{r}3.09- \\
1.37\end{array}$ & 6 & & 4 & 1 \\
\hline $\begin{array}{l}\text { Q. Secondary metabolites biosynthesis, } \\
\text { transport and catabolism }\end{array}$ & & & & & 8 & 6 & 2 & $\begin{array}{r}4.01- \\
1.76\end{array}$ & 2 & 1 & 1 & $\begin{array}{r}1.87- \\
1.56\end{array}$ & 2 & 1 & & \\
\hline s. Function unknown & 121 & & & & 169 & & & & 220 & & & & 228 & & & \\
\hline T. Signal transduction mechanisms & 2 & 1 & & $\begin{array}{r}2.66- \\
1.72\end{array}$ & 17 & 4 & & $\begin{array}{r}5.17- \\
1.38\end{array}$ & 19 & 6 & & $3.8-1.1$ & 18 & 6 & & 3 \\
\hline $\begin{array}{l}\text { U. Intracellular trafficking, secretion, and } \\
\text { vesicular transport }\end{array}$ & 2 & & & $\begin{array}{l}2.54- \\
1.85\end{array}$ & 6 & 3 & 1 & $\begin{array}{l}3.68- \\
1.31\end{array}$ & 11 & 1 & & $\begin{array}{r}3.53- \\
1.17\end{array}$ & 34 & 4 & 6 & 11 \\
\hline V. Defense mechanisms & 11 & & & $\begin{array}{r}3.49- \\
1.26\end{array}$ & 18 & & & $\begin{array}{l}5.15- \\
1.55\end{array}$ & 2 & 1 & & $\begin{array}{r}1.56- \\
1.18\end{array}$ & 4 & 2 & & 1 \\
\hline W. Extracellular structures & 6 & & & $\begin{array}{l}5.99- \\
1.44\end{array}$ & 3 & & & $\begin{array}{l}4.02- \\
2.51\end{array}$ & 4 & & & $\begin{array}{l}3.10 \\
2.67-\end{array}$ & 0 & & & \\
\hline Y. Nuclear structure & & & & & & & & & 1 & & 1 & 1.22 & 2 & & 2 & \\
\hline Z. Cytoskeleton & 2 & & & $\begin{array}{r}1.12- \\
1.09 \\
\end{array}$ & 1 & & & 3.01 & 4 & & & $\begin{array}{r}2.51- \\
1.01\end{array}$ & 13 & & & 7 \\
\hline Total & 171 & 18 & 3 & & 310 & 80 & 11 & & 417 & 71 & 15 & & 588 & 123 & 24 & 90 \\
\hline
\end{tabular}

b. Unique transcripts expressed in tissues of feeding $R$. microp/us female ticks. Transcripts determined using an M value $>0$, a minimum threshold of 1,000 and an absolute two-fold change regulation of genes relative to other tissues, $P$ value $\leq 0.001$.

c. Shared transcripts expressed in all tissues of feeding $R$. microplus female ticks. Transcripts determined using an $\mathrm{M}$ value $>0$ and a minimum intensity threshold of 1,000.

d. Total number of transcripts per category. 
e. Total number of transcripts identified with putative enzymatic function.

total number of transcripts identified with putative transporter function.

${ }^{9}$ Highest and lowest average $\log _{2}$ expression for transcripts per category. Average $\log _{2}$ expression obtained for up-regulated genes across all tissue comparisons, using the arithmetic mean to obtain an overall change in expression for each gene. Log ${ }_{2}$ expression ratios (LogFC) calculated for group pair-wise comparisons, to identify significantly differentially expressed transcripts with $P$ values adjusted for multiple comparisons false discovery rates.

h. Total number of transcripts with $\mathrm{M}$ values $>0$ and Cy5 intensities $>2,000$ in all tissues tested that are considered to be shared. 
Supplementary Table S1. Primer sequences (5' to $3^{\prime}$ ) used in quantitative PCR (qPCR) analysis for validation of microarray results including reference gene primer sets used for normalization.

\begin{tabular}{lll}
\hline Primer set & Forward & Reverse \\
\hline Contig1 & TGGCGTTCATCCTTCAGTTC & GCGTTCTTCTCTCCGTAAATGTC \\
Contig5396 & AACTTCCCGAAGATTCTGTGTG & CGTATCCTTTCTCCTTGTGTTTG \\
Contig5672 & CTTCCGTGACGATGATACACC & CTTCACATTTATCCCATCCATCC \\
Contig8723 & ATGATCGGCAAGAAGCGTCT & GGAAACCCTTTGTGACACCCTT \\
Elongation & CGTCTACAAGATTGGTGGCATT & CTCAGTGGTCAGGTTGGCAG \\
factor 1 alpha & & \\
(Contig8418) & & \\
\hline
\end{tabular}


Supplementary Table S3. Unique transcripts expressed in salivary gland tissues of feeding Rhipicephalus microplus female ticks $(P \leq 0.001)$ identified from microarray analysis. Transcripts were chosen using an intensity threshold of 1,000 and an absolute two-fold change regulation of genes relative to other tissues tested.

\begin{tabular}{|c|c|c|c|c|c|c|}
\hline $\begin{array}{l}\text { Transcript category } \\
\text { (KOG classification) }^{\text {a }}\end{array}$ & Contig $^{b}$ & Description $^{\circ}$ & Species $^{\mathrm{d}}$ & $\begin{array}{l}\mathrm{MG} / \mathrm{SG}^{\mathrm{e}} \\
\log \mathrm{FC}^{g}\end{array}$ & $\begin{array}{l}\mathrm{O} / \mathrm{SG}^{f} \\
\log ^{\prime} \mathrm{F}^{g}\end{array}$ & Average $\log \mathrm{FC}^{\mathrm{h}}$ \\
\hline \multirow{6}{*}{$\begin{array}{l}\text { Amino acid transport and } \\
\text { metabolism }\end{array}$} & Contig1 & Putative peptidyl-dipeptidase A, angiotensin-converting enzyme (ACE), Peptidase M2 family & Rhipicephalus microp/us & -3.06 & -3.46 & 3.26 \\
\hline & Contig486 & Putative Serine proteinase stubble $(\mathrm{Sb})$, Peptidase $\mathrm{S} 1$ family & Dermacentor variabilis & -2.91 & -1.26 & 2.09 \\
\hline & Contig1049 & Putative aspartate aminotransferase (GOT2), Class-I pyridoxal-phosphate-dependent aminotransferase family & Ixodes scapularis & -1.99 & -2.16 & 2.07 \\
\hline & Contig6588 & Putative amino acid transporter (AVT1), Amino acid/polyamine transporter 2 family & Ixodes scapularis & -1.99 & -1.95 & 1.97 \\
\hline & Contig7971 & Putative beta-ureidopropionase (BUP1), CN hydrolase family, BUP subfamily & Ixodes scapularis & -1.64 & -1.18 & 1.41 \\
\hline & CV446779 & Putative Kynureninase (Kynu), Kynureninase family & Ixodes scapularis & -1.54 & -1.01 & 1.27 \\
\hline \multirow{5}{*}{$\begin{array}{l}\text { Carbohydrate transport } \\
\text { and metabolism }\end{array}$} & CV443183 & Putative aquaporin, MIP/aquaporin family & Ixodes scapularis & -2.32 & -5.25 & 3.78 \\
\hline & Contig3556 & Putative chitinase 5 (Cht5), Glycosyl hydrolase 19 family, Chitinase class IV subfamily & Rhipicephalus sanguineus & -2.98 & -2.93 & 2.95 \\
\hline & Contig1658 & Putative glucose-6-phosphate isomerise (Gpi), GPI family & Melitaea cinxia & -2.51 & -1.26 & 1.88 \\
\hline & Contig1253 & Putative phosphoglycerate mutase (GPMI), Phosphoglycerate mutase family, BPG-dependent PGAM subfamily & Ixodes scapularis & -1.24 & -2.25 & 1.75 \\
\hline & Contig2118 & Putative phosphoglycerate kinase (PGK), Phosphoglycerate kinase family & Ixodes scapularis & -1.31 & -2.09 & 1.70 \\
\hline Cell cycle control, cell & & & & & & \\
\hline $\begin{array}{l}\text { division, chromosome } \\
\text { partitioning }\end{array}$ & Contig2775 & Putative BCL2/adenovirus E1B $19 \mathrm{kDa}$ protein-interacting protein 3 (BNIP3), NIP3 family & Ixodes scapularis & -1.78 & -2.00 & 1.89 \\
\hline \multirow[t]{2}{*}{ Cytoskeleton } & CV441126 & Putative microtubule-associated proteins 1A/1B light chain 3A (MAP1LC3A), MAP1 LC3 family & Monodelphis domestica & -1.03 & -1.20 & 1.12 \\
\hline & CV436085 & Putative thyroid receptor-interacting protein 11 -like (TRIP11) & $\begin{array}{l}\text { Strongylocentrotus } \\
\text { purpuratus }\end{array}$ & -1.04 & -1.14 & 1.09 \\
\hline \multirow[t]{2}{*}{ Defense mechanisms } & Contig1520 & Putative serpin, Serine protease inhibitor, Serpin family & $\begin{array}{l}\text { Rhipicephalus } \\
\text { appendiculatus }\end{array}$ & -3.76 & -3.23 & 3.49 \\
\hline & Contig6586 & Putative serpin, Serine protease inhibitor, Serpin family & Ixodes scapularis & -3.02 & -2.77 & 2.89 \\
\hline
\end{tabular}




\begin{tabular}{|c|c|c|c|c|c|c|}
\hline \multirow[t]{2}{*}{$\begin{array}{l}\text { Transcript category } \\
\text { (KOG classification) }^{\text {a }}\end{array}$} & Contig $^{b}$ & Description $^{c}$ & Species $^{d}$ & $\begin{array}{l}\mathrm{MG} / \mathrm{SG}^{\mathrm{e}} \\
\log \mathrm{FC}^{g}\end{array}$ & $\begin{array}{l}\mathrm{O} / \mathrm{SG}^{f} \\
\log \mathrm{FC}^{g}\end{array}$ & Average $\log \mathrm{FC}^{\mathrm{h}}$ \\
\hline & Contig5482 & Putative antimicrobial peptide, Defensin & Rhipicephalus microplus & -2.96 & -2.64 & 2.80 \\
\hline \multirow[t]{8}{*}{ Defense mechanisms } & Contig2493 & $\begin{array}{l}\text { Putative histamine binding protein (HBP), Lipocalin, Calycin superfamily } \\
\end{array}$ & Rhipicephalus sanguineus & -2.85 & -2.65 & 2.75 \\
\hline & CK178656 & Putative serpin, Serine protease inhibitor, Serpin family & Ixodes scapularis & -2.90 & -2.58 & 2.74 \\
\hline & CK177092 & Putative antimicrobial peptide, Microplusin-like protein & Amblyomma hebraeum & -2.23 & -2.64 & 2.43 \\
\hline & Contig2529 & Putative histamine binding protein (HBP), Lipocalin, Calycin superfamily & Rhipicephalus sanguineus & -2.26 & -2.09 & 2.18 \\
\hline & Contig5501 & Putative astakine, Prokineticin family, innate immunity & Acyrthosiphon pisum & -2.56 & -1.66 & 2.11 \\
\hline & Contig300 & Putative thyropin, Thyroglobulin type-1 repeat containing protein & Rhipicephalus sanguineus & -2.74 & -1.46 & 2.10 \\
\hline & Contig688 & Putative serpin, Serine protease inhibitor, Serpin family & Ixodes ricinus & -2.16 & -1.20 & 1.68 \\
\hline & Contig8207 & Putative trypsin inhibitor like cysteine rich domain-containing protein (TLL), TLL superfamily & Ixodes scapularis & -1.15 & -1.38 & 1.26 \\
\hline \multirow{3}{*}{$\begin{array}{l}\text { Energy production and } \\
\text { conversion }\end{array}$} & Contig240A & Putative NADH dehydrogenase (ubiquinone) 1 alpha subcomplex subunit 10 (ND42) & Ixodes scapularis & -1.11 & -1.78 & 1.44 \\
\hline & Contig1269 & Putative malate dehydrogenase (MDH2), LDH/MDH superfamily, MDH type 1 family & Ixodes scapularis & -1.34 & -1.33 & 1.34 \\
\hline & Contig211 & Putative succinate dehydrogenase (ubiquinone) (SDHB), Succinate dehydrogenase/fumarate reductase iron-sulfur protein family & Ixodes scapularis & -1.06 & -1.34 & 1.20 \\
\hline \multirow[t]{5}{*}{ Extracellular structures } & CV452616 & Putative mucin/peritrophin-like protein & Drosophila melanogaster & -5.30 & -6.67 & 5.99 \\
\hline & Contig2328 & Putative cement protein, Glycine-rich protein & Ixodes scapularis & -2.83 & -4.04 & 3.43 \\
\hline & CV437645 & Putative cuticle collagen 155 (col-155), Cuticular collagen family, Glycine-rich protein & $\begin{array}{l}\text { Coccidioides posadasii } \\
\text { C735 delta SOWgp }\end{array}$ & -1.69 & -2.79 & 2.24 \\
\hline & Contig4354 & Putative collagen alpha-5(IV) chain (COL4A5), Type IV collagen family, Glycine-rich protein & Ixodes scapularis & -1.17 & -1.74 & 1.45 \\
\hline & Contig642 & Putative cement protein, Glycine-rich protein & Ixodes scapularis & -1.65 & -1.24 & 1.44 \\
\hline \multicolumn{7}{|l|}{ Intracellular trafficking, } \\
\hline \multirow{2}{*}{$\begin{array}{l}\text { secretion, and vesicular } \\
\text { transport }\end{array}$} & Contig470 & Putative Rab5 GDP/GTP exchange factor (RABGEF1) & Ixodes scapularis & -3.07 & -2.01 & 2.54 \\
\hline & CK187367 & Putative trafficking protein particle complex subunit 9 (TRAPPC9), NIBP family & Ixodes scapularis & -1.77 & -1.93 & 1.85 \\
\hline $\begin{array}{l}\text { Lipid transport and } \\
\text { metabolism }\end{array}$ & CV454720 & Putative phospholipase A2, Phospholipase A2 family & Ixodes scapularis & -1.54 & -2.10 & 1.82 \\
\hline Nucleotide transport and & CV438968 & Putative solute carrier family 23 member 2 (SIc23a2), Xanthine/uracil permease family, Nucleobase:cation symporter-2 (NCS2) & Branchiostoma floridae & -1.38 & -2.34 & 1.86 \\
\hline
\end{tabular}




\begin{tabular}{|c|c|c|c|c|c|c|}
\hline $\begin{array}{l}\text { Transcript category } \\
\text { (KOG classification) }^{\mathrm{a}}\end{array}$ & Contig $^{b}$ & Description $^{c}$ & Species $^{\mathrm{d}}$ & $\begin{array}{l}\mathrm{MG} / \mathrm{SG}^{\mathrm{e}} \\
\log \mathrm{FC}^{g}\end{array}$ & $\begin{array}{l}\mathrm{O} / \mathrm{SG}^{f} \\
\log ^{\mathrm{FC}} \mathrm{C}^{g}\end{array}$ & Average $\log \mathrm{FC}^{\mathrm{h}}$ \\
\hline metabolism & & subfamily & & & & \\
\hline \multicolumn{7}{|l|}{ Posttranslational } \\
\hline \multirow{10}{*}{$\begin{array}{l}\text { modification, protein } \\
\text { turnover, chaperones }\end{array}$} & Contig5601 & Putative heat shock proteins, Small heat shock protein (HSP20) family & Ixodes scapularis & -3.02 & -2.77 & 2.89 \\
\hline & CV454094 & Putative heat shock proteins, Small heat shock protein (HSP20) family & Ixodes scapularis & -2.39 & -3.32 & 2.86 \\
\hline & Contig6614 & Putative cathepsin B, Peptidase C1 family, Longipain-like protein & Haemaphysalis Iongicornis & -2.48 & -2.98 & 2.73 \\
\hline & & & Rhipicephalus & & & \\
\hline & Contig1050 & Putative cathepsin L, Peptidase C1 family & haemaphysaloides & -2.84 & -2.18 & 2.51 \\
\hline & & & haemaphysaloides & & & \\
\hline & Contig2131 & Putative alpha-2-macroglobulin-like protein (A2ML1), Protease inhibitor 139 (alpha-2-macroglobulin) family & Amblyomma americanum & -3.22 & -1.64 & 2.43 \\
\hline & Contig1745 & Putative alpha-2-macroglobulin-like protein (A2ML1), Protease inhibitor I39 (alpha-2-macroglobulin) family & Ixodes ricinus & -2.93 & -1.68 & 2.31 \\
\hline & TC23043 & $\begin{array}{l}\text { Putative protein-L-isoaspartate(D-aspartate) O-methyltransferase (Pcmt1), Methyltransferase superfamily, L-isoasparty/D- } \\
\text { aspartyl protein methyltransferase family }\end{array}$ & Ixodes scapularis & -1.64 & -2.13 & 1.89 \\
\hline & Contig6519 & Putative peptidylprolyl isomerase (FKBP2), FKBP-type PPlase family, FKBP2 subfamily & Ixodes scapularis & -1.34 & -1.77 & 1.55 \\
\hline $\begin{array}{l}\text { RNA processing and } \\
\text { modification }\end{array}$ & CK177403 & Putative RNA-binding protein Musashi (Rbp6), Musashi family & Tribolium castaneum & -3.07 & -2.55 & 2.81 \\
\hline \multirow[t]{2}{*}{$\begin{array}{l}\text { Signal transduction } \\
\text { mechanisms }\end{array}$} & Contig4877 & $\begin{array}{l}\text { Putative mitogen-activated protein kinase kinase kinase } 1 \text { (MAP3K1), Protein kinase superfamily, STE Ser/Thr protein kinase } \\
\text { family, MAP kinase kinase kinase subfamily }\end{array}$ & Ixodes scapularis & -2.35 & -2.98 & 2.66 \\
\hline & Contig5314 & Putative tetraspanin 5 (TSPAN5), Tetraspanin (TM4SF) family & Ixodes scapularis & -1.91 & -1.52 & 1.72 \\
\hline Transcription & Contig663 & Putative cyclin L2 (CCNL2), Cyclin family, Cyclin L subfamily & Ixodes scapularis & -1.74 & -1.59 & 1.66 \\
\hline
\end{tabular}

${ }^{a}$ Classification of transcripts according to eukaryotic ortologous group terms for gene ontology (Tatusov et al., 2003).

${ }^{\mathrm{b}}$ Assigned contiguous sequence identification for transcripts following assembly of all available expressed sequence tags and the R. microp/us Gene Index version 2.1.

${ }^{c}$ The functional annotation of genes based on comparison among BLAST outputs from seven databases outlined in Section 2.4. All transcript descriptions are based on consensus with database entries from Uniprot (http://www.uniprot.org/uniprot/) and BRENDA (http://www.brenda-enzymes.org/), in the case of enzymes.

${ }^{\mathrm{d} S}$ Species indicated that showed the highest sequence similarity to R. microplus sequences following non-redundant database (NR) BLAST analysis, independent of final assignment.

${ }^{\mathrm{e}} \mathrm{Log} \mathrm{g}_{2}$ expression ratios (LogFC) calculated for group pair-wise comparison, to identify significant differentially expressed transcripts with $P$-values adjusted for multiple comparisons false discovery rates.

' $\log _{2}$ expression for group pair-wise comparison between midgut (MG) and salivary glands (SG). Values of MG/SG $>1$ correspond to genes that are more expressed in midgut, whereas MG/SG $<1$ correspond to genes that are more expressed in salivary glands.

${ }^{9} \mathrm{Log}_{2}$ expression for group pair-wise comparison between ovaries $(\mathrm{O})$ and salivary glands $(\mathrm{SG})$. Values of $\mathrm{O} / \mathrm{SG}>1$ correspond to genes that are more expressed in midgut, whereas $\mathrm{O} / \mathrm{SG}<1$ correspond to genes that are more expressed in salivary glands. 
Supplementary Table S4. Unique transcripts expressed in midgut tissues of feeding Rhipicephalus microplus female ticks $(P \leq 0.001)$ identified from microarray analysis. Transcripts were chosen using an intensity threshold of 1,000 and an absolute two-fold change regulation of genes relative to other tissues tested.

\begin{tabular}{|c|c|c|c|c|c|c|}
\hline $\begin{array}{l}\text { Transcript category } \\
\text { (KOG classification) }^{\text {a }}\end{array}$ & Contig $^{b}$ & Description $^{c}$ & Species $^{d}$ & \begin{tabular}{|l}
$\mathrm{MG} / \mathrm{O}^{f}$ \\
$\log \mathrm{FC}^{\mathrm{e}}$
\end{tabular} & $\begin{array}{l}\mathrm{MG} / \mathrm{SG}^{g} \\
\log \mathrm{FC}^{\mathrm{e}}\end{array}$ & $\begin{array}{l}\text { Average } \\
\text { logFC }\end{array}$ \\
\hline \multirow[t]{18}{*}{$\begin{array}{l}\text { Amino acid transport and } \\
\text { metabolism }\end{array}$} & Contig6406 & Putative serine protease elastase 2 like (ela2l), Peptidase $\mathrm{S} 1$ family & $\begin{array}{l}\text { Rhipicephalus } \\
\text { appendiculatus }\end{array}$ & 6.76 & 4.21 & 5.48 \\
\hline & Contig598 & Putative serine protease chymotrypsinogen B (CTRB1), Peptidase $S 1$ family, secreted peptidase & Haemaphysalis longicornis & 6.74 & 4.19 & 5.46 \\
\hline & Contig3850 & Putative serine protease chymotrypsinogen B (CTRB1), Peptidase S1 family, secreted peptidase & Ixodes scapularis & 5.84 & 4.14 & 4.99 \\
\hline & Contig1748 & Putative L-Asparaginase, Asparaginase 1 family & Drosophila mojavensis & 5.28 & 4.25 & 4.76 \\
\hline & Contig8186 & Putative betaine-homocysteine S-methyltransferase (BHMT2) & Branchiostoma floridae & 5.44 & 3.80 & 4.62 \\
\hline & Contig5340 & Putative serine protease atrial natriuretic peptide-converting enzyme (corin), Peptidase $S 1$ family & $\begin{array}{l}\text { Rhipicephalus } \\
\text { appendiculatus }\end{array}$ & 5.24 & 3.49 & 4.37 \\
\hline & Contig1821 & Putative serine protease chymotrypsinogen $B$ (CTRB1), Peptidase $S 1$ family, secreted peptidase & Ornithodoros moubata & 4.28 & 4.05 & 4.17 \\
\hline & Contig4941 & Putative carboxypeptidase A2 (CPA2), Peptidase M14 family & Ixodes scapularis & 5.10 & 3.04 & 4.07 \\
\hline & Contig5462 & Putative serine carboxypeptidase (CPVL), Peptidase S10 family & Ixodes scapularis & 4.63 & 3.47 & 4.05 \\
\hline & Contig2855 & $\begin{array}{l}\text { Putative glycine N-methyltransferase (GNMT), Class I-like SAM-binding methyltransferase superfamily, Glycine N- } \\
\text { methyltransferase family }\end{array}$ & Ixodes scapularis & 3.85 & 3.22 & 3.53 \\
\hline & Contig5171 & Putative aminopeptidase, Peptidase M17 family & Ixodes scapularis & 4.72 & 2.12 & 3.42 \\
\hline & CV440582 & Putative pantetheine hydrolase (vanin), CN hydrolase family, BTD/VNN subfamily & Ixodes scapularis & 3.08 & 3.16 & 3.12 \\
\hline & Contig8859 & Putative arginase (ARG1), Arginase family & Ixodes scapularis & 3.72 & 2.39 & 3.05 \\
\hline & Contig3884 & Putative acireductone dioxygenase (iron(II)-requiring) (ADI1), 1,2-dihydroxy-3-keto-5-methylthiopentene dioxygenase. & Selaginella moellendorffii & 3.03 & 2.15 & 2.59 \\
\hline & Contig506 & Putative cytosol non-specific dipeptidase (CNDP), Peptidase M20A family & Ixodes scapularis & 2.64 & 2.25 & 2.45 \\
\hline & Contig6808 & Putative ornithine decarboxylase (ODC1) & Ixodes scapularis & 2.19 & 1.81 & 2.00 \\
\hline & CK175263 & Putative glycine dehydrogenase (decarboxylating) (GLDC) & Ixodes scapularis & 1.89 & 2.05 & 1.97 \\
\hline & Contig172 & Putative aminomethyltransferase (AMT) & Ixodes scapularis & 1.81 & 1.59 & 1.70 \\
\hline
\end{tabular}




\begin{tabular}{|c|c|c|c|c|c|c|}
\hline $\begin{array}{l}\text { Transcript category } \\
\text { (KOG classification) }^{a}\end{array}$ & Contig $^{b}$ & Description $^{\mathrm{C}}$ & Species $^{d}$ & \begin{tabular}{|l|}
$\mathrm{MG} / \mathrm{O}^{f}$ \\
$\log \mathrm{FC}$
\end{tabular} & $\begin{array}{l}\mathrm{MG} / \mathrm{SG}^{9} \\
\log \mathrm{FC}^{\mathrm{e}}\end{array}$ & $\begin{array}{l}\text { Average } \\
\text { logFC }^{h}\end{array}$ \\
\hline & CK175193 & Putative glycine hydroxymethyltransferase (shmt1) & Ixodes scapularis & 1.02 & 1.54 & 1.28 \\
\hline \multirow{8}{*}{$\begin{array}{l}\text { Carbohydrate transport } \\
\text { and metabolism } \\
\text { Carbohydrate transport } \\
\text { and metabolism }\end{array}$} & Contig7972 & Putative glucosylceramidase (Gba) & Ixodes scapularis & 5.16 & 4.27 & 4.72 \\
\hline & Contig6465 & Putative sialin (Sodium/sialic acid cotransporter) (SLC17A5), Solute carrier family 17 member & Ixodes scapularis & 4.78 & 3.68 & 4.23 \\
\hline & Contig8580 & Putative Alpha-L-fucosidase (FUCA2) & Ciona intestinalis & 4.59 & 3.20 & 3.90 \\
\hline & Contig4273 & Putative Alpha-L-fucosidase (FUCA2) & Ixodes scapularis & 3.66 & 2.66 & 3.16 \\
\hline & CV455491 & Putative monocarboxylate transporter 1 (SLC16A1) & Ixodes scapularis & 2.95 & 2.87 & 2.91 \\
\hline & Contig245B & Putative hexokinase & Ixodes scapularis & 2.80 & 2.53 & 2.66 \\
\hline & CV448648 & Putative glycoprotein-N-acetylgalactosamine 3-beta-galactosyltransferase 1 (C1GLT) & Nasonia vitripennis & 3.17 & 2.03 & 2.60 \\
\hline & Contig299B & Putative adenosine kinase (ADK) & Ixodes scapularis & 1.82 & 1.59 & 1.71 \\
\hline \multirow{3}{*}{$\begin{array}{l}\text { Cell cycle control, cell } \\
\text { division, chromosome } \\
\text { partitioning } \\
\text { Coenzyme transport and } \\
\text { metabolism }\end{array}$} & Contig4156 & Putative caspase-7 (Casp7) & Haemaphysalis longicornis & 4.54 & 3.66 & 4.10 \\
\hline & Contig392 & Putative acid phosphatise (Papl), Metallophosphoesterase superfamily, Purple acid phosphatase family & Branchiostoma floridae & 4.01 & 2.70 & 3.35 \\
\hline & Contig2589 & Putative gamma-glutamyl hydrolase (GGH) & Saccoglossus kowalevskii & 3.05 & 2.74 & 2.89 \\
\hline Cytoskeleton & Contig5040 & Putative microtubule-associated proteins $1 \mathrm{~A} / 1 \mathrm{~B}$ light chain $3 \mathrm{C}$ (MAP1LC3C) & Hydra magnipapillata & 3.02 & 3.00 & 3.01 \\
\hline \multirow[t]{8}{*}{ Defense mechanisms } & Contig4907 & Putative antimicrobial peptide, Microplusin-like & Ornithodoros coriaceus & 5.82 & 4.48 & 5.15 \\
\hline & Contig4731 & Putative antimicrobial peptide, Microplusin-like & Argas monolakensis & 6.21 & 4.00 & 5.11 \\
\hline & TC21607 & Putative histamine binding protein (HBP), Lipocalin, Calycin superfamily & Rhipicephalus sanguineus & 5.92 & 4.20 & 5.06 \\
\hline & Contig5662 & Putative cystatin, Reversible papain-like cysteine protease inhibitor family & Haemaphysalis longicornis & 5.93 & 4.08 & 5.00 \\
\hline & Contig1086 & Putative serpin, Serine protease inhibitor, Serpin family, Ov-serpin subfamily & Amblyomma americanum & 5.59 & 4.23 & 4.91 \\
\hline & CV444905 & Putative cystatin, Reversible papain-like cysteine protease inhibitor family & Haemaphysalis longicornis & 4.97 & 4.06 & 4.52 \\
\hline & Contig5243 & Putative antimicrobial peptide, Microplusin-like & Ornithodoros coriaceus & 5.51 & 3.33 & 4.42 \\
\hline & TC22004 & Putative serine proteinase inhibitor, Boophilin, Kunitz family & Boophilus microplus & 4.92 & 3.61 & 4.26 \\
\hline
\end{tabular}




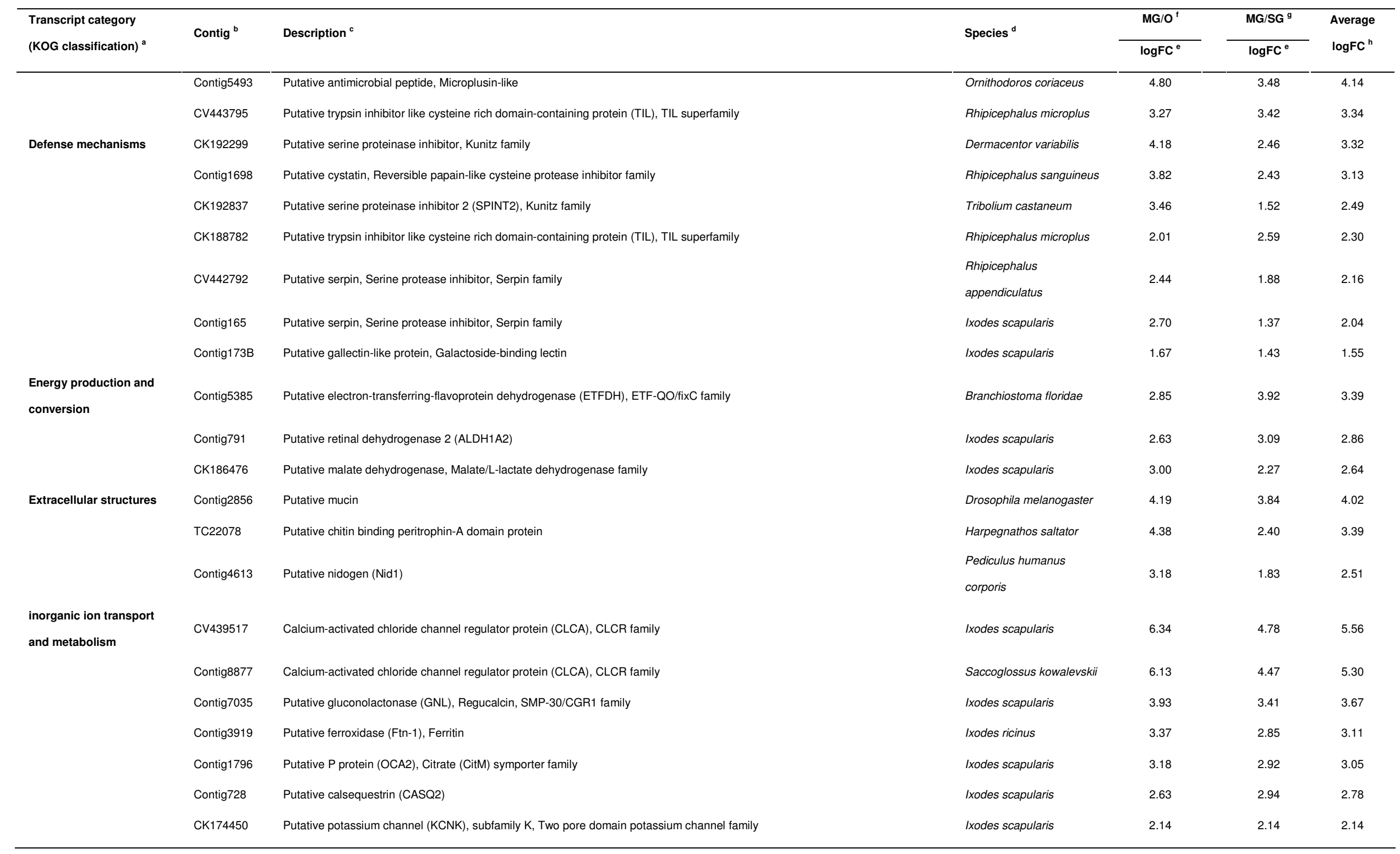




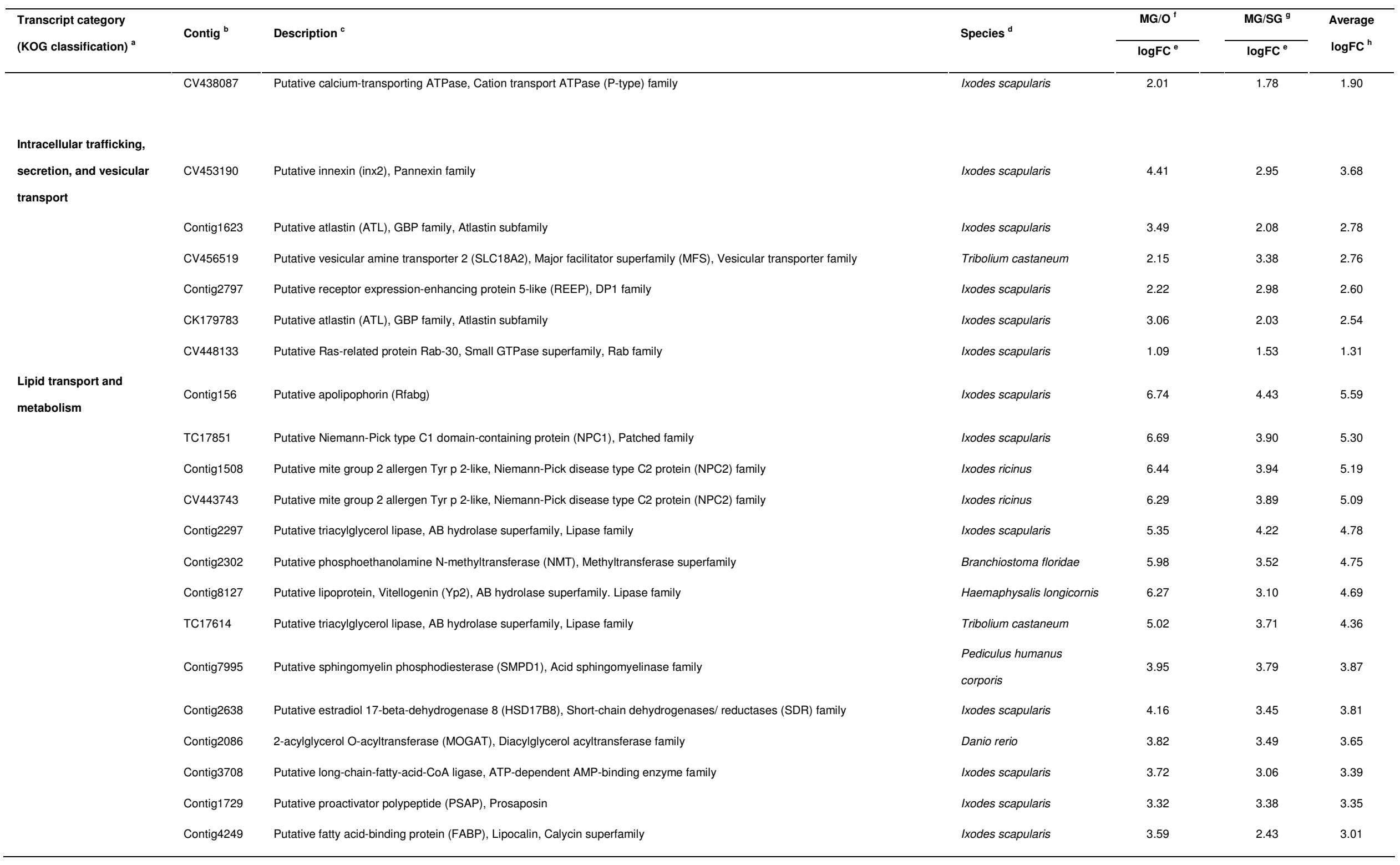




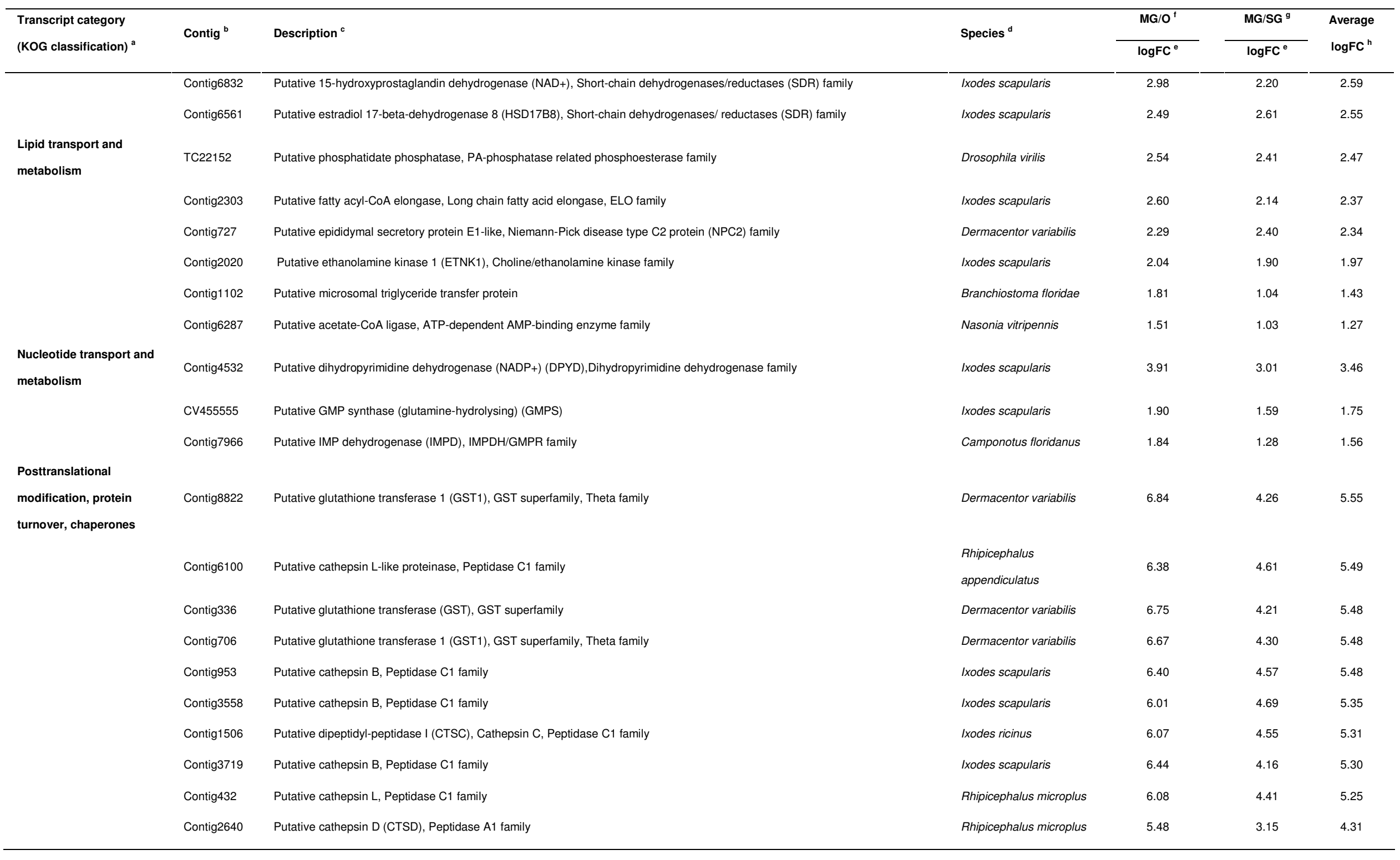




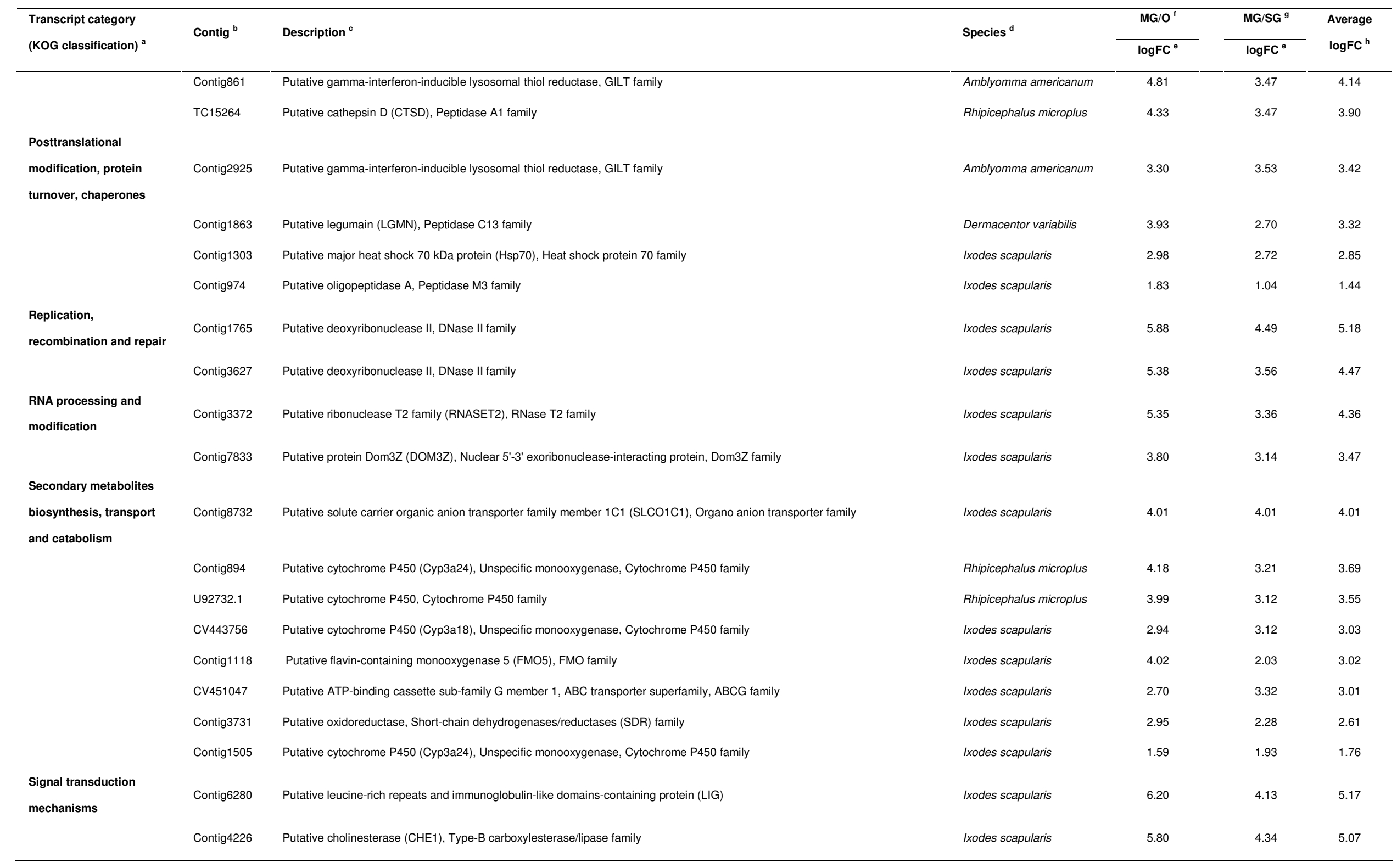




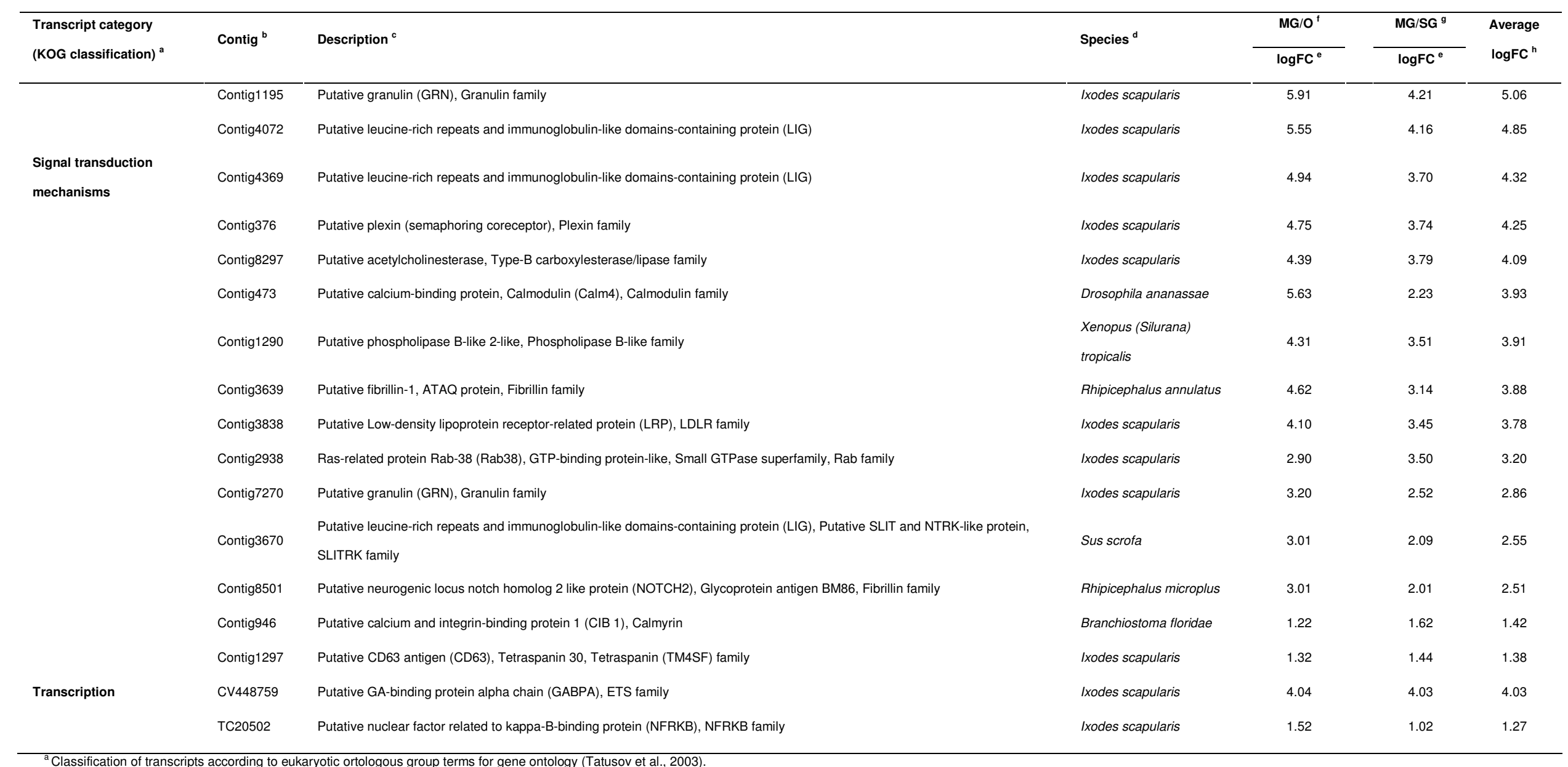

${ }^{\mathrm{b}}$ Assigned contiguous sequence identification for transcripts following assembly of all available expressed sequence tags and the R. microplus Gene Index version 2.1.

' The functional annotation of genes based on comparison of BLAST outputs from seven databases outlined in Section 2.4. All transcript descriptions are based on consensus with database entries from Uniprot (http://www.uniprot.org/uniprot/) and BRENDA

(http://www.brenda-enzymes.org/), in the case of enzymes.

${ }^{\mathrm{S}}$ Species indicated that showed the highest sequence similarity to R. microplus sequences following non-redundant database (NR) BLAST analysis, independent of final assignment.

${ }^{e} \log _{2}$ expression ratios $(\mathrm{LogFC})$ calculated for group pair-wise comparison, to identify significant differentially expressed transcripts with $P$-values adjusted for multiple comparison false discovery rates.

' $\log _{2}$ expression for group pair-wise comparison between midgut (MG) and ovaries $(\mathrm{O})$. Values of $M G / O>1$ correspond to genes that are more expressed in midgut, whereas $M G / O<1$ correspond to genes that are more expressed in ovaries.

${ }^{9} \mathrm{Log}_{2}$ expression for group pair-wise comparison between midgut (MG) and salivary glands (SG). Values of $\mathrm{MG} / \mathrm{SG}>1$ correspond to genes that are more expressed in midgut, whereas $\mathrm{MG} / \mathrm{SG}<1$ correspond to genes that are more expressed in salivary glands. 
Supplementary Table S5. Unique transcripts expressed in ovary tissues of feeding Rhipicephalus microplus female ticks $(P \leq 0.001)$ identified from microarray analysis. Transcripts were chosen using an intensity threshold of 1,000 and an absolute two-fold change regulation of genes relative to other tissues tested.

\begin{tabular}{|c|c|c|c|c|c|c|}
\hline $\begin{array}{l}\text { Transcript category } \\
\text { (KOG classification) }\end{array}$ & Contig $^{b}$ & Description $^{\mathrm{c}}$ & Species $^{d}$ & \begin{tabular}{|l}
$\mathrm{MG} / \mathrm{O}^{f}$ \\
$\log \mathrm{FC}$ \\
\end{tabular} & $\begin{array}{l}\mathrm{O} / \mathrm{SG}^{9} \\
\log \mathrm{FC}^{\mathrm{e}}\end{array}$ & $\begin{array}{r}\text { Avarege } \\
\log \mathrm{FC}^{\mathrm{h}}\end{array}$ \\
\hline \multirow[t]{6}{*}{$\begin{array}{l}\text { Amino acid transport and } \\
\text { metabolism }\end{array}$} & Contig6991 & Putative Ovochymase-2 (OVCH2), Oviductin, Peptidase S1 family & Tetraodon nigroviridis & -6.44 & 3.16 & 4.80 \\
\hline & Contig2561 & Putative transmembrane protease serine 6 (Tmprss6), Peptidase $\mathrm{S} 1$ family & Tetraodon nigroviridis & -6.09 & 2.57 & 4.33 \\
\hline & Contig8156 & Putative serine protease (Stubble), Peptidase S1 family & Ixodes scapularis & -5.12 & 2.51 & 3.81 \\
\hline & Contig3834 & Putative serine carboxypeptidase CPVL (CPVL), Peptidase S10 family & Ixodes scapularis & -3.87 & 1.65 & 2.76 \\
\hline & Contig6628 & Putative neprilysin (NEP2), Peptidase M13 family & Ixodes scapularis & -3.28 & 1.31 & 2.30 \\
\hline & Contig1302 & Putative sodium-coupled neutral amino acid transporter 7 (SLC38A7), Amino acid/polyamine transporter 2 family & Ixodes scapularis & -2.83 & 1.72 & 2.27 \\
\hline \multirow{5}{*}{$\begin{array}{l}\text { Carbohydrate transport } \\
\text { and metabolism }\end{array}$} & Contig2393 & Putative glycoprotein 3-alpha-L-fucosyltransferase, Glycosyltransferase 10 family & Ixodes scapularis & -3.29 & 1.95 & 2.62 \\
\hline & Contig46A & Putative N-acetyllactosaminide beta-1,3-N-acetylglucosaminyltransferase (B3gnt1 ), Glycosyltransferase Family 49 & Ixodes scapularis & -3.23 & 1.67 & 2.45 \\
\hline & Contig7812 & Putative sulfatase- 1 (sulf1), Sulfatase family & Ixodes scapularis & -1.96 & 1.19 & 1.58 \\
\hline & Contig1898 & Putative glycoprotein 3-alpha-L-fucosyltransferase, Glycosyltransferase 10 family & Ixodes scapularis & -1.49 & 1.16 & 1.32 \\
\hline & Contig7288 & Putative anhydro-N-acetylmuramic acid kinase-like protein (anmKI), Anhydro-N-acetylmuramic acid kinase family & Ixodes scapularis & -1.39 & 1.21 & 1.30 \\
\hline \multicolumn{7}{|l|}{ Cell cycle control, cell } \\
\hline \multirow{6}{*}{$\begin{array}{l}\text { division, chromosome } \\
\text { partitioning }\end{array}$} & CV451547 & Putative G2/mitotic-specific cyclin-B2 (ccnb2), Cyclin family, Cyclin AB subfamily & Ixodes scapularis & -3.50 & 2.17 & 2.84 \\
\hline & Contig347 & $\begin{array}{l}\text { Putative non-specific serine/threonine protein kinase (AURKA), Aurora kinase A, Protein kinase superfamily, Ser/Thr protein } \\
\text { kinase family, Aurora subfamily }\end{array}$ & Ixodes scapularis & -2.83 & 1.74 & 2.29 \\
\hline & Contig6020 & Putative coiled-coil domain-containing protein 99 (ccdc99), Protein Spindly, Spindly family & Equus caballus & -2.33 & 1.89 & 2.11 \\
\hline & Contig3041 & Putative actin-binding protein anillin (ANLN) & Ixodes scapularis & -2.52 & 1.31 & 1.92 \\
\hline & Contig4926 & Putative $\mathrm{RCC} 1$ and $\mathrm{BTB}$ domain-containing protein 1 (Rcbtb1) & Ixodes scapularis & -2.05 & 1.44 & 1.75 \\
\hline & Contig7399 & Putative centriolar coiled-coil protein of $110 \mathrm{kDa}$ (CNTRL), Centriolin & Branchiostoma floridae & -1.96 & 1.52 & 1.74 \\
\hline
\end{tabular}




\begin{tabular}{|c|c|c|c|c|c|c|}
\hline \multirow[t]{2}{*}{ 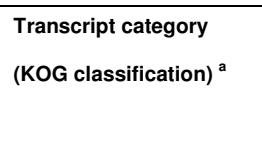 } & Contig $^{b}$ & Description $^{c}$ & Species $^{d}$ & $\begin{array}{l}\mathrm{MG} / \mathrm{O}^{f} \\
\log \mathrm{FC} \\
\end{array}$ & $\begin{array}{c}\mathrm{O} / \mathrm{SG}^{9} \\
\log \mathrm{FC}^{\mathrm{e}}\end{array}$ & $\begin{array}{c}\text { Avareg } \\
\log \mathrm{FC}^{h}\end{array}$ \\
\hline & Contig7206 & Putative microtubule-severing ATPase (SPAST), Spastin, AAA ATPase family, Spastin subfamily & Ixodes scapularis & -2.02 & 1.35 & 1.69 \\
\hline \multicolumn{7}{|l|}{ Cell cycle control, cell } \\
\hline \multirow{8}{*}{$\begin{array}{l}\text { division, chromosome } \\
\text { partitioning }\end{array}$} & Contig580 & Putative protein-tyrosine-phosphatase (CDC25C), M-phase inducer phosphatase 3, MPI phosphatase family & Ixodes scapularis & -2.03 & 1.32 & 1.68 \\
\hline & Contig7241 & Putative G2/mitotic-specific cyclin-B3 (CycB3), Cyclin family, Cyclin AB subfamily & Ixodes scapularis & -2.19 & 1.14 & 1.67 \\
\hline & Contig1139 & Putative microtubule-severing ATPase (SPAST), Spastin, AAA ATPase family, Spastin subfamily & Ixodes scapularis & -1.36 & 1.70 & 1.53 \\
\hline & CV446249 & Putative cyclin-dependent kinase 14 (CDK14) & Culex quinquefasciatus & -1.85 & 1.21 & 1.53 \\
\hline & Contig2477 & Putative piwi-like protein 1 , Argonaute family, Piwi subfamily & Ixodes scapularis & -1.51 & 1.08 & 1.29 \\
\hline & EW679192.1 & Putative mediator of DNA damage checkpoint protein 1 (MDC1) & Rattus norvegicus & -1.38 & 1.10 & 1.24 \\
\hline & Contig5545 & Putative mitotic spindle assembly checkpoint protein MAD2B (MAD2L2) & Ixodes scapularis & -1.06 & 1.15 & 1.10 \\
\hline & Contig662 & Putative piwi-like protein 1 , Argonaute family, Piwi subfamily & Ixodes scapularis & -1.05 & 1.15 & 1.10 \\
\hline \multirow{12}{*}{$\begin{array}{l}\text { Cell wall/ membrane/ } \\
\text { envelope biogenesis } \\
\text { Chromatin structure and } \\
\text { dynamics }\end{array}$} & Contig2246 & Putative transmembrane protein 135 -like (Tmem135) & Ixodes scapularis & -4.09 & 2.13 & 3.11 \\
\hline & Contig6410 & Putative histone $\mathrm{H} 3.1$ (HIST1H3F), Histone $\mathrm{H} 3$ family & Canis familiaris & -6.65 & 3.23 & 4.94 \\
\hline & Contig5900 & Putative histone $\mathrm{H} 3.1$ (HIST1H3F), Histone $\mathrm{H} 3$ family & Canis familiaris & -5.84 & 2.97 & 4.41 \\
\hline & TC21623 & Putative histone $\mathrm{H} 2 \mathrm{~A}$, Histone $\mathrm{H} 2 \mathrm{~A}$ family & Caenorhabditis remanei & -4.68 & 2.15 & 3.41 \\
\hline & Contig4221 & Putative histone H2A type 1-D, Histone H2A family & Aplysia californica & -4.44 & 2.28 & 3.36 \\
\hline & CK189050 & Putative transducin-like enhancer protein 4 (TLE4), WD repeat Groucho/TLE family & Ixodes scapularis & -2.61 & 1.69 & 2.15 \\
\hline & Contig6899 & Putative microcephalin (Mcph1) & Ixodes scapularis & -2.51 & 1.77 & 2.14 \\
\hline & Contig5352 & Putative histone $\mathrm{H} 4$ (HIST1H4B), Histone $\mathrm{H} 4$ family & Canis familiaris & -2.36 & 1.45 & 1.90 \\
\hline & Contig4005 & Putative protein groucho 2(GRO2), WD repeat Groucho/TLE family & Ixodes scapularis & -2.06 & 1.33 & 1.70 \\
\hline & Contig2123 & Putative histone $\mathrm{H} 2 \mathrm{~A}$, Histone $\mathrm{H} 2 \mathrm{~A}$ family & Ixodes scapularis & -1.97 & 1.22 & 1.60 \\
\hline & CV457670 & Putative Structural maintenance of chromosomes protein 5 (SMC5), SMC family, SMC5 subfamily & Ixodes scapularis & -1.52 & 1.58 & 1.55 \\
\hline & Contig4071 & Putative Histone H2A.V (H2AFV), Histone H2A family & Dermacentor variabilis & -1.75 & 1.35 & 1.55 \\
\hline Coenzyme transport and & Contig2901 & Putativenicotinate phosphoribosyltransferase (NRPT), NAPRTase family & Ixodes scapularis & -1.41 & 1.19 & 1.30 \\
\hline
\end{tabular}




\begin{tabular}{|c|c|c|c|c|c|c|}
\hline \multirow{2}{*}{$\begin{array}{l}\text { Transcript category } \\
\text { (KOG classification) }^{\text {a }} \\
\text { metabolism }\end{array}$} & \multirow[t]{2}{*}{ Contig $^{b}$} & \multirow[t]{2}{*}{ Description $^{\circ}$} & \multirow[t]{2}{*}{ Species $^{d}$} & \multirow{2}{*}{$\begin{array}{l}\mathrm{MG} / \mathrm{O}^{f} \\
\log \mathrm{FC}^{\mathrm{e}}\end{array}$} & \multirow{2}{*}{$\begin{array}{c}\mathrm{O} / \mathrm{SG}^{9} \\
\log \mathrm{FC}^{\mathrm{e}}\end{array}$} & \multirow[t]{2}{*}{$\begin{array}{l}\text { Avarege } \\
\text { log FC }\end{array}$} \\
\hline & & & & & & \\
\hline $\begin{array}{l}\text { Coenzyme transport and } \\
\text { metabolism }\end{array}$ & Contig7165 & Putative all-trans-decaprenyl-diphosphate synthase subunit 1 (PDSS1), FPP/GGPP synthase family & Gallus gallus & -1.36 & 1.02 & 1.19 \\
\hline \multirow[t]{4}{*}{ Cytoskeleton } & CK177355 & Putative Gamma-tubulin complex component 2 (TUBGCP2), GCP family & $\begin{array}{l}\text { Xenopus (Silurana) } \\
\text { tropicalis }\end{array}$ & -2.93 & 2.09 & 2.51 \\
\hline & CV437181 & Putative KN motif and ankyrin repeat domain-containing protein (KANK) & Ixodes scapularis & -3.13 & 1.35 & 2.24 \\
\hline & Contig5218 & Putative formin 2 protein (FMN2), Formin homology family & Ixodes scapularis & -2.28 & 1.12 & 1.70 \\
\hline & Contig8247 & Putative thymosin beta-4 (TMSB4X), Thymosin beta family & Dermacentor variabilis & -1.01 & 1.01 & 1.01 \\
\hline \multirow[t]{2}{*}{ Defense mechanisms } & Contig104 & Putative peptidase inhibitor 16 (PI16), Cysteine-rich secretory protein family (CRISP) & Ixodes scapularis & -1.20 & 1.93 & 1.56 \\
\hline & Contig1561 & Putative sulfiredoxin (SRXN1), Sulfiredoxin family & Nasonia vitripennis & -1.09 & 1.27 & 1.18 \\
\hline \multirow{3}{*}{$\begin{array}{l}\text { Energy production and } \\
\text { conversion }\end{array}$} & Contig1954 & Putative solute carrier protein family 25 member 16 (SLC25A16), Mitochondrial carrier family & Ixodes scapularis & -2.09 & 1.80 & 1.95 \\
\hline & CV456316 & Putative solute carrier family 25 member 36 (Slc25a36), Mitochondrial carrier family & Nasonia vitripennis & -1.85 & 1.52 & 1.69 \\
\hline & Contig6442 & Putative solute carrier family 25 member 42 (SLC25A42), Mitochondrial carrier family & Ixodes scapularis & -1.62 & 1.38 & 1.50 \\
\hline \multirow[t]{4}{*}{ Extracellular structures } & Contig1170 & Putative mucin & Caenorhabditis remanei & -4.97 & 2.38 & 3.67 \\
\hline & Contig2770 & Putative mucin & Rattus norvegicus & -4.69 & 2.56 & 3.63 \\
\hline & Contig344 & Putative mucin & Saccharomyces cerevisiae & -4.01 & 2.37 & 3.19 \\
\hline & Contig4162 & Putative interphotoreceptor matrix proteoglycan 2 (Impg2), & $\begin{array}{l}\text { Strongylocentrotus } \\
\text { purpuratus }\end{array}$ & -3.29 & 1.97 & 2.63 \\
\hline \multirow{6}{*}{$\begin{array}{l}\text { Inorganic ion transport } \\
\text { and metabolism }\end{array}$} & Contig4603 & Putative transmembrane protein 163 (TMEM163), TMEM163 family & Ixodes scapularis & -4.11 & 2.08 & 3.09 \\
\hline & Contig6386 & Putative Sodium/potassium/calcium exchanger 6 (SLC24A6), Sodium/potassium/calcium exchanger family, SLC24A subfamily & Ixodes scapularis & -3.64 & 1.94 & 2.79 \\
\hline & Contig166 & Putative superoxide dismutase (SOD1), Cu-Zn superoxide dismutase family & Cu-Zn & -3.64 & 1.82 & 2.73 \\
\hline & CK173943 & Putative calcium-activated chloride channel regulator protein (CLCA), CLCR family & Saccoglossus kowalevskii & -3.52 & 1.60 & 2.56 \\
\hline & CK188814 & Putative prestin (SIc26a5), solute carrier family 26 member 5, SLC26A/SulP transporter family & Ixodes scapularis & -2.64 & 1.89 & 2.26 \\
\hline & Contig180A & Putative selenium-binding protein 1 (SELENBP1), Selenium-binding protein family & Xenopus laevis & -2.42 & 2.05 & 2.23 \\
\hline
\end{tabular}




\begin{tabular}{|c|c|c|c|c|c|c|}
\hline \multirow[t]{2}{*}{$\begin{array}{l}\text { Transcript category } \\
\text { (KOG classification) }^{\text {a }}\end{array}$} & \multirow{2}{*}{$\begin{array}{l}\text { Contig }^{\text {b }} \\
\text { CV448303 }\end{array}$} & \multirow{2}{*}{$\begin{array}{l}\text { Description }^{\mathrm{c}} \\
\text { Putative sodium bicarbonate transporter-like protein } 11 \text { (SLC4A11), Anion exchanger family }\end{array}$} & \multirow{2}{*}{$\begin{array}{l}\text { Species }^{\text {d }} \\
\text { Ixodes scapularis }\end{array}$} & \multirow{2}{*}{$\begin{array}{c}\mathrm{MG} / \mathrm{O}^{f} \\
\log \mathrm{CC}^{\mathrm{e}} \\
-2.79\end{array}$} & \multirow{2}{*}{$\begin{array}{c}\mathrm{O} / \mathrm{SG}^{\mathrm{g}} \\
\log \mathrm{FC}^{\mathrm{e}} \\
1.44\end{array}$} & \multirow{2}{*}{$\begin{array}{r}\text { Avarege } \\
\text { logFC } \\
2.12\end{array}$} \\
\hline & & & & & & \\
\hline \multirow[t]{2}{*}{$\begin{array}{l}\text { Inorganic ion transport } \\
\text { and metabolism }\end{array}$} & CV453301 & Putative zinc transporter SLC39A7 & Ixodes scapularis & -2.09 & 1.58 & 1.83 \\
\hline & Contig70 & Putative organic cation transporter-like protein (Orct2), Major facilitator superfamily (MFS), Organic cation transporter family & Ixodes scapularis & -1.72 & 1.01 & 1.37 \\
\hline \multirow{12}{*}{$\begin{array}{l}\text { Intracellular trafficking, } \\
\text { secretion, and vesicular } \\
\text { transport }\end{array}$} & & & & & & \\
\hline & Contig443 & Putative clavesin-2 (CLVS2), Retinaldehyde-binding protein 1-like 2 & Ixodes scapularis & -4.54 & 2.52 & 3.53 \\
\hline & Contig1785 & Putative tether containing UBX domain for GLUT4 (TUG) & $\begin{array}{l}\text { Pediculus humanus } \\
\text { corporis }\end{array}$ & -1.45 & 1.34 & 1.39 \\
\hline & Contig8621 & Putative sorting nexin 21 (SNX21), Sorting nexin family & Ixodes scapularis & -1.76 & 1.00 & 1.38 \\
\hline & Contig932 & Putative conserved oligomeric Golgi complex subunit 4 (COG4), COG4 family & Ixodes scapularis & -1.39 & 1.37 & 1.38 \\
\hline & Contig3868 & Putative maspardin (SPG21), AB hydrolase superfamily & Branchiostoma floridae & -1.08 & 1.64 & 1.36 \\
\hline & Contig4380 & Putative Lateral signalling target protein 2 homolog (ZFYVE28), Zinc finger FYVE domain-containing protein 28 & Ixodes scapularis & -1.30 & 1.14 & 1.22 \\
\hline & Contig5056 & Putative Ankyrin repeat and FYVE domain-containing protein 1 (ANKFY1) & Ixodes scapularis & -1.09 & 1.20 & 1.15 \\
\hline & Contig5948 & Putative exocyst complex component 6 (SEC6), SEC6 family & Branchiostoma floridae & -1.16 & 1.11 & 1.14 \\
\hline & Contig8390 & Putative sorting nexin-33 (SNX33), Sorting nexin family & $\begin{array}{l}\text { Pediculus humanus } \\
\text { corporis }\end{array}$ & -1.03 & 1.20 & 1.12 \\
\hline & CK177961 & Putative CHMP family member 7 (CHMP7), SNF7 family & Ixodes scapularis & -1.18 & 1.03 & 1.10 \\
\hline & Contig1237 & Putative vesicle transport protein (USE1), USE1 family & Ixodes scapularis & -1.30 & 1.04 & 1.17 \\
\hline \multirow{7}{*}{$\begin{array}{l}\text { Lipid transport and } \\
\text { metabolism }\end{array}$} & Contig276 & Putative Low-density lipoprotein receptor-related protein 4 (LRP4), Putative vitellogenin receptor, LDLR family & Dermacentor variabilis & -5.45 & 3.04 & 4.24 \\
\hline & CK185778 & Putative 3-ketoacyl-CoA synthase (Elov17), ELO family & Ixodes scapularis & -5.80 & 2.66 & 4.23 \\
\hline & Contig97 & Putative 3-ketoacyl-CoA synthase (Elov11), ELO family & Ixodes scapularis & -5.21 & 2.37 & 3.79 \\
\hline & Contig2240 & Putative $A B C$ transporter $A$ family member 1 ( $A B C A 1$ ), $A B C$ transporter superfamily, $A B C A$ family & Ixodes scapularis & -5.07 & 2.47 & 3.77 \\
\hline & Contig190A & Putative 3-ketoacyl-CoA synthase (Elov14), ELO family & Ixodes scapularis & -4.89 & 2.28 & 3.58 \\
\hline & Contig6191 & Putative ABC transporter $G$ family member 20 (abcG20), ABC transporter superfamily, ABCG family & Ixodes scapularis & -4.47 & 2.23 & 3.35 \\
\hline & Contig1782 & Putative 3-ketoacyl-CoA synthase (Elov11), ELO family & Ixodes scapularis & -3.87 & 1.95 & 2.91 \\
\hline
\end{tabular}




\begin{tabular}{|c|c|c|c|c|c|c|}
\hline \multirow[t]{2}{*}{$\begin{array}{l}\text { Transcript category } \\
\text { (KOG classification) }^{\text {a }}\end{array}$} & \multirow{2}{*}{$\begin{array}{l}\text { Contig }^{b} \\
\text { Contig969 }\end{array}$} & \multirow{2}{*}{$\begin{array}{l}\text { Description }^{c} \\
\text { Putative long-chain-fatty-acid-CoA ligase }\end{array}$} & \multirow{2}{*}{$\begin{array}{l}\text { Species }^{d} \\
\text { Ixodes scapularis }\end{array}$} & \multirow{2}{*}{$\begin{array}{c}\mathrm{MG} / \mathrm{O}^{f} \\
\log \mathrm{FC}^{\mathrm{e}} \\
-2.72\end{array}$} & \multirow{2}{*}{$\begin{array}{c}\mathrm{O} / \mathrm{SG}^{\mathrm{g}} \\
\log ^{\mathrm{F} \mathrm{C}^{\mathrm{e}}} \\
2.38\end{array}$} & \multirow{2}{*}{$\begin{array}{r}\text { Avarege } \\
\log ^{2} \mathrm{FC}^{\mathrm{h}} \\
\\
2.55\end{array}$} \\
\hline & & & & & & \\
\hline \multirow{6}{*}{$\begin{array}{l}\text { Lipid transport and } \\
\text { metabolism }\end{array}$} & Contig1663 & Putative Fatty acyl-CoA reductase 1 (FAR1), Fatty acyl-CoA reductase family & Ixodes scapularis & -2.85 & 1.49 & 2.17 \\
\hline & CK177193 & Putative triacylglycerol lipase, AB hydrolase superfamily, Lipase family & Ixodes scapularis & -2.69 & 1.54 & 2.12 \\
\hline & Contig2678 & $\begin{array}{l}\text { Putative peroxisomal multifunctional enzyme type } 2 \text { (HSD17B4), 17-beta-hydroxysteroid dehydrogenase 4, Short-chain } \\
\text { dehydrogenases/reductases (SDR) family }\end{array}$ & Ixodes scapularis & -1.95 & 1.49 & 1.72 \\
\hline & Contig814 & $\begin{array}{l}\text { Putative peroxisomal multifunctional enzyme type } 2 \text { (HSD17B4), 17-beta-hydroxysteroid dehydrogenase 4, Short-chain } \\
\text { dehydrogenases/reductases (SDR) family }\end{array}$ & Ixodes scapularis & -2.24 & 1.18 & 1.71 \\
\hline & Contig8307 & Putative inositol-polyphosphate 5-phosphatase (INPP5A),Inositol 1,4,5-trisphosphate 5-phosphatase type I family & Ixodes scapularis & -1.78 & 1.43 & 1.61 \\
\hline & CK183268 & $\begin{array}{l}\text { Putative protein-tyrosine-phosphatase, Myotubularin-related protein } 3 \text { (MTMR3), Protein-tyrosine phosphatase family, Non- } \\
\text { receptor class myotubularin subfamily }\end{array}$ & Ixodes scapularis & -1.61 & 1.53 & 1.57 \\
\hline \multirow{12}{*}{$\begin{array}{l}\text { Nuclear structure } \\
\text { Nucleotide transport and } \\
\text { metabolism } \\
\text { Posttranslational } \\
\text { modification, protein } \\
\text { turnover, chaperones }\end{array}$} & Contig1959 & Putative nucleoporin (NDC1), Transmembrane protein 48 (TMEM48), NDC1 family & Homo sapiens & -1.41 & 1.03 & 1.22 \\
\hline & Contig18 & Putative hypoxanthine phosphoribosyltransferase (HPRT), Purine/pyrimidine phosphoribosyltransferase family & Ictalurus punctatus & -2.34 & 1.04 & 1.69 \\
\hline & & & & & & \\
\hline & CK180207 & Putative protein disulfide-isomerase (PDI2), Protein disulfide isomerase family & Haemaphysalis longicornis & -5.31 & 2.71 & 4.01 \\
\hline & Contig5413 & Putative protein disulfide-isomerase (PDI2), Protein disulfide isomerase family & Ixodes scapularis & -5.29 & 2.72 & 4.00 \\
\hline & Contig1209 & Putative cathepsin L (CTSL), Peptidase C1 family & $\begin{array}{l}\text { Rhipicephalus } \\
\text { appendiculatus }\end{array}$ & -5.00 & 2.88 & 3.94 \\
\hline & Contig1826 & Putative glutathione transferase (GSTE3), GST superfamily & Dermacentor variabilis & -3.95 & 3.20 & 3.57 \\
\hline & Contig2266 & Putative alpha-2-macroglobulin (CD109), Protease inhibitor 139 (alpha-2-macroglobulin) family & Ixodes scapularis & -4.71 & 1.88 & 3.30 \\
\hline & Contig8445 & Putative disintegrin and metalloproteinase with thrombospondin motifs (ADAMTS)-like protein 5 (ADAMTSL5) & $\begin{array}{l}\text { Xenopus (Silurana) } \\
\text { tropicalis }\end{array}$ & -3.48 & 2.17 & 2.83 \\
\hline & Contig1441 & Putative astacin (nas36), Peptidase M12A family & Ixodes scapularis & -3.37 & 1.33 & 2.35 \\
\hline & CK187103 & Putative alpha-2-macroglobulin receptor-associated protein (Lrpap1), Alpha-2-MRAP family & Ixodes scapularis & -2.29 & 1.94 & 2.11 \\
\hline & Contig8502 & Putative chitobiosyldiphosphodolichol beta-mannosyltransferase (ALG1), Glycosyltransferase group 1 family, Glycosyltransferase & Trichoplax adhaerens & -2.02 & 1.82 & 1.92 \\
\hline
\end{tabular}




\begin{tabular}{|c|c|c|c|c|c|c|}
\hline \multirow[t]{2}{*}{$\begin{array}{l}\text { Transcript category } \\
\text { (KOG classification) }^{\text {a }}\end{array}$} & \multirow[t]{2}{*}{ Contig $^{b}$} & \multirow{2}{*}{$\begin{array}{l}\text { Description }^{\circ} \\
33 \text { subfamily }\end{array}$} & \multirow[t]{2}{*}{ Species $^{d}$} & $\begin{array}{c}\mathrm{MG} / \mathrm{O}^{f} \\
\log \mathrm{FC}^{\mathrm{e}}\end{array}$ & \multirow[t]{2}{*}{$\begin{array}{l}\mathrm{O} / \mathrm{SG}^{g} \\
\operatorname{logFC}{ }^{e}\end{array}$} & \multirow[t]{2}{*}{$\begin{array}{l}\text { Avarege } \\
\text { logFC }\end{array}$} \\
\hline & & & & & & \\
\hline \multirow{20}{*}{$\begin{array}{l}\text { Posttranslational } \\
\text { modification, protein } \\
\text { turnover, chaperones }\end{array}$} & & & & & & \\
\hline & Contig8117 & Putative ubiquitinyl hydrolase 1 (Usp47), Peptidase C19 family, USP47 subfamily & Mus musculus & -1.98 & 1.60 & 1.79 \\
\hline & Contig3354 & Putative DnaJ-like protein subfamily A member 1 (DNAJA1), DnaJ superfamily & Camponotus floridanus & -2.15 & 1.27 & 1.71 \\
\hline & Contig204 & Putative ubiquitinyl hydrolase 1 (USP22), Peptidase C19 family, UBP8 subfamily & Ixodes scapularis & -2.05 & 1.24 & 1.64 \\
\hline & Contig7869 & Putative E3 ubiquitin-protein ligase 3 (MARCH3) & Ixodes scapularis & -2.15 & 1.10 & 1.62 \\
\hline & Contig3925 & Putative glutathione transferase (GSTM), GST superfamily, Mu family & $\begin{array}{l}\text { Rhipicephalus } \\
\text { appendiculatus }\end{array}$ & -1.72 & 1.51 & 1.61 \\
\hline & CV436862 & Putative ubiquitinyl hydrolase 1 (USP36), Peptidase C19 family & Ixodes scapularis & -1.66 & 1.47 & 1.57 \\
\hline & Contig3668 & Putative S-phase kinase-associated protein 1 (SKP1), SKP1 family & Ixodes scapularis & -1.92 & 1.16 & 1.54 \\
\hline & Contig3190 & Putative E3 ubiquitin protein ligase TRIP12 (TRIP12), UPL family, K-HECT subfamily & Ailuropoda melanoleuca & -1.92 & 1.16 & 1.54 \\
\hline & Contig8986 & Putative small ubiquitin-related modifier 1 (SUMO1), Ubiquitin family, SUMO subfamily & Ixodes scapularis & -1.72 & 1.25 & 1.48 \\
\hline & CV441669 & Putative endoplasmin (HSP90B1), Heat shock protein 90 family & Ixodes scapularis & -1.28 & 1.37 & 1.32 \\
\hline & CK184440 & Putative ubiquitinyl hydrolase 1 (USP10), Peptidase C19 family, USP10 subfamily & $\begin{array}{l}\text { Strongylocentrotus } \\
\text { purpuratus }\end{array}$ & -1.03 & 1.20 & 1.11 \\
\hline & Contig8510 & Putative DnaJ homolog subfamily C member 21 (DNAJC21), DnaJ superfamily & $\begin{array}{l}\text { Xenopus (Silurana) } \\
\text { tropicalis }\end{array}$ & -1.15 & 1.07 & 1.11 \\
\hline & Contig2063 & Putative endoplasmin (HSP90B1), Heat shock protein 90 family & Ixodes scapularis & -1.09 & 1.10 & 1.10 \\
\hline & TC15194 & Putative Ulp1 peptidase (SENP1), Sentrin-specific protease 1, Peptidase C48 family & Ixodes scapularis & -1.13 & 1.05 & 1.09 \\
\hline & Contig2862 & Putative heat shock protein HSP 90-alpha (HSP90AA1), Heat shock protein 90 family & Ixodes scapularis & -1.08 & 1.01 & 1.05 \\
\hline & CK180163 & Putative E3 ubiquitin-protein ligase KCMF1, KCMF1 family & Nasonia vitripennis & -1.76 & 1.25 & 1.51 \\
\hline & Contig3713 & Putative G2/M phase-specific E3 ubiquitin-protein ligase (G2E3) & Branchiostoma floridae & -1.58 & 1.00 & 1.29 \\
\hline & Contig8369 & Putative Kelch-like protein 20 (KLHL20), Kelch-like protein diablo & Ixodes scapularis & -1.31 & 1.25 & 1.28 \\
\hline & CV452499 & Putative protein cereblon (CRBN), CRBN family & Ixodes scapularis & -1.02 & 1.05 & 1.04 \\
\hline $\begin{array}{l}\text { Replication, } \\
\text { recombination and repair }\end{array}$ & Contig5833 & Putative PCNA-associated factor (PAF) & Ictalurus furcatus & -3.62 & 2.26 & 2.94 \\
\hline
\end{tabular}




\begin{tabular}{|c|c|c|c|c|c|c|}
\hline \multirow[t]{2}{*}{$\begin{array}{l}\text { Transcript category } \\
\text { (KOG classification) }^{\mathrm{a}}\end{array}$} & \multirow{2}{*}{$\begin{array}{l}\text { Contig }^{b} \\
\text { Contig7899 }\end{array}$} & \multirow{2}{*}{$\begin{array}{l}\text { Description }^{c} \\
\text { Putative DNA excision repair protein ERCC-6 (ERCC6) }\end{array}$} & \multirow{2}{*}{$\begin{array}{l}\text { Species }^{\text {d }} \\
\text { Ixodes scapularis }\end{array}$} & \multirow{2}{*}{$\begin{array}{c}\mathrm{MG} / \mathrm{O}^{f} \\
\log \mathrm{FC}^{\mathrm{e}} \\
-3.14\end{array}$} & \multirow{2}{*}{$\begin{array}{c}\mathrm{O}^{\mathrm{SG}}{ }^{\mathrm{g}} \\
\mathrm{logFC}^{\mathrm{e}} \\
2.17\end{array}$} & \multirow{2}{*}{$\begin{array}{r}\text { Avarege } \\
\log \mathrm{FC}^{\mathrm{h}} \\
2.66\end{array}$} \\
\hline & & & & & & \\
\hline \multirow{6}{*}{$\begin{array}{l}\text { Replication, } \\
\text { recombination and repair }\end{array}$} & CV454785 & Putative protein DBF4 homolog A (DBF4) & Ixodes scapularis & -2.01 & 1.91 & 1.96 \\
\hline & Contig6830 & Putative PAP-associated domain-containing protein 5 (PAPD5), DNA polymerase type-B-like family & Ixodes scapularis & -2.22 & 1.42 & 1.82 \\
\hline & Contig6802 & Putative PCNA-associated factor (PAF) & Ictalurus furcatus & -1.97 & 1.25 & 1.61 \\
\hline & CK189318 & Putative Retrotransposable element T†2 $155 \mathrm{kDa}$ protein type $3(\mathrm{~T} \uparrow 2-11)$ & Ixodes scapularis & -1.51 & 1.37 & 1.44 \\
\hline & Contig7868 & Putative Replication protein A $70 \mathrm{kDa}$ DNA-binding subunit (RPA1), Replication factor A protein 1 family & Callithrix jacchus & -1.53 & 1.00 & 1.27 \\
\hline & CK187178 & Putative cell cycle checkpoint protein RAD17 (RAD17), Rad17/RAD24 family & Ixodes scapularis & -1.13 & 1.08 & 1.10 \\
\hline \multirow{8}{*}{$\begin{array}{l}\text { RNA processing and } \\
\text { modification }\end{array}$} & Contio7706 & & 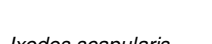 & 17 & 218 & 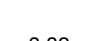 \\
\hline & Contig383 & Putative protein bicaudal $\mathrm{C}$ homolog 1 (BICC1), BicC family & Ixodes scapularis & -3.81 & 2.47 & 3.14 \\
\hline & Contig621 & Putative RNA helicase (MOV10), DNA2/NAM7 helicase family, SDE3 subfamily & Ixodes scapularis & -3.01 & 2.17 & 2.59 \\
\hline & Contig5328 & Putative RNA-binding protein MEX3B (MEX3B) & Apis mellifera & -2.57 & 1.44 & 2.01 \\
\hline & CK191584 & Putative RNA helicase (DDX4), DEAD box helicase family, DDX4/VASA subfamily & Botryllus primigenus & -2.07 & 1.74 & 1.90 \\
\hline & Contig1284 & Putative RNA helicase (DDX4), DEAD box helicase family, DDX4/NASA subfamily & Ixodes scapularis & -2.08 & 1.34 & 1.71 \\
\hline & CV442379 & Putative RNA-directed RNA polymerase (RDR), RdRP family & Ixodes scapularis & -1.69 & 1.52 & 1.61 \\
\hline & Contig4795 & Putative ATP-dependent RNA helicase (DDX31), DEAD box helicase family, DDX31/DBP7 subfamily & $\begin{array}{l}\text { Xenopus (Silurana) } \\
\text { tropicalis }\end{array}$ & -1.63 & 1.33 & 1.48 \\
\hline \multicolumn{7}{|l|}{ Secondary metabolites } \\
\hline \multirow{2}{*}{$\begin{array}{l}\text { biosynthesis, transport } \\
\text { and catabolism }\end{array}$} & CK173094 & Putative 11-cis-retinol dehydrogenase (Rdh1), Short-chain dehydrogenases/reductases (SDR) family & Ixodes scapularis & -2.16 & 1.58 & 1.87 \\
\hline & Contig6553 & Putative mitochondrial substrate carrier family protein, Solute carrier family 25 member 51 (SLC25A), Mitochondrial carrier family & Ixodes scapularis & -1.94 & 1.19 & 1.56 \\
\hline \multirow{4}{*}{$\begin{array}{l}\text { Signal transduction } \\
\text { mechanisms }\end{array}$} & Contig4236 & Putative polo-like kinase (PLK), Protein kinase superfamily, Ser/Thr protein kinase family, CDC5/Polo subfamily & Gallus gallus & -4.79 & 2.82 & 3.80 \\
\hline & CK181827 & Putative CD82 antigen, Tetraspanin-27, Tetraspanin (TM4SF) family & Ixodes scapularis & -2.82 & 1.43 & 2.12 \\
\hline & CK179648 & Putative PTB domain-containing engulfment adapter protein 1 (CED-6), Ced-6 family & Ixodes scapularis & -2.34 & 1.64 & 1.99 \\
\hline & CV447216 & Putative Rho GTPase-activating protein 20 (ARHGAP20) & Ixodes scapularis & -2.28 & 1.66 & 1.97 \\
\hline
\end{tabular}




\begin{tabular}{|c|c|c|c|c|c|c|}
\hline $\begin{array}{l}\text { Transcript category } \\
\text { (KOG classification) }^{\text {a }}\end{array}$ & Contig $^{b}$ & Description $^{\mathrm{C}}$ & Species $^{d}$ & \begin{tabular}{|l|}
$\mathrm{MG} / \mathrm{O}^{f}$ \\
$\log \mathrm{FC}$ \\
\end{tabular} & $\begin{array}{l}\mathrm{O} / \mathrm{SG}^{9} \\
\operatorname{logFC}^{\mathrm{e}}\end{array}$ & $\begin{array}{l}\text { Avarege } \\
\text { log } \mathrm{FC}^{\text {h }}\end{array}$ \\
\hline \multirow[t]{15}{*}{$\begin{array}{l}\text { Signal transduction } \\
\text { mechanisms }\end{array}$} & CK189238 & $\begin{array}{l}\text { Putative non-specific serine/threonine protein kinase (CHEK1), Protein kinase superfamily, CAMK Ser/Thr protein kinase family, } \\
\text { NIM1 subfamily }\end{array}$ & Ornithorhynchus anatinus & -2.42 & 1.46 & 1.94 \\
\hline & Contig6669 & Putative GTP-binding protein Rit1 (RIT1), Small GTPase superfamily, Ras family & Ixodes scapularis & -2.25 & 1.53 & 1.89 \\
\hline & Contig551 & Putative discs large-associated protein 5 (DAP-5), SAPAP family & Ixodes scapularis & -1.97 & 1.79 & 1.88 \\
\hline & CV451440 & Putative Rho GTPase-activating protein 20 (ARHGAP20) & Ixodes scapularis & -2.27 & 1.43 & 1.85 \\
\hline & CV444241 & Putative Kelch-like protein 2 (KLHL2), Mayven & Ixodes scapularis & -2.24 & 1.38 & 1.81 \\
\hline & Contig4788 & Putative protein kinase $\mathrm{R}$ (PRKR)-interacting protein 1 (PRKRIP1), PRKRIP1 family & Ixodes scapularis & -1.98 & 1.48 & 1.73 \\
\hline & Contig3355 & Putative protein-tyrosine-phosphatase (TPTE) & Ixodes scapularis & -1.35 & 2.07 & 1.71 \\
\hline & Contig6510 & Putative GRB2-associated-binding protein 2 (Gab2), Protein daughter of sevenless (dos) & Ixodes scapularis & -2.12 & 1.14 & 1.63 \\
\hline & Contig5644 & Putative docking protein 5 (DOK5), DOK family & Ixodes scapularis & -1.60 & 1.27 & 1.44 \\
\hline & CV444871 & Putative cation-independent mannose-6-phosphate receptor (IGF2R), MRL1/IGF2R family & Tetraodon nigroviridis & -1.19 & 1.57 & 1.38 \\
\hline & CV447421 & Putative protein phosphatase PP2A $55 \mathrm{kDa}$ regulatory subunit (tws), Phosphatase $2 \mathrm{~A}$ regulatory subunit $\mathrm{B}$ family & Ixodes scapularis & -1.32 & 1.31 & 1.31 \\
\hline & Contig2486 & Putative SH3KBP1-binding protein 1 (SH3KBP1), KCTD3 family & Ixodes scapularis & -1.36 & 1.18 & 1.27 \\
\hline & Contig2490 & Putative TNF receptor-associated factor 6 (TRAF6), TNF receptor-associated factor family, A subfamily & Branchiostoma floridae & -1.24 & 1.15 & 1.19 \\
\hline & TC15335 & Putative Kelch-like protein 2 (KLHL2), Mayven & Ixodes scapularis & -1.08 & 1.24 & 1.16 \\
\hline & Contig2520 & Putative phosphatidylinositol 3-kinase regulatory subunit alpha (Pik3r1), PI3K p85 subunit family & Ixodes scapularis & -1.01 & 1.18 & 1.10 \\
\hline \multirow[t]{8}{*}{ Transcription } & CV457291 & Putative zinc finger protein, Krueppel $\mathrm{C} 2 \mathrm{H} 2$-type zinc-finger protein family & Ailuropoda melanoleuca & -4.10 & 2.27 & 3.18 \\
\hline & Contig3306 & Putative CCCH-type Zn-finger protein (ZFP36L1) & Ixodes scapularis & -3.30 & 1.87 & 2.58 \\
\hline & Contig 4738 & Putative zinc finger protein, Krueppel $\mathrm{C} 2 \mathrm{H} 2$-type zinc-finger protein family & Mus musculus & -2.90 & 2.05 & 2.47 \\
\hline & Contig3878 & Putative NFX1-type zinc finger-containing protein 1 & Acyrthosiphon pisum & -2.37 & 2.43 & 2.40 \\
\hline & CK173279 & Putative zinc finger protein, Krueppel $\mathrm{C} 2 \mathrm{H} 2$-type zinc-finger protein family & Equus caballus & -2.45 & 1.79 & 2.12 \\
\hline & CV455763 & Putative polycomb complex protein BMI-1(BMI1), С3HC4 type (RING finger) & $\begin{array}{l}\text { Xenopus (Silurana) } \\
\text { tropicalis }\end{array}$ & -2.41 & 1.78 & 2.09 \\
\hline & Contig6842 & Putative bromo adjacent homology domain-containing 1 protein (BAHD1) & Ixodes scapularis & -2.57 & 1.48 & 2.03 \\
\hline & Contig6925 & Putative RING finger protein 17 (Rnf17) & Ixodes scapularis & -2.00 & 1.78 & 1.89 \\
\hline
\end{tabular}




\begin{tabular}{|c|c|c|c|c|c|c|}
\hline \multirow[t]{2}{*}{$\begin{array}{l}\text { Transcript category } \\
\text { (KOG classification) }^{\text {a }}\end{array}$} & Contig $^{b}$ & Description $^{c}$ & Species $^{d}$ & $\begin{array}{c}\mathrm{MG} / \mathrm{O}^{f} \\
\log \mathrm{FC}^{e}\end{array}$ & $\begin{array}{l}\mathrm{O} / \mathrm{SG}^{9} \\
\operatorname{logFC}^{\mathrm{e}}\end{array}$ & $\begin{array}{l}\text { Avarege } \\
\text { logFC }\end{array}$ \\
\hline & TC16744 & Putative (histone-H3)-Iysine-36 demethylase (KDM2B), JHDM1 histone demethylase family & Gallus gallus & -2.40 & 1.37 & 1.88 \\
\hline \multirow[t]{22}{*}{ Transcription } & CK180492 & Putative tudor domain containing 1 protein (TDRD1), TDRD1 family & Ixodes scapularis & -2.12 & 1.58 & 1.85 \\
\hline & Contig7758 & Putative zinc finger protein, Krueppel C2H2-type zinc-finger protein family & Danio rerio & -2.22 & 1.48 & 1.85 \\
\hline & Contig5974 & Putative Tudor domain-containing protein 1 (tdrd1), TDRD1 family & Ixodes scapularis & -1.95 & 1.58 & 1.77 \\
\hline & Contig4371 & Putative zinc finger protein, Krueppel $\mathrm{C} 2 \mathrm{H} 2$-type zinc-finger protein family & Danio rerio & -1.98 & 1.38 & 1.68 \\
\hline & Contig8088 & Putative zinc finger protein, Krueppel $\mathrm{C} 2 \mathrm{H} 2$-type zinc-finger protein family & Branchiostoma floridae & -1.45 & 1.88 & 1.67 \\
\hline & CK173872 & Putative lethal(3)malignant brain tumor-like protein 2 (L3MBTL2) & Saccoglossus kowalevskii & -1.68 & 1.53 & 1.60 \\
\hline & CK184156 & Putative protein E3 SUMO-protein ligase PIAS (PIAS3), PIAS family & Ixodes scapularis & -1.81 & 1.35 & 1.58 \\
\hline & CV454199 & Putative zinc finger protein, Krueppel $\mathrm{C} 2 \mathrm{H} 2$-type zinc-finger protein family & Ixodes scapularis & -1.73 & 1.41 & 1.57 \\
\hline & CV443642 & Putative $\mathrm{C} 2 \mathrm{H}$-type $\mathrm{Zn}$-finger protein, Krueppel $\mathrm{C} 2 \mathrm{H}$ 2-type zinc-finger protein family & Ailuropoda melanoleuca & -1.91 & 1.20 & 1.56 \\
\hline & Contig4264 & Putative Tudor domain-containing protein 1 (tdrd1), TDRD1 family & Ixodes scapularis & -1.36 & 1.55 & 1.45 \\
\hline & Contig7985 & Putative zinc finger protein, Krueppel C2H2-type zinc-finger protein family & Ixodes scapularis & -1.35 & 1.51 & 1.43 \\
\hline & Contig1286 & Putative supporter of activation of yellow protein $(e(y) 3)$, SAYP family & Ixodes scapularis & -1.54 & 1.32 & 1.43 \\
\hline & Contig312 & Putative zinc finger protein, Krueppel C2H2-type zinc-finger protein family & Ixodes scapularis & -1.31 & 1.41 & 1.36 \\
\hline & Contig5889 & Putative transcription initiation factor TFIID subunit 11 (TAF11), TAF11 family & Ixodes scapularis & -1.64 & 1.04 & 1.34 \\
\hline & Contig2000 & Putative transcriptional repressor p66-beta (GATAD2B) & Ixodes scapularis & -1.41 & 1.19 & 1.30 \\
\hline & Contig268 & Putative CCR4-NOT transcription complex subunit 4 (CNOT4) & Homo sapiens & -1.42 & 1.17 & 1.29 \\
\hline & Contig5555 & Putative RNA uridylyltransferase (ZCCHC11) & Monodelphis domestica & -1.45 & 1.07 & 1.26 \\
\hline & CV453575 & Putative lymphoid-specific helicase (HELLS), SNF2/RAD54 helicase family & Ixodes scapularis & -1.43 & 1.09 & 1.26 \\
\hline & Contig4658 & Putative histone-arginine $\mathrm{N}$-methyltransferase (PRMT6), Protein arginine $\mathrm{N}$-methyltransferase family, PRMT6 subfamily & Ixodes scapularis & -1.14 & 1.27 & 1.21 \\
\hline & Contig2701 & Putative DNA-directed RNA polymerase III subunit RPC1 (POLR3A), RNA polymerase beta' chain family & Ixodes scapularis & -1.13 & 1.20 & 1.16 \\
\hline & CK175516 & Putative GA-binding protein subunit beta-2 (GABPB2) & Saccoglossus kowalevskii & -1.09 & 1.04 & 1.07 \\
\hline & Contig4680 & Putative RE1-silencing transcription factor (REST) & Ixodes scapularis & -2.56 & 2.19 & 2.38 \\
\hline \multirow{2}{*}{$\begin{array}{l}\text { Translation, ribosomal } \\
\text { structure and biogenesis }\end{array}$} & Contig1465 & Putative argonaute (AGO2), Eukaryotic translation initiation factor 2c 2, Argonaute family, Ago subfamily & Ixodes scapularis & -4.60 & 2.23 & 3.42 \\
\hline & Contig7471 & Putative argonaute (AGO4), Eukaryotic translation initiation factor 2c4, Argonaute family, Ago subfamily & Ixodes scapularis & -4.25 & 2.38 & 3.31 \\
\hline
\end{tabular}




\begin{tabular}{|c|c|c|c|c|c|c|}
\hline \multirow[t]{2}{*}{$\begin{array}{l}\text { Transcript category } \\
\text { (KOG classification) }^{\mathrm{a}}\end{array}$} & Contig $^{b}$ & Description $^{\mathrm{c}}$ & Species $^{d}$ & $\begin{array}{l}\mathrm{MG} / \mathrm{O}^{f} \\
\log \mathrm{FC} \\
\end{array}$ & $\begin{array}{l}\mathrm{O} / \mathrm{SG}^{g} \\
\log ^{\mathrm{F} \mathrm{C}^{\mathrm{e}}}\end{array}$ & $\begin{array}{l}\text { Avarege } \\
\text { logFC }\end{array}$ \\
\hline & Contig1423 & Putative protein LSM14 homolog A (LSM14A), LSM14 family & Ixodes scapularis & -3.95 & 2.67 & 3.31 \\
\hline \multirow{9}{*}{$\begin{array}{l}\text { Translation, ribosomal } \\
\text { structure and biogenesis }\end{array}$} & CK178055 & Putative argonaute (AGO4), Eukaryotic translation initiation factor 2c, Argonaute family, Ago subfamily & Schistosoma mansoni & -3.67 & 2.70 & 3.18 \\
\hline & Contig2465 & Putative argonaute (AGO1), Eukaryotic translation initiation factor 2c 1, Argonaute family, Ago subfamily & Ixodes scapularis & -2.27 & 1.85 & 2.06 \\
\hline & Contig154 & Putative argonaute (AGO2), Eukaryotic translation initiation factor $2 \mathrm{c} 2$, Argonaute family, Ago subfamily & Ixodes scapularis & -2.05 & 1.79 & 1.92 \\
\hline & CV451557 & Putative argonaute (AGO2), Eukaryotic translation initiation factor $2 \mathrm{c} 2$, Argonaute family, Ago subfamily & Ixodes scapularis & -1.35 & 1.38 & 1.37 \\
\hline & CV439653 & Putative polyadenylate-binding protein-interacting protein 1 (PAIP1) & Ixodes scapularis & -1.00 & 1.38 & 1.19 \\
\hline & Contig8368 & Putative B-box type zinc finger protein ncl-1 (ncl-1) & Ixodes scapularis & -3.04 & 1.51 & 2.28 \\
\hline & Contig1543 & Putative DNA-directed RNA polymerase III subunit RPC7 (POLR3G), Eukaryotic RPC7 RNA polymerase subunit family & Ixodes scapularis & -1.59 & 1.23 & 1.41 \\
\hline & Contig8120 & Putative U3 small nucleolar RNA-associated protein 15 homolog (UTP15) & Ixodes scapularis & -1.50 & 1.29 & 1.39 \\
\hline & CV455361 & Putative Integrator complex subunit 3 (INTS3), Integrator subunit 3 family & Ixodes scapularis & -1.02 & 1.27 & 1.14 \\
\hline
\end{tabular}

${ }^{\mathrm{b}}$ Assigned contiguous sequence identification for transcripts following assembly of all available expressed sequence tags and the R. microplus Gene Index version 2.1 .

${ }^{\mathrm{c}}$ The functional annotation of genes based on comparison of BLAST outputs from seven databases outlined in Section 2.4. All transcript descriptions are based on consensus with database entries from Uniprot (http://www.uniprot.org/uniprot/) and BRENDA (http://www.brenda-enzymes.org/), in the case of enzymes.

${ }^{\mathrm{d}}$ Species indicated that showed the highest sequence similarity to $R$. microplus sequences following non-redundant database (NR) BLAST analysis, independent of final assignment.

${ }^{e}$ Log $_{2}$ expression ratios (LogFC) calculated for group pair-wise comparison, to identify significant differentially expressed transcripts with $p$-values adjusted for multiple comparisons false discovery rates.

${ }^{\mathrm{f}} \mathrm{Log}_{2}$ expression for group pair-wise comparison between midgut (MG) and ovaries $(\mathrm{O})$. Values of MG/O $>1$ correspond to genes that are more expressed in midgut, whereas MG/O $<1$ correspond to genes that are more expressed in ovaries.

${ }^{9} \mathrm{Log}_{2}$ expression for group pair-wise comparison between ovaries $(\mathrm{O})$ and salivary glands (SG). Values of $\mathrm{O} / \mathrm{SG}>1$ correspond to genes that are more expressed in ovaries, whereas $\mathrm{O} / \mathrm{SG}<1$ correspond to genes that are more expressed in salivary glands.

${ }^{\mathrm{h}}$ Average $\mathrm{Log}_{2}$ expression obtained for up-regulated genes across all tissue comparisons. All negative values have been treated as positive for the calculation of the arithmetic mean, in order to obtain an overall change in expression for each gene. 
Supplementary Table S2. Shared transcripts expressed in all tissues of feeding Rhipicephalus microplus female ticks identified from microarray analysis. Transcripts were chosen using an $M$ value $>0$ and a minimum intensity threshold of 1,000 .

\begin{tabular}{|c|c|c|c|c|c|}
\hline $\begin{array}{l}\text { Transcript category } \\
\text { (KOG classification) }^{\mathrm{a}}\end{array}$ & Contig $^{b}$ & Description $^{\mathrm{C}}$ & Species $^{d}$ & $\begin{array}{l}\text { Intensity } \\
\text { threshold } \\
>1,000^{\mathrm{e}}\end{array}$ & $\begin{array}{l}\text { Intensity } \\
\text { threshold } \\
>2,000^{\dagger}\end{array}$ \\
\hline \multirow{10}{*}{$\begin{array}{l}\text { Amino acid transport and } \\
\text { metabolism }\end{array}$} & Contig387 & Putative phosphoglycerate dehydrogenase (Phgdh), D-isomer specific 2-hydroxyacid dehydrogenase family & Ixodes scapularis & Yes & Yes \\
\hline & Contig8440 & Putative phosphoglycerate dehydrogenase (Phgdh), D-isomer specific 2-hydroxyacid dehydrogenase family & Ixodes scapularis & Yes & Yes \\
\hline & Contig2665 & Putative nitrilase and fragile histidine triad fusion protein NitFhit (NitFhit), UPF0012 family & Ixodes scapularis & Yes & No \\
\hline & Contig632 & Putative acireductone synthase, Enolase-phosphatase E1 (enoph1), HAD-like hydrolase superfamily, MasA/MtnC family & $\begin{array}{l}\text { Xenopus (Silurana) } \\
\text { tropicalis }\end{array}$ & Yes & No \\
\hline & Contig4269 & Putative fumarylacetoacetase (FAH), FAH family & Ixodes scapularis & Yes & No \\
\hline & CV451089 & Putative carboxypeptidase $\mathrm{Q}(\mathrm{CPQ})$, Peptidase M28 family & Ixodes scapularis & Yes & No \\
\hline & Contig8749 & Putative serine hydrolase-like protein 2 (SERHL2), AB hydrolase superfamily & Ixodes scapularis & Yes & No \\
\hline & Contig6115 & Putative cytosol alanyl aminopeptidase, puromycin-sensitive aminopeptidase (NPEPPS), Peptidase M1 family & $\begin{array}{l}\text { Pediculus humanus } \\
\text { corporis }\end{array}$ & Yes & No \\
\hline & Contig4651 & Putative pyrroline-5-carboxylate reductase, mitochondrial (PYCR1), Pyrroline-5-carboxylate reductase family & Ixodes scapularis & Yes & No \\
\hline & Contig3977 & Putative peptidase M20 domain-containing protein (PM20D2), Peptidase M20A family & Trichoplax adhaerens & Yes & No \\
\hline \multirow[t]{9}{*}{$\begin{array}{l}\text { Carbohydrate transport } \\
\text { and metabolism }\end{array}$} & Contig4405 & Putative GDP-L-fucose synthase (Tsta3), Fucose synthase family & $\begin{array}{l}\text { Xenopus (Silurana) } \\
\text { tropicalis }\end{array}$ & Yes & Yes \\
\hline & Contig497 & Putative GDP-mannose 4,6 dehydratase (GMDS), GDP-mannose 4,6-dehydratase family & Ornithorhynchus anatinus & Yes & Yes \\
\hline & Contig835 & Putative glucan 1,3-alpha-glucosidase (GANAB), Glycosyl hydrolase 31 family & Dermacentor variabilis & Yes & Yes \\
\hline & Contig8022 & Putative tau-protein kinase (GSK3A), Protein kinase superfamily, CMGC Ser/Thr protein kinase family, GSK-3 subfamily & Ixodes scapularis & Yes & Yes \\
\hline & CV435786 & Putative GDP-fucose transporter 1 (Slc35c1), TPT transporter family, SLC35C subfamily & Ixodes scapularis & Yes & No \\
\hline & Contig2505 & Putative glycolipid transfer protein (GLTP), GLTP family & Ixodes scapularis & Yes & No \\
\hline & Contig1250 & Putative lactoylglutathione lyase (GLO1), Glyoxalase I family & Rattus norvegicus & Yes & No \\
\hline & Contig7070 & Putative malonyl-CoA decarboxylase (MLYCD) & Branchiostoma floridae & Yes & No \\
\hline & Contig5138 & Putative Monocarboxylate transporter 3 (SLC16A8), Major facilitator superfamily, Monocarboxylate porter family & Ixodes scapularis & Yes & No \\
\hline
\end{tabular}




\begin{tabular}{|c|c|c|c|c|c|}
\hline $\begin{array}{l}\text { Transcript category } \\
{\text { (KOG classification })^{\text {a }}}\end{array}$ & Contig $^{b}$ & Description $^{c}$ & Species $^{d}$ & $\begin{array}{c}\text { Intensity } \\
\text { threshold } \\
>1,000^{\mathrm{e}}\end{array}$ & $\begin{array}{l}\text { Intensity } \\
\text { threshold } \\
>2,000^{\dagger}\end{array}$ \\
\hline \multirow{3}{*}{$\begin{array}{l}\text { Carbohydrate transport } \\
\text { and metabolism }\end{array}$} & Contig7956 & Putative chitinase domain-containing protein 1 (CHID1), Glycosyl hydrolase 18 family & Taeniopygia guttata & Yes & No \\
\hline & Contig3590 & Putative glucose-6-phosphate 1-epimerase, Glucose-6-phosphate 1-epimerase family & Nasonia vitripennis & Yes & No \\
\hline & Contig5221 & Putative UDP-sugar diphosphatase (NUDT14), Nudix hydrolase family & Tribolium castaneum & Yes & No \\
\hline \multicolumn{6}{|l|}{ Cell cycle control, cell } \\
\hline \multirow{10}{*}{$\begin{array}{l}\text { division, chromosome } \\
\text { partitioning }\end{array}$} & Contig4133 & Putative baculoviral IAP repeat-containing protein 5 (BIRC5), Survivin, IAP family & Ixodes scapularis & Yes & No \\
\hline & Contig8318 & Putative cyclin-dependent kinase 7 (CDK7), Protein kinase superfamily, CMGC Ser/Thr protein kinase family, CDC2/CDKX subfamily & Ixodes scapularis & Yes & No \\
\hline & Contig2869 & Putative cell cycle control protein 50A (TMEM30A), CDC50/LEM3 family & Ixodes scapularis & Yes & No \\
\hline & Contig8432 & Putative non-specific protein-tyrosine kinase (WEE1), Protein kinase superfamily, Ser/Thr protein kinase family, WEE1 subfamily & Platynereis dumerilii & Yes & No \\
\hline & Contig3399 & Putative malignant T-cell-amplified sequence 1 (MCTS1), MCTS1 family & $\begin{array}{l}\text { Pediculus humanus } \\
\text { corporis }\end{array}$ & Yes & No \\
\hline & EW679736.1 & Putative ubiquitin-like protein Nedd8 (NEDD8), Ubiquitin family & Amblyomma americanum & Yes & No \\
\hline & Contig2832 & Putative regulator of chromosome condensation (RCC1) & Ixodes scapularis & Yes & No \\
\hline & Contig6A & Putative cyclin-dependent kinase (CDK10), Protein kinase superfamily, CMGC Ser/Thr protein kinase family, CDC2/CDKX subfamily & Ixodes scapularis & Yes & No \\
\hline & Contig3338 & Putative septin-1 (SEP1), Septin family & Ixodes scapularis & Yes & No \\
\hline & Contig1039 & Putative protein MIS12 homolog (MIS12), Mis12 family & Taeniopygia guttata & Yes & No \\
\hline Cell motility & Contig2605 & Putative dynein light chain Tctex-type 1 (Dynlt1) & Ixodes scapularis & Yes & No \\
\hline \multirow[t]{3}{*}{$\begin{array}{l}\text { Cell wall/ membrane/ } \\
\text { envelope biogenesis }\end{array}$} & CV447425 & Putative dynamin-like $120 \mathrm{kDa}$ protein, mitochondrial (OPA1), Dynamin family & Ixodes scapularis & Yes & No \\
\hline & Contig5042 & Putative coiled-coil-helix-coiled-coil-helix domain-containing protein 3 (CHCHD3) & Ixodes scapularis & Yes & No \\
\hline & Contig527 & Putative NSFL1 cofactor p47 (NSFL1C), NSFL1C family & Ixodes scapularis & Yes & No \\
\hline \multirow{2}{*}{$\begin{array}{l}\text { Chromatin structure and } \\
\text { dynamics }\end{array}$} & Contig1194 & Putative nucleosome assembly protein 1 -like 1 (nap111-b) & Ixodes scapularis & Yes & Yes \\
\hline & Contig1337 & Putative Inhibitor of growth protein 2 (ING2), ING family & Ixodes scapularis & Yes & No \\
\hline
\end{tabular}




\begin{tabular}{|c|c|c|c|c|c|}
\hline $\begin{array}{l}\text { Transcript category } \\
\left(\text { KOG classification) }{ }^{a}\right.\end{array}$ & Contig $^{\mathrm{b}}$ & Description $^{\circ}$ & Species $^{\mathrm{d}}$ & $\begin{array}{c}\text { Intensity } \\
\text { threshold } \\
>1,000^{\mathrm{e}}\end{array}$ & $\begin{array}{c}\text { Intensity } \\
\text { threshold } \\
>2,000^{\dagger}\end{array}$ \\
\hline \multirow{2}{*}{$\begin{array}{l}\text { Chromatin structure and } \\
\text { dynamics }\end{array}$} & Contig3136 & Putative something about silencing protein 10 (UTP3), SAS10 family & Ixodes scapularis & Yes & No \\
\hline & Contig6878 & Putative male-specific lethal 3 homolog (MSL3) & Callithrix jacchus & Yes & No \\
\hline \multirow{3}{*}{$\begin{array}{l}\text { Coenzyme transport and } \\
\text { metabolism }\end{array}$} & CV456939 & Putative protoheme IX farnesyltransferase, mitochondrial (COX10), UbiA prenyltransferase family & Ixodes scapularis & Yes & No \\
\hline & CK174330 & Putative ubiquinone biosynthesis monooxygenase $\mathrm{COQ} 6$ (COQ6), UbiH/COQ6 family & Hydra magnipapillata & Yes & No \\
\hline & Contig2881 & Putative 4-hydroxybenzoate polyprenyltransferase, mitochondrial (coq2), UbiA prenyltransferase family & $\begin{array}{l}\text { Anopheles gambiae str. } \\
\text { PEST }\end{array}$ & Yes & No \\
\hline \multirow[t]{13}{*}{ Cytoskeleton } & Contig3106 & Putative myosin-2 essential light chain (Mlc-c) & Ixodes scapularis & Yes & Yes \\
\hline & Contig3933 & Putative myosin regulatory light chain, Protein spaghetti-squash (sqh) & Ixodes pacificus & Yes & Yes \\
\hline & CK173010 & Putative Moesin/ezrin/radixin homolog 1 (MOE) & $\begin{array}{l}\text { Glossina morsitans } \\
\text { morsitans }\end{array}$ & Yes & Yes \\
\hline & Contig7803 & Putative beta-centractin (ACTR1B), Actin family, ARP1 subfamily & Ixodes scapularis & Yes & Yes \\
\hline & Contig1435 & Putative actin-related protein 3B (ACTR3B), Actin family, ARP3 subfamily & Bos taurus & Yes & Yes \\
\hline & Contig3798 & Putative actin-related protein Arp2/3 complex (ARPC4), ARPC4 family & $\begin{array}{l}\text { Pediculus humanus } \\
\text { corporis }\end{array}$ & Yes & Yes \\
\hline & Contig3260 & Putative dynein light chain type 2 (DYNLL2), Dynein light chain family & Ailuropoda melanoleuca & Yes & Yes \\
\hline & CV445272 & Putative actin-related protein 10 (ACTR10), Actin family & Monodelphis domestica & Yes & No \\
\hline & CV439239 & Putative actin-related protein 5 (ACTR5), Actin family, ARP5 subfamily & Saccoglossus kowalevskii & Yes & No \\
\hline & Contig5192 & Putative actin-related protein Arp2/3 complex (ARPC5), ARPC5 family & Ixodes scapularis & Yes & No \\
\hline & Contig613 & Putative Bridging integrator 3 (BIN3) & Ixodes scapularis & Yes & No \\
\hline & Contig582 & Putative Calponin 3 (CNN3), Calponin family & Ixodes scapularis & Yes & No \\
\hline & Contig1979 & Putative nuclear distribution protein nudE-like 1 (NDEL1), NudE family & Saccoglossus kowalevskii & Yes & No \\
\hline \multirow[t]{3}{*}{ Defense mechanisms } & Contig3зз9 & Putative Bax inhibitor 1 (TMBIM6), Bl1 family & Ixodes scapularis & Yes & Yes \\
\hline & Contig3075 & Putative Complement component $1 \mathrm{Q}$ subcomponent-binding protein, mitochondrial (C1QBP), MAM33 family & Ixodes scapularis & Yes & No \\
\hline & Contig113 & Putative S-formylglutathione hydrolase (ESD), Putative Esterase D, esterase D family & Ixodes scapularis & Yes & No \\
\hline
\end{tabular}




\begin{tabular}{|c|c|c|c|c|c|}
\hline $\begin{array}{l}\text { Transcript category } \\
\text { (KOG classification) }^{\mathrm{a}}\end{array}$ & Contig $^{b}$ & Description $^{\mathrm{C}}$ & Species $^{d}$ & $\begin{array}{l}\text { Intensity } \\
\text { threshold } \\
>1,000^{\mathrm{e}}\end{array}$ & 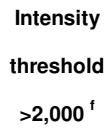 \\
\hline \multirow{12}{*}{$\begin{array}{l}\text { Defense mechanisms } \\
\text { Energy production and } \\
\text { conversion }\end{array}$} & Contig2904 & Putative S-formylglutathione hydrolase (ESD), Putative Esterase D, esterase D family & Ixodes scapularis & Yes & No \\
\hline & Contig2837 & Putative cytochrome c oxidase, subunit 1 (MT-CO1), Heme-copper respiratory oxidase family & Rhipicephalus sanguineus & Yes & Yes \\
\hline & Contig4422 & Putative $\operatorname{NAD}(\mathrm{P})(+)$ transhydrogenase (AB-specific), mitochondrial (NNT), AlaDH/PNT family, PNT beta subunit family & Ixodes scapularis & Yes & Yes \\
\hline & Contig4681 & Putative ADP/ATP translocase 2 (SLC25A5), Mitochondrial carrier family & Ixodes scapularis & Yes & Yes \\
\hline & Contig424 & Putative isocitrate dehydrogenase $(\mathrm{NADP}(+))$, mitochondrial (IDH2), Isocitrate and isopropylmalate dehydrogenases family & Ixodes scapularis & Yes & Yes \\
\hline & Contig8631 & Putative V-type proton ATPase subunit $\mathrm{H}$ (VhaSFD), V-ATPase $\mathrm{H}$ subunit family & Nasonia vitripennis & Yes & Yes \\
\hline & Contig2278 & Putative V-type proton ATPase subunit e 1 (ATPGVOE1), V-ATPase e subunit family & Ixodes scapularis & Yes & Yes \\
\hline & Contig8181 & Putative V-type proton ATPase subunit G (Vha13), V-ATPase G subunit family & Ixodes scapularis & Yes & Yes \\
\hline & Contig596 & Putative pyruvate dehydrogenase protein $\mathrm{X}$ component, mitochondrial (PdhX), 2-oxoacid dehydrogenase family & Ixodes scapularis & Yes & No \\
\hline & Contig1552 & Putative $\mathrm{H}(+)$-transporting two-sector ATPase, mitochondrial (beta subunit) (ATP5B), ATPase alpha/beta chains family & Ixodes scapularis & Yes & No \\
\hline & Contig7051 & Putative V-type proton ATPase $116 \mathrm{kDa}$ subunit a isoform 1 (ATP6VOA1), V-ATPase $116 \mathrm{kDa}$ subunit family & Ixodes scapularis & Yes & No \\
\hline & Contig91 & Putative V-type proton ATPase subunit C 1 (ATP6V1C1), V-ATPase C subunit family & Amblyomma americanum & Yes & No \\
\hline \multirow{3}{*}{$\begin{array}{l}\text { Inorganic ion transport } \\
\text { and metabolism }\end{array}$} & CV447239 & Putative sodium-independent sulfate anion transporter (Slc26a11), SLC26A/SulP transporter family & Ixodes scapularis & Yes & Yes \\
\hline & Contig3592 & Putative sodium/potassium-transporting ATPase subunit beta-2 (nrv2), $X(+) /$ potassium ATPases subunit beta family & Ixodes scapularis & Yes & No \\
\hline & Contig2982 & Putative cation-transporting ATPase 13A1 (ATP13A1), Cation transport ATPase (P-type) family, Type V subfamily & Ixodes scapularis & Yes & No \\
\hline \multirow{3}{*}{$\begin{array}{l}\text { Inorganic ion transport } \\
\text { and metabolism }\end{array}$} & CV454271 & Putative cation-transporting ATPase 13A1 (ATP13A1), Cation transport ATPase (P-type) family, Type V subfamily & Tribolium castaneum & Yes & No \\
\hline & Contig3147 & Putative Store-operated calcium entry-associated regulatory factor (tmem66), SARAF family & Monodelphis domestica & Yes & No \\
\hline & Contig17 & Putative Store-operated calcium entry-associated regulatory factor (tmem66), SARAF family & Ixodes scapularis & Yes & No \\
\hline \multirow[t]{3}{*}{$\begin{array}{l}\text { Intracellular trafficking, } \\
\text { secretion, and vesicular } \\
\text { transport }\end{array}$} & Contig6255 & Putative mitochondrial import inner membrane translocase subunit TIM13 (TIM13), Small Tim family & $\begin{array}{l}\text { Pediculus humanus } \\
\text { corporis }\end{array}$ & Yes & Yes \\
\hline & Contig3747 & Putative nuclear transport factor 2 (NUTF2) & Aedes aegypti & Yes & Yes \\
\hline & Contig4224 & Putative signal recognition particle $14 \mathrm{kDa}$ protein (SRP14), SRP14 family & Rhipicephalus sanguineus & Yes & Yes \\
\hline
\end{tabular}




\begin{tabular}{|c|c|c|c|c|c|}
\hline $\begin{array}{l}\text { Transcript category } \\
\text { (KOG classification) }^{\mathrm{a}}\end{array}$ & Contig $^{b}$ & Description $^{\mathrm{C}}$ & Species $^{d}$ & $\begin{array}{l}\text { Intensity } \\
\text { threshold } \\
>1,000^{\mathrm{e}}\end{array}$ & $\begin{array}{c}\text { Intensity } \\
\text { threshold } \\
>2,000^{\dagger}\end{array}$ \\
\hline \multicolumn{6}{|l|}{ Intracellular trafficking, } \\
\hline & Contig7685 & Putative vacuolar protein-sorting-associated protein 36 (VPS36), VPS36 family & Ixodes scapularis & Yes & Yes \\
\hline & CV442636 & Putative coatomer subunit alpha (COPA) & Ixodes scapularis & Yes & Yes \\
\hline & TC17848 & Putative coatomer subunit gamma-2 (COPG2), COPG family & Ixodes scapularis & Yes & Yes \\
\hline & Contig679 & Putative golgi reassembly-stacking protein 2 (GORASP2), GORASP family & Branchiostoma floridae & Yes & Yes \\
\hline & Contig8588 & Putative ADP-ribosylation factor 1 (Arf79F), Small GTPase superfamily, Arf family & Argas monolakensis & Yes & Yes \\
\hline & Contig3642 & Putative ADP-ribosylation factor 5 (ARF5), Small GTPase superfamily, Arf family & Marsupenaeus japonicus & Yes & Yes \\
\hline & CV443072 & Putative mannose lectin ERGIC-53 (LMAN1) & Ixodes scapularis & Yes & Yes \\
\hline & Contig1803 & Putative peroxisomal membrane protein 11C (PEX11G), Peroxin-11 family & Oryctolagus cuniculus & Yes & No \\
\hline & CK181968 & Putative Mitochondrial Rho GTPase 1 (RHOT1), Mitochondrial Rho GTPase family & Ixodes scapularis & Yes & No \\
\hline & Contig966 & Putative charged multivesicular body protein 5 (CHMP5), SNF7 family & Ixodes scapularis & Yes & No \\
\hline & Contig2591 & Putative protein YIPF5 (yipf5), YIP1 family & Ixodes scapularis & Yes & No \\
\hline & Contig591 & Putative GRIP and coiled-coil domain-containing protein 2 (GCC2) & Macaca mulatta & Yes & No \\
\hline & Contig5586 & Putative Syntaxin-5 (STX5), syntaxin family & Saccoglossus kowalevskii & Yes & No \\
\hline & Contig4969 & Putative Mitochondrial import receptor subunit TOM22 homolog (TOMM22), Tom22 family & Tribolium castaneum & Yes & No \\
\hline & CK189108 & Putative mitochondrial import receptor subunit TOM40 homolog (TOMM40), Tom40 family & $\begin{array}{l}\text { Anopheles gambiae str. } \\
\text { PEST }\end{array}$ & Yes & No \\
\hline & Contig1350 & Putative trafficking protein particle complex subunit 3 (TRAPPC3), TRAPP small subunits family, BET3 subfamily & Ixodes scapularis & Yes & No \\
\hline & Contig4688 & Putative protein kish-A (TMEM167A), KISH family & Argas monolakensis & Yes & No \\
\hline & Contig6912 & Putative charged multivesicular body protein 1a (CHMP1A), SNF7 family & Ixodes scapularis & Yes & No \\
\hline & Contig7572 & Putative coatomer subunit beta (COPB1) & $\begin{array}{l}\text { Xenopus (Silurana) } \\
\text { tropicalis }\end{array}$ & Yes & No \\
\hline & Contig6131 & Putative protein transport protein Sec24A (SEC24A), SEC23/SEC24 family, SEC24 subfamily & Ixodes scapularis & Yes & No \\
\hline & Contig6855 & Putative AP-1 complex subunit mu-1 (AP1M1), Adaptor complexes medium subunit family & Tribolium castaneum & Yes & No \\
\hline
\end{tabular}




\begin{tabular}{|c|c|c|c|c|c|}
\hline $\begin{array}{l}\text { Transcript category } \\
\text { (KOG classification) }^{\text {a }}\end{array}$ & Contig $^{b}$ & Description $^{\mathrm{C}}$ & Species $^{d}$ & $\begin{array}{l}\text { Intensity } \\
\text { threshold } \\
>1,000^{\mathrm{e}}\end{array}$ & $\begin{array}{l}\text { Intensity } \\
\text { threshold } \\
>2,000^{\dagger}\end{array}$ \\
\hline \multirow[t]{9}{*}{$\begin{array}{l}\text { Intracellular trafficking, } \\
\text { secretion, and vesicular } \\
\text { transport }\end{array}$} & Contig3246 & Putative protein cornichon homolog (cni), Cornichon family & $\begin{array}{l}\text { Strongylocentrotus } \\
\text { purpuratus }\end{array}$ & Yes & No \\
\hline & Contig6268 & Putative Ras-related protein Rab-6A (RAB6A), Small GTPase superfamily, Rab family & Ixodes scapularis & Yes & No \\
\hline & Contig6711 & Putative Importin subunit alpha-6 (KPNA5), Importin alpha family & Ixodes scapularis & Yes & No \\
\hline & CV439557 & Putative lipopolysaccharide-responsive and beige-like anchor protein (LRBA) & Ixodes scapularis & Yes & No \\
\hline & Contig101 & Putative protein ERGIC-53 (LMAN1) & Ixodes scapularis & Yes & No \\
\hline & Contig201A & Putative phosphoserine phosphatase, Vacuolar protein sorting-associated protein 29 (VPS29), VPS29 family & Ixodes scapularis & Yes & No \\
\hline & Contig8136 & Putative E3 SUMO-protein ligase RanBP2 (RANBP2) & Ixodes scapularis & Yes & No \\
\hline & Contig2281 & Putative mitochondrial import receptor subunit TOM7 (TOM7), Tom7 family & Apis mellifera & Yes & No \\
\hline & CK185391 & Putative exocyst complex component 7 (Exoc7), EXO70 family & Ixodes scapularis & Yes & No \\
\hline \multirow{14}{*}{$\begin{array}{l}\text { Lipid transport and } \\
\text { metabolism }\end{array}$} & Contig1246 & Putative 3-hydroxyacyl-CoA dehydrogenase (HADH), 3-hydroxyacyl-CoA dehydrogenase family & Ixodes scapularis & Yes & Yes \\
\hline & Contig8253 & Putative Acetyl-CoA C-acetyltransferase (ACAT1), mitochondrial, Thiolase family & Ixodes scapularis & Yes & Yes \\
\hline & Contig2916 & Putative Acetyl-CoA C-acetyltransferase (ACAT1), mitochondrial, Thiolase family & Ixodes scapularis & Yes & Yes \\
\hline & Contig6086 & Putative methylmalonyl-CoA epimerase, mitochondrial (MCEE), Glyoxalase I family & Ixodes scapularis & Yes & No \\
\hline & Contig1953 & Putative acetyl-coenzyme A transporter 1 (sIc33a1), SLC33A transporter family & Ixodes scapularis & Yes & No \\
\hline & Contig3679 & Putative long-chain-fatty-acid--CoA ligase (ACSL), ATP-dependent AMP-binding enzyme family & Ixodes scapularis & Yes & No \\
\hline & Contig416 & Putative fatty-acid synthase (FASN) & Ixodes scapularis & Yes & No \\
\hline & Contig7867 & Putative Delta(3,5)-Delta(2,4)-dienoyl-CoA isomerase, mitochondrial (Ech1), Enoyl-CoA hydratase/isomerase family & Ixodes scapularis & Yes & No \\
\hline & Contig2062 & Putative fatty acid-binding protein (FABP3), Lipocalin, Calycin superfamily, Fatty-acid binding protein (FABP) family & Ixodes scapularis & Yes & No \\
\hline & CV436734 & Putative (acyl-carrier-protein) S-malonyltransferase, mitochondrial (MCAT), Type II malonyltransferase family & Ixodes scapularis & Yes & No \\
\hline & Contig4098 & Putative butyryl-CoA dehydrogenase (ACADS), Acyl-CoA dehydrogenase family & Ixodes scapularis & Yes & No \\
\hline & Contig1172 & Putative mitochondrial carnitine/acylcarnitine carrier protein (SLC25A20), mitochondrial carrier family & Ixodes scapularis & Yes & No \\
\hline & TC22535 & Putative phosphatidylinositol N-acetylglucosaminyltransferase (PIGP), PIGP family & Ixodes scapularis & Yes & No \\
\hline & Contig2902 & Putative phosphatidylinositide phosphatase SAC1 (SACM1L) & Ixodes scapularis & Yes & No \\
\hline
\end{tabular}




\begin{tabular}{|c|c|c|c|c|c|}
\hline $\begin{array}{l}\text { Transcript category } \\
\left(\text { KOG classification) }{ }^{a}\right.\end{array}$ & Contig ${ }^{b}$ & Description $^{\circ}$ & Species $^{\mathrm{d}}$ & $\begin{array}{c}\text { Intensity } \\
\text { threshold } \\
>1,000^{\mathrm{e}}\end{array}$ & $\begin{array}{c}\text { Intensity } \\
\text { threshold } \\
>2,000^{\dagger}\end{array}$ \\
\hline \multirow[t]{3}{*}{$\begin{array}{l}\text { Lipid transport and } \\
\text { metabolism }\end{array}$} & CV441576 & Putative protein spinster homolog 1 (SPNS1), Major facilitator superfamily, Spinster family & Tribolium castaneum & Yes & No \\
\hline & Contig167 & Putative Niemann-Pick type $\mathrm{C} 1$ domain-containing protein (NPC1), Patched family & Ixodes scapularis & Yes & No \\
\hline & Contig3515 & Putative glycerone-phosphate O-acyltransferase (GNPAT), GPAT/DAPAT family & $\begin{array}{l}\text { Strongylocentrotus } \\
\text { purpuratus }\end{array}$ & Yes & No \\
\hline \multirow[t]{2}{*}{ Nuclear structure } & CV439363 & Putative nucleoporin NUP53 (NUP35), Nup53 family & Ixodes scapularis & Yes & No \\
\hline & TC15380 & Putative nuclear pore complex protein Nup155 (NUP155), Non-repetitive/WGA-negative nucleoporin family & Ixodes scapularis & Yes & No \\
\hline \multirow[t]{3}{*}{ Nucleotide transport and } & Contig8942 & Putative dUTP diphosphatase (DUT), DUTPase family & Ixodes scapularis & Yes & Yes \\
\hline & Contig3765 & Putative cytidine deaminase (CDA), Cytidine and deoxycytidylate deaminase family & Ixodes scapularis & Yes & No \\
\hline & Contig6308 & Putative Nucleoside-triphosphatase, Cancer-related nucleoside-triphosphatase (NTPCR), THEP1 NTPase family & Ixodes scapularis & Yes & No \\
\hline \multirow{13}{*}{$\begin{array}{l}\text { Posttranslational } \\
\text { modification, protein } \\
\text { turnover, chaperones }\end{array}$} & Contig5499 & Putative heat shock protein 60 , mitochondrial (HSP60/HSPD1), Chaperonin (HSP60) family & $\begin{array}{l}\text { Hyalomma marginatum } \\
\text { rufipes }\end{array}$ & Yes & Yes \\
\hline & Contig5025 & Putative Stress-induced-phosphoprotein 1 (STIP1) & Harpegnathos saltator & Yes & Yes \\
\hline & Contig2747 & Putative endoplasmic reticulum resident protein 29 (ERP29) & Rhipicephalus sanguineus & Yes & Yes \\
\hline & Contig5214 & Putative RING-box protein $1 \mathrm{~A}$ (Roc1a), RING-box family & Ixodes scapularis & Yes & Yes \\
\hline & Contig1836 & Putative $15 \mathrm{kDa}$ selenoprotein (SEP15), Selenoprotein M/SEP15 family & Ixodes scapularis & Yes & Yes \\
\hline & Contig8175 & Putative ubiquitin-protein ligase (UbcD4), Ubiquitin-conjugating enzyme family & Ixodes scapularis & Yes & Yes \\
\hline & Contig2948 & Putative proteasome endopeptidase complex, subunit alpha type-2 (PSMA2), peptidase T1A family & Aedes aegypti & Yes & Yes \\
\hline & Contig903 & Putative Proteasome endopeptidase complex, subunit alpha type-7 (PSMA7), Peptidase T1A family & Ixodes scapularis & Yes & Yes \\
\hline & Contig887 & Putative proteasome endopeptidase complex, subunit beta type-1 (PROS26), peptidase T1B family & Tribolium castaneum & Yes & Yes \\
\hline & Contig2750 & Putative alpha-crystallin B chain (CRYAB), Small heat shock protein (HSP20) family & Dermacentor variabilis & Yes & Yes \\
\hline & Contig2634 & Putative heat shock protein beta-2 (HSPB2), Small heat shock protein (HSP20) family & Dermacentor variabilis & Yes & Yes \\
\hline & Contig1372 & Putative calnexin (CANX), Calreticulin family & Ixodes scapularis & Yes & Yes \\
\hline & Contig390 & Putative calreticulin (CALR), Calreticulin family & Rhipicephalus microplus & Yes & Yes \\
\hline
\end{tabular}




\begin{tabular}{|c|c|c|c|c|c|}
\hline $\begin{array}{l}\text { Transcript category } \\
\text { (KOG classification) }^{\mathrm{a}}\end{array}$ & Contig $^{b}$ & Description $^{c}$ & Species $^{d}$ & $\begin{array}{c}\text { Intensity } \\
\text { threshold } \\
>1,000^{\mathrm{e}}\end{array}$ & $\begin{array}{l}\text { Intensity } \\
\text { threshold } \\
>2,000^{\circ}\end{array}$ \\
\hline \multirow{24}{*}{$\begin{array}{l}\text { Posttranslational } \\
\text { modification, protein } \\
\text { turnover, chaperones }\end{array}$} & Contig210 & Putative T-complex protein 1 subunit alpha (TCP1), TCP-1 chaperonin family & Apis mellifera & Yes & Yes \\
\hline & Contig2441 & Putative T-complex protein 1 subunit epsilon (CCT5), TCP-1 chaperonin family & Ixodes scapularis & Yes & Yes \\
\hline & Contig2805 & Putative T-complex protein 1 subunit gamma (ССT3), TCP-1 chaperonin family & Ixodes scapularis & Yes & Yes \\
\hline & Contig790 & Putative T-complex protein 1 subunit theta (CCT8), TCP-1 chaperonin family & Ixodes scapularis & Yes & Yes \\
\hline & Contig9031 & Putative peptidylprolyl isomerase (CYP1), Cyclophilin-type PPlase family, PPlase A subfamily & Ixodes scapularis & Yes & Yes \\
\hline & Contig7969 & Putative Glutaredoxin-related protein 5, mitochondrial (GIrx5), Glutaredoxin family, Monothiol subfamily & Ixodes scapularis & Yes & Yes \\
\hline & Contig8311 & Putative lipoyltransferase 1, mitochondrial (LIPT1), LplA family & Ixodes scapularis & Yes & No \\
\hline & CV436024 & Putative ubiquitinyl hydrolase 1 (ATXN3), Ataxin-3 & Ixodes scapularis & Yes & No \\
\hline & Contig222A & Putative translocation protein SEC63 homolog (SEC63) & Ixodes scapularis & Yes & No \\
\hline & Contig5188 & Putative mitochondrial import inner membrane translocase subunit TIM14 (DNAJC19) & Ixodes scapularis & Yes & No \\
\hline & Contig155 & Putative DnaJ homolog subfamily C member 30 (DNAJC30) & Ixodes scapularis & Yes & No \\
\hline & Contig4436 & Putative prefoldin subunit 2 (PFDN2), Prefoldin subunit beta family & Ixodes scapularis & Yes & No \\
\hline & Contig5520 & Putative prefoldin subunit 5 (PFDN5), Prefoldin subunit alpha family & Ixodes scapularis & Yes & No \\
\hline & Contig7780 & Putative Stress-induced-phosphoprotein 1 (STIP1) & Ixodes scapularis & Yes & No \\
\hline & Contig4501 & Putative peptidylprolyl isomerase (PIN1) & Ixodes scapularis & Yes & No \\
\hline & Contig5483 & Putative Derlin-2 (DERL2), Derlin family & Ixodes scapularis & Yes & No \\
\hline & Contig1808 & Putative DnaJ homolog subfamily C member 8 (Dnajc8) & Ixodes scapularis & Yes & No \\
\hline & Contig2583 & Putative UBX domain-containing protein 6 (UBXN6) & Ixodes scapularis & Yes & No \\
\hline & CV446781 & Putative E3 ubiquitin-protein ligase UBR5 (UBR5) & Ixodes scapularis & Yes & No \\
\hline & Contig2212 & Putative Protein I(2)37Cc (I(2)37Cc), Prohibitin, Prohibitin family & Ixodes scapularis & Yes & No \\
\hline & CV440002 & Putative protein geranylgeranyltransferase type I, subunit beta (PGGT1B), Protein prenyltransferase subunit beta family & Ixodes scapularis & Yes & No \\
\hline & Contig441 & Putative S-phase kinase-associated protein 1 (skp1), SKP1 family & Ixodes scapularis & Yes & No \\
\hline & Contig4781 & Putative peptidylprolyl isomerase (PPIL3), Cyclophilin-type PPlase family. PPIL3 subfamily & Ovis aries & Yes & No \\
\hline & CK177789 & Putative thioredoxin-disulfide reductase (TXNRD3), Class-I pyridine nucleotide-disulfide oxidoreductase family & Branchiostoma floridae & Yes & No \\
\hline
\end{tabular}




\begin{tabular}{|c|c|c|c|c|c|}
\hline $\begin{array}{l}\text { Transcript category } \\
\text { (KOG classification) }^{\mathrm{a}}\end{array}$ & Contig $^{b}$ & Description $^{\mathrm{C}}$ & Species $^{d}$ & $\begin{array}{l}\text { Intensity } \\
\text { threshold } \\
>1,000^{\mathrm{e}}\end{array}$ & $\begin{array}{c}\text { Intensity } \\
\text { threshold } \\
>2,000^{\circ}\end{array}$ \\
\hline \multirow{23}{*}{$\begin{array}{l}\text { Posttranslational } \\
\text { modification, protein } \\
\text { turnover, chaperones }\end{array}$} & CV438532 & Putative DnaJ homolog subfamily C member 10 (Dnajc10) & Ixodes scapularis & Yes & No \\
\hline & CV446584 & Putative BTB/POZ domain-containing protein 6-A (btbd6a) & Ixodes scapularis & Yes & No \\
\hline & Contig567 & Putative ubiquitinyl hydrolase 16 (USP16), Peptidase C19 family, USP16 subfamily & Ixodes scapularis & Yes & No \\
\hline & Contig7377 & Putative ubiquitinyl hydrolase 8 (USP8), Peptidase C19 family & Saccoglossus kowalevskii & Yes & No \\
\hline & Contig6698 & Putative ubiquitinyl hydrolase L3 (UCHL3), Peptidase C12 family & Trichoplax adhaerens & Yes & No \\
\hline & Contig896 & Putative ubiquitin fusion degradation protein 1 homolog (UFD1L) & Ixodes scapularis & Yes & No \\
\hline & CK188518 & Putative UBX domain-containing protein 4 (UBXN4) & Danio rerio & Yes & No \\
\hline & Contig7693 & Putative ubiquitinyl hydrolase 5 (USP5), Peptidase C19 family & Tribolium castaneum & Yes & No \\
\hline & Contig6367 & Putative gamma-glutamylcyclotransferase B (GGACT B), Gamma-glutamylcyclotransferase family & Ixodes scapularis & Yes & No \\
\hline & Contig8777 & Putative $26 \mathrm{~S}$ proteasome non-ATPase regulatory subunit 12 (PSMD12), Proteasome subunit p55 family & Tribolium castaneum & Yes & No \\
\hline & Contig6300 & Putative arginyltransferase (ATE1), R-transferase family & Monodelphis domestica & Yes & No \\
\hline & Contig8200 & Putative (phosphatase 2A protein)-leucine-carboxy methyltransferase (LCMT1), Methyltransferase superfamily, LCMT family & Ixodes scapularis & Yes & No \\
\hline & Contig202 & Putative T-complex protein 1 subunit delta (TCP-1-delta), TCP-1 chaperonin family & Ixodes scapularis & Yes & No \\
\hline & Contig940 & Putative dehydrodolichyl diphosphate synthase (Dhdds),UPP synthase family & $\begin{array}{l}\text { Strongylocentrotus } \\
\text { purpuratus }\end{array}$ & Yes & No \\
\hline & CV453090 & Putative E3 ubiquitin-protein ligase (HERC3) & Branchiostoma floridae & Yes & No \\
\hline & CK172681 & Putative peptidyl-prolyl cis-trans isomerase FKBP8 (FKBP8) & Ixodes scapularis & Yes & No \\
\hline & Contig7865 & Putative glutaredoxin-related protein 5 (Glrx5), mitochondrial, Glutaredoxin family, Monothiol subfamily & Ixodes scapularis & Yes & No \\
\hline & Contig9047 & Putative glutaredoxin-related protein 5 (Girx5), mitochondrial, Glutaredoxin family, Monothiol subfamily & Ixodes scapularis & Yes & No \\
\hline & Contig1074 & Putative maleylacetoacetate isomerase, GST superfamily, Zeta family & Ixodes scapularis & Yes & No \\
\hline & Contig1596 & Putative glycoprotein 6-alpha-L-fucosyltransferase (alpha1-6FucT), Glycosyltransferase 23 family & Gallus gallus & Yes & No \\
\hline & Contig301 & Putative glycosylphosphatidylinositol anchor attachment 1 protein (GPAA1) & Ixodes scapularis & Yes & No \\
\hline & Contig625 & Putative dolichyl-phosphate beta-glucosyltransferase (ALG5) & Drosophila simulans & Yes & No \\
\hline & Contig3189 & Putative GPI transamidase component PIG-T (PIGT), PIGT family & Ixodes scapularis & Yes & No \\
\hline
\end{tabular}




\begin{tabular}{|c|c|c|c|c|c|}
\hline $\begin{array}{l}\text { Transcript category } \\
{\text { (KOG classification })^{\text {a }}}\end{array}$ & Contig $^{b}$ & Description $^{\mathrm{C}}$ & Species $^{d}$ & $\begin{array}{c}\text { Intensity } \\
\text { threshold } \\
>1,000^{\mathrm{e}}\end{array}$ & $\begin{array}{r}\text { Intensity } \\
\text { threshold } \\
>2,000^{\dagger}\end{array}$ \\
\hline \multirow{7}{*}{$\begin{array}{l}\text { Posttranslational } \\
\text { modification, protein } \\
\text { turnover, chaperones }\end{array}$} & & & & & \\
\hline & CV443627 & Putative GPI transamidase component PIG-S (PIGS), PIGS family & Ixodes scapularis & Yes & No \\
\hline & Contig7928 & Putative mitochondrial intermediate peptidase (MIPEP), Peptidase M3 family & Aedes aegypti & Yes & No \\
\hline & Contig1730 & Putative DnaJ homolog subfamily B member 11 (DNAJB11) & Ixodes scapularis & Yes & No \\
\hline & Contig4002 & Putative DnaJ homolog subfamily A member 3, mitochondrial (DNAJA3) & Aedes aegypti & Yes & No \\
\hline & Contig83A & Putative complex I intermediate-associated protein 30, mitochondria (NDUFAF1), CIA30 family & Ixodes scapularis & Yes & No \\
\hline & Contig3450 & Putative tubulin-specific chaperone A (TBCA), TBCA family & $\begin{array}{l}\text { Pediculus humanus } \\
\text { corporis }\end{array}$ & Yes & No \\
\hline \multirow{14}{*}{$\begin{array}{l}\text { Replication, } \\
\text { recombination and repair }\end{array}$} & Contig5258 & Putative DNA-(apurinic or apyrimidinic site) Iyase (APEX1), DNA repair enzymes AP/ExoA family & Saccoglossus kowalevskii & Yes & No \\
\hline & TC18910 & Putative DNA ligase (ATP) (LIG1), ATP-dependent DNA ligase family & Xenopus laevis & Yes & No \\
\hline & CK177580 & Putative DNA-directed DNA polymerase, alpha catalytic subunit (POLA1), DNA polymerase type-B family & Ixodes scapularis & Yes & No \\
\hline & Contig115 & Putative proliferating cell nuclear antigen (PCNA), PCNA family & Ixodes scapularis & Yes & No \\
\hline & CV457249 & Putative DNA helicase, Maternal DNA replication licensing factor $(\mathrm{mmcm} 3)$, MCM family & Ixodes scapularis & Yes & No \\
\hline & Contig3064 & Putative DNA helicase, DNA replication licensing factor $\mathrm{mcm} 5(\mathrm{mcm} 5)$, MCM family & $\begin{array}{l}\text { Strongylocentrotus } \\
\text { purpuratus }\end{array}$ & Yes & No \\
\hline & Contig6800 & Putative vacuolar protein sorting-associated protein 72 homolog (YL-1), VPS72/YL1 family & Ixodes scapularis & Yes & No \\
\hline & Contig2286 & Putative DNA primase large subunit (PRIM2), Eukaryotic-type primase large subunit family & Ixodes scapularis & Yes & No \\
\hline & CK182406 & Putative DNA mismatch repair protein Msh6 (MSH6), DNA mismatch repair MutS family & Monodelphis domestica & Yes & No \\
\hline & Contig8820 & Putative DNA mismatch repair protein Msh6 (MSH6), DNA mismatch repair MutS family & Ixodes scapularis & Yes & No \\
\hline & Contig5918 & Putative 8-oxo-dGTP diphosphatase (NUDT15), Nudix hydrolase family & Ixodes scapularis & Yes & No \\
\hline & Contig2417 & Putative E3 SUMO-protein ligase NSE2 (NSE2), NSE2 family & Rana catesbeiana & Yes & No \\
\hline & Contig2350 & Putative TIP41-like protein (TIPRL), TIP41 family & Ixodes scapularis & Yes & No \\
\hline & Contig4394 & Putative ribonuclease $\mathrm{H} 2$ subunit $\mathrm{B}$ (RNASEH2B), RNase $\mathrm{H} 2$ subunit $\mathrm{B}$ family & $\begin{array}{l}\text { Strongylocentrotus } \\
\text { purpuratus }\end{array}$ & Yes & No \\
\hline
\end{tabular}




\begin{tabular}{|c|c|c|c|c|c|}
\hline $\begin{array}{l}\text { Transcript category } \\
\text { (KOG classification) }^{a}\end{array}$ & Contig $^{\mathrm{b}}$ & Description ${ }^{\circ}$ & Species $^{d}$ & $\begin{array}{c}\text { Intensity } \\
\text { threshold } \\
>1,000^{\mathrm{e}}\end{array}$ & $\begin{array}{c}\text { Intensity } \\
\text { threshold } \\
>2,000^{\circ}\end{array}$ \\
\hline \multirow[t]{4}{*}{$\begin{array}{l}\text { RNA processing and } \\
\text { modification }\end{array}$} & Contig825 & Putative Serine/arginine-rich splicing factor 7 (SRSF7), Splicing factor SR family & Ixodes scapularis & Yes & Yes \\
\hline & Contig8997 & Putative Serine/arginine-rich splicing factor 7 (SRSF7), Splicing factor SR family & Ixodes scapularis & Yes & Yes \\
\hline & Contig1956 & Putative serine/arginine-rich splicing factor 12 (SRSF12), Splicing factor SR family & Ixodes scapularis & Yes & Yes \\
\hline & Contig4932 & Putative serine/arginine-rich splicing factor RS2Z33 (RS2Z33), Splicing factor SR family & Ixodes scapularis & Yes & Yes \\
\hline \multirow{19}{*}{$\begin{array}{l}\text { RNA processing and } \\
\text { modification }\end{array}$} & Contig5832 & Putative thioredoxin-like protein 4A (Txn|4a),DIM1 family & Ixodes scapularis & Yes & Yes \\
\hline & Contig8773 & Putative serine/arginine-rich splicing factor 12 (SRSF12), Splicing factor SR family & Ixodes scapularis & Yes & Yes \\
\hline & Contig1192 & Putative U2 small nuclear ribonucleoprotein B" (SNRPB2), RRM U1 A/B" family & Nasonia vitripennis & Yes & Yes \\
\hline & Contig5369 & Putative Transformer-2 protein homolog alpha (TRA2A), Splicing factor SR family & Ixodes scapularis & Yes & Yes \\
\hline & Contig6083 & Putative RNA-binding protein with serine-rich domain 1 (RNPS1), Splicing factor SR family & Ixodes scapularis & Yes & No \\
\hline & Contig6666 & Putative serine/arginine-rich splicing factor 4 (SRSF4), Splicing factor SR family & Ixodes scapularis & Yes & No \\
\hline & Contig8231 & Putative RNA helicase (DDX54), DEAD box helicase family. DDX54/DBP10 subfamily & Ixodes scapularis & Yes & No \\
\hline & Contig5357 & Putative RNA helicase (DDX55), DEAD box helicase family, DDX55/SPB4 subfamily & Ixodes scapularis & Yes & No \\
\hline & Contig511 & Putative RNA helicase (DDX43), DEAD box helicase family & Ixodes scapularis & Yes & No \\
\hline & Contig8707 & Putative RNA helicase (DDX52), DEAD box helicase family, DDX52/ROK1 subfamily & Ixodes scapularis & Yes & No \\
\hline & Contig6359 & Putative mRNA (nucleoside-2'-O)-methyltransferase (ttsjd2), Methyltransferase superfamily, RrmJ family & Saccoglossus kowalevskii & Yes & No \\
\hline & Contig3779 & Putative mRNA (nucleoside-2'-O)-methyltransferase (ftsjd2), Methyltransferase superfamily, RrmJ family & Danio rerio & Yes & No \\
\hline & Contig1373 & Putative tRNA (guanine46-N7)-methyltransferase (METTL1), Methyltransferase superfamily, TrmB family & Ixodes scapularis & Yes & No \\
\hline & Contig2428 & $\begin{array}{l}\text { Putative mRNA (guanine-N(7)---methyltransferase (RNMT), Class I-like SAM-binding methyltransferase superfamily, mRNA cap } 0 \\
\text { methyltransferase family }\end{array}$ & Ixodes scapularis & Yes & No \\
\hline & Contig5896 & Putative cleavage stimulation factor subunit 3 (CSTF3) & Ixodes scapularis & Yes & No \\
\hline & Contig4704 & Putative RNA helicase (DDX1), DEAD box helicase family, DDX1 subfamily & Ixodes scapularis & Yes & No \\
\hline & Contig8035 & Putative pre-mRNA processing factor 40 homolog A (PRPF40A), PRPF40 family & Ixodes scapularis & Yes & No \\
\hline & Contig7643 & Putative integrator complex subunit 4 (INTS4), Integrator subunit 4 family & Ixodes scapularis & Yes & No \\
\hline & Contig7662 & Putative pre-mRNA-splicing factor CWC22 homolog (CWC22), CWC22 family & Ixodes scapularis & Yes & No \\
\hline
\end{tabular}




\begin{tabular}{|c|c|c|c|c|c|}
\hline $\begin{array}{l}\text { Transcript category } \\
\text { (KOG classification) }^{\mathrm{a}}\end{array}$ & Contig $^{b}$ & Description ${ }^{\circ}$ & Species $^{d}$ & $\begin{array}{c}\text { Intensity } \\
\text { threshold } \\
>1,000^{\mathrm{e}}\end{array}$ & $\begin{array}{c}\text { Intensity } \\
\text { threshold } \\
>2,000^{\circ}\end{array}$ \\
\hline \multirow[t]{14}{*}{$\begin{array}{l}\text { RNA processing and } \\
\text { modification }\end{array}$} & CV443093 & Putative cleavage stimulation factor subunit 3 (CSTF3) & Ixodes scapularis & Yes & No \\
\hline & CV438199 & Putative U4/U6 small nuclear ribonucleoprotein Prp31 (PRPF31), PRP31 family & Ixodes scapularis & Yes & No \\
\hline & CV449623 & Putative nuclear cap-binding protein subunit 1 (ncbp1), NCBP1 family & Ixodes scapularis & Yes & No \\
\hline & CV449947 & Putative RNA helicase, superkiller viralicidic activity 2-like 2 (SKIV2L2), Helicase family, SKI2 subfamily & Saccoglossus kowalevskii & Yes & No \\
\hline & Contig981 & Putative methylosome protein 50 (WDR77) & Ixodes scapularis & Yes & No \\
\hline & Contig3014 & Putative ribosomal RNA-processing protein 8 (Rrp8), Methyltransferase superfamily, RRP8 family & Tribolium castaneum & Yes & No \\
\hline & Contig6223 & Putative Pescadillo homolog (PES1), Pescadillo family & Tetraodon nigroviridis & Yes & No \\
\hline & Contig5044 & Putative U6 snRNA-associated Sm-like protein LSm4 (LSM4), SnRNP Sm proteins family & Nematostella vectensis & Yes & No \\
\hline & TC19865 & Putative small nuclear ribonucleoprotein Sm D2 (SNRPD2), SnRNP core protein family & Ixodes scapularis & Yes & No \\
\hline & Contig3309 & Putative Small nuclear ribonucleoprotein Sm D3 (SNRPD3), SnRNP core protein family & Ixodes scapularis & Yes & No \\
\hline & Contig7040 & Putative tRNA (guanine(37)-N(1))-methyltransferase (TRM5), TRM5 / TYW2 family & Tetraodon nigroviridis & Yes & No \\
\hline & Contig734 & Putative U3 small nucleolar ribonucleoprotein protein IMP3 (IMP3), Ribosomal protein S4P family & Saccoglossus kowalevskii & Yes & No \\
\hline & Contig4769 & Putative Protein FAM98B (FAM98B), FAM98 family & Danio rerio & Yes & No \\
\hline & Contig3752 & Putative RNA ligase (ATP), tRNA-splicing ligase RtcB homolog (rtcB), RtcB family & Ixodes scapularis & Yes & No \\
\hline \multicolumn{6}{|l|}{ Secondary metabolites } \\
\hline \multirow{2}{*}{$\begin{array}{l}\text { biosynthesis, transport } \\
\text { and catabolism }\end{array}$} & Contig701 & Putative MOSC domain-containing protein 1 , mitochondrial (MARC1) & Ixodes scapularis & Yes & No \\
\hline & Contig4351 & $\begin{array}{l}\text { Putative phosphopantothenoylcysteine decarboxylase (PPCDC), HFCD (homo-oligomeric flavin containing Cys decarboxylase) } \\
\text { superfamily }\end{array}$ & Ixodes scapularis & Yes & No \\
\hline \multirow{4}{*}{$\begin{array}{l}\text { Signal transduction } \\
\text { mechanisms }\end{array}$} & Contig426 & Putative stromal membrane-associated protein 1 (SMAP1) & Ixodes scapularis & Yes & Yes \\
\hline & Contig615 & Putative myosin-light-chain kinase (MYLK), Protein kinase superfamily, CAMK Ser/Thr protein kinase family & Apis mellifera & Yes & Yes \\
\hline & Contig2242 & Putative growth hormone-inducible transmembrane protein (GHITM), Bl1 family & Branchiostoma floridae & Yes & Yes \\
\hline & Contig5174 & Putative Hsp90 co-chaperone Cdc37 (Cdc37), CDC37 family & Ixodes scapularis & Yes & No \\
\hline
\end{tabular}




\begin{tabular}{|c|c|c|c|c|c|}
\hline $\begin{array}{l}\text { Transcript category } \\
\text { (KOG classification) }^{\mathrm{a}}\end{array}$ & Contig $^{\mathrm{b}}$ & Description $^{\circ}$ & Species $^{\mathrm{d}}$ & $\begin{array}{c}\text { Intensity } \\
\text { threshold } \\
>1,000^{\mathrm{e}}\end{array}$ & $\begin{array}{c}\text { Intensity } \\
\text { threshold } \\
>2,000^{\circ}\end{array}$ \\
\hline \multirow[t]{14}{*}{$\begin{array}{l}\text { Signal transduction } \\
\text { mechanisms }\end{array}$} & Contig7343 & Putative COP9 signalosome complex subunit 5 (COPS5), Peptidase M67A family, CSN5 subfamily & $\begin{array}{l}\text { Xenopus (Silurana) } \\
\text { tropicalis }\end{array}$ & Yes & No \\
\hline & Contig6843 & Putative phosphatidylinositol 4-kinase alpha (PI4KA), PI3/PI4-kinase family, Type III PI4K subfamily & Ixodes scapularis & Yes & No \\
\hline & Contig7509 & Putative peptidylprolyl isomerase activator (PPP2R4), PTPA-type PPlase family & Harpegnathos saltator & Yes & No \\
\hline & Contig3367 & Putative glucosidase 2 subunit beta (PRKCSH) & $\begin{array}{l}\text { Pediculus humanus } \\
\text { corporis }\end{array}$ & Yes & No \\
\hline & Contig5579 & Putative non-specific serine/threonine protein kinase (SRPK2), Protein kinase superfamily, CMGC Ser/Thr protein kinase family & Nasonia vitripennis & Yes & No \\
\hline & Contig6537 & Putative hepatitis B virus X-interacting protein (HBXIP), HBXIP family & Ixodes scapularis & Yes & No \\
\hline & Contig3503 & Putative mitogen-activated protein kinase-binding protein 1 (MAPKBP1) & Ixodes scapularis & Yes & No \\
\hline & Contig264 & Putative mitogen-activated protein kinase-binding protein 1 (MAPKBP1) & Ixodes scapularis & Yes & No \\
\hline & Contig7015 & Putative DCC-interacting protein 13-alpha (APPL1) & Ixodes scapularis & Yes & No \\
\hline & Contig5766 & $\begin{array}{l}\text { Putative 1-alkyl-2-acetylglycerophosphocholine esterase, Platelet-activating factor acetylhydrolase IB subunit gamma (PAFAH1B3), } \\
\text { 'GDSL' lipolytic enzyme family, Platelet-activating factor acetylhydrolase IB beta/gamma subunits subfamily }\end{array}$ & Ixodes scapularis & Yes & No \\
\hline & Contig3634 & Putative calcyclin-binding protein (CACYBP) & Xenopus laevis & Yes & No \\
\hline & Contig2429 & Putative developmentally-regulated GTP-binding protein 2 (DRG2), GTP1/OBG family & Ixodes scapularis & Yes & No \\
\hline & Contig6702 & Putative A-kinase anchor protein 1, mitochondrial (AKAP1) & $\begin{array}{l}\text { Pediculus humanus } \\
\text { corporis }\end{array}$ & Yes & No \\
\hline & Contig3619 & Putative SLIT-ROBO Rho GTPase-activating protein 1 (SRGAP1) & Ixodes scapularis & Yes & No \\
\hline \multirow[t]{8}{*}{ Transcription } & Contig5083 & Putative DNA helicase (RUVBL2), RuvB family & Ixodes scapularis & Yes & Yes \\
\hline & Contig346 & Putative protein dpy-30 homolog (DPY30), Dpy-30 family & Ixodes scapularis & Yes & Yes \\
\hline & Contig1649 & Putative transcription factor BTF3 homolog 4 (BTF3L4), NAC-beta family & Ixodes scapularis & Yes & Yes \\
\hline & Contig8810 & Putative nascent polypeptide-associated complex subunit alpha (NACA), NAC-alpha family & Ixodes scapularis & Yes & Yes \\
\hline & Contig6772 & Putative X-box-binding protein 1 (XBP1), BZIP family & Ixodes scapularis & Yes & Yes \\
\hline & Contig137 & Putative protein arginine $\mathrm{N}$-methyltransferase (PRMT1), Protein arginine $\mathrm{N}$-methyltransferase family & Ixodes scapularis & Yes & Yes \\
\hline & Contig6562 & Putative zinc finger protein 132 (ZNF132), Krueppel C2H2-type zinc-finger protein family & Ixodes scapularis & Yes & No \\
\hline & Contig2160 & Putative zinc finger protein 84 (ZNF84), Krueppel C2H2-type zinc-finger protein family & Danio rerio & Yes & No \\
\hline
\end{tabular}




\begin{tabular}{|c|c|c|c|c|c|}
\hline $\begin{array}{l}\text { Transcript category } \\
\text { (KOG classification) }^{a}\end{array}$ & Contig $^{b}$ & Description ${ }^{\mathrm{C}}$ & Species $^{d}$ & $\begin{array}{c}\text { Intensity } \\
\text { threshold } \\
>1,000^{\mathrm{e}}\end{array}$ & $\begin{array}{c}\text { Intensity } \\
\text { threshold } \\
>2,000^{\circ}\end{array}$ \\
\hline \multirow[t]{22}{*}{ Transcription } & Contig3540 & $\begin{array}{l}\text { Putative transcription factor Dp-1 (TFDP1), E2F/DP family } \\
\end{array}$ & Ixodes scapularis & Yes & No \\
\hline & CV446980 & Putative Protein daughterless (da) & Apis mellifera & Yes & No \\
\hline & Contig7438 & Putative DNA-directed RNA polymerase II subunit RPB3 (POLR2C), Archaeal rpoD/eukaryotic RPB3 RNA polymerase subunit family & Ixodes scapularis & Yes & No \\
\hline & Contig3039 & Putative transcription elongation factor S-II (TfIIS), TFS-II family & Ixodes scapularis & Yes & No \\
\hline & Contig811 & Putative polycomb protein EED (EED), WD repeat ESC family & Ixodes scapularis & Yes & No \\
\hline & Contig1466 & Putative rRNA-processing protein FCF2 (FCF2), FCF2 family & Ixodes scapularis & Yes & No \\
\hline & TC15275 & Putative Huntington disease protein homolog, May play a role in microtubule-mediated transport or vesicle function & Ixodes scapularis & Yes & No \\
\hline & Contig745 & Putative zinc finger HIT domain-containing protein 3 (ZNHIT3), HIT-type zinc finger & Ixodes scapularis & Yes & No \\
\hline & Contig4415 & Putative mediator of RNA polymerase II transcription subunit 21 (MED21), Mediator complex subunit 21 family & Ixodes scapularis & Yes & No \\
\hline & Contig380 & Putative transcription initiation factor IIA subunit 1 (GTF2A1), TFIIA subunit 1 family & Ixodes scapularis & Yes & No \\
\hline & Contig2530 & Putative DNA-directed RNA polymerase III subunit RPC6 (POLR3F), Eukaryotic RPC34/RPC39 RNA polymerase subunit family & Branchiostoma floridae & Yes & No \\
\hline & Contig5236 & $\begin{array}{l}\text { Putative DNA-directed RNA polymerases I, II, and III subunit RPABC2 (POLR2F), Archaeal rpoK/eukaryotic RPB6 RNA polymerase } \\
\text { subunit family }\end{array}$ & Ixodes scapularis & Yes & No \\
\hline & Contig255A & Putative enhancer of yellow 2 transcription factor homolog (eny2), ENY2 family & Ixodes scapularis & Yes & No \\
\hline & CK183629 & Putative mediator of RNA polymerase II transcription subunit 10 (MED10), Mediator complex subunit 10 family & Ixodes scapularis & Yes & No \\
\hline & Contig5558 & Putative transcription initiation factor TFIID subunit 10 (TAF10), TAF10 family & Ixodes scapularis & Yes & No \\
\hline & Contig4186 & Putative activated RNA polymerase II transcriptional coactivator p15 (SUB1), Transcriptional coactivator PC4 family & Ixodes scapularis & Yes & No \\
\hline & CK190403 & Putative zinc finger protein 593 (ZNF593), ZNF593/BUD20 C2H2-type zinc-finger protein family & Ixodes scapularis & Yes & No \\
\hline & TC16293 & Putative (Histone H3)-Iysine-36 demethylase (NO66), MINA53/NO66 family, NO66 subfamily & Ixodes scapularis & Yes & No \\
\hline & CV435794 & Putative mediator of RNA polymerase II transcription subunit 17 (MED17), Mediator complex subunit 17 family & Apis mellifera & Yes & No \\
\hline & TC17107 & Putative mediator of RNA polymerase II transcription subunit 8 (Med8), Mediator complex subunit 8 family & Ixodes scapularis & Yes & No \\
\hline & U92783.1 & Putative PHD finger protein 12 (PHF12) & Ixodes scapularis & Yes & No \\
\hline & Contig1806 & Putative PHD finger protein 23B (phf23b), PHF23 family & Ixodes scapularis & Yes & No \\
\hline \multirow{2}{*}{$\begin{array}{l}\text { Translation, ribosomal } \\
\text { structure and biogenesis }\end{array}$} & Contig1577 & Putative H/ACA ribonucleoprotein complex subunit 2-like protein (NHP2), Ribosomal protein L7Ae family & Ixodes scapularis & Yes & Yes \\
\hline & Contig7181 & Putative 40 S ribosomal protein S25 (RPS25), Ribosomal protein S25e family & Ixodes scapularis & Yes & Yes \\
\hline
\end{tabular}




\begin{tabular}{|c|c|c|c|c|c|}
\hline 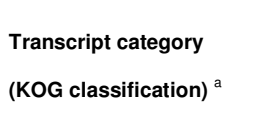 & Contig $^{b}$ & Description $^{\mathrm{C}}$ & Species $^{d}$ & $\begin{array}{l}\text { Intensity } \\
\text { threshold } \\
>1,000^{\mathrm{e}}\end{array}$ & $\begin{array}{l}\text { Intensity } \\
\text { threshold } \\
>2,000^{\dagger}\end{array}$ \\
\hline \multirow{22}{*}{$\begin{array}{l}\text { Translation, ribosomal } \\
\text { structure and biogenesis }\end{array}$} & EW680164.1 & Putative 40S ribosomal protein S29 (RPS29), Ribosomal protein S14P family & Ixodes scapularis & Yes & Yes \\
\hline & Contig1238 & Putative 60S Ribosomal protein L13 (RPL13), Ribosomal protein L13e family & Ornithodoros parkeri & Yes & Yes \\
\hline & Contig3228 & Putative 60s ribosomal protein L27a (RPL27A), Ribosomal protein L15P family & Ornithodoros coriaceus & Yes & Yes \\
\hline & EW680050.1 & Putative 60S ribosomal protein L24 (RPL24), Ribosomal protein L24e family & $\begin{array}{l}\text { Hyalomma anatolicum } \\
\text { anatolicum }\end{array}$ & Yes & Yes \\
\hline & Contig6473 & Putative 60S ribosomal protein L26 (RPL26), Ribosomal protein L24P family & Lycosa singoriensis & Yes & Yes \\
\hline & Contig107B & Putative 60S ribosomal protein L27 (RPL27), Ribosomal protein L27e family & Ixodes scapularis & Yes & Yes \\
\hline & Contig5017 & Putative ribosome biogenesis protein RLP24 (RPL24), Ribosomal protein L24e family & $\begin{array}{l}\text { Strongylocentrotus } \\
\text { purpuratus }\end{array}$ & Yes & Yes \\
\hline & Contig9000 & Putative 60 S ribosomal protein L32 (RPL32), Ribosomal protein L32P family & $\begin{array}{l}\text { Hyalomma marginatum } \\
\text { rufipes }\end{array}$ & Yes & Yes \\
\hline & CK177858 & Putative 60 S ribosomal protein L37a (RPL37A), Ribosomal protein L37Ae family & Ixodes scapularis & Yes & Yes \\
\hline & Contig1990 & Putative arginine-tRNA ligase (RARS), Class-I aminoacyl-tRNA synthetase family & Ixodes scapularis & Yes & Yes \\
\hline & Contig7496 & Putative 60 S ribosomal protein $L 41$ (RPL41), Ribosomal protein L41e family & Vitis vinifera & Yes & Yes \\
\hline & Contig2946 & Putative 39S ribosomal protein L32, mitochondrial (MRPL32), Ribosomal protein L32P family & Drosophila willistoni & Yes & Yes \\
\hline & TC20332 & Putative $28 \mathrm{~S}$ ribosomal protein S15, mitochondrial (bonsai), Ribosomal protein S15P family & Ixodes scapularis & Yes & Yes \\
\hline & Contig2574 & Putative eukaryotic translation initiation factor 3 subunit $G(E I F 3 G)$, elF-3 subunit $G$ family & Ixodes scapularis & Yes & Yes \\
\hline & Contig4252 & Putative nucleolin (NUCL) & Ixodes scapularis & Yes & No \\
\hline & Contig8886 & Putative nucleolar protein 56 (NOP56), NOP5/NOP56 family & Ixodes scapularis & Yes & No \\
\hline & Contig314B & Putative 40S ribosomal protein S24 (Rps24), ribosomal protein S24e family & Dermacentor variabilis & Yes & No \\
\hline & Contig2998 & Putative ribosomal protein L1 (mrpl1), mitochondrial, Ribosomal protein L1P family & Ixodes scapularis & Yes & No \\
\hline & Contig5814 & Putative 60S ribosomal protein L19 (RPL19), Ribosomal protein L19e family & Ornithodoros parkeri & Yes & No \\
\hline & Contig7903 & Putative D-tyrosyl-tRNA(Tyr) deacylase 1 (DTD1), DTD family & Ixodes scapularis & Yes & No \\
\hline & Contig4298 & Putative HBS1-like protein (HBS1L), GTP-binding elongation factor family & Ixodes scapularis & Yes & No \\
\hline & Contig5945 & Putative exosome complex exonuclease RRP46 (EXOSC5), RNase PH family & Ixodes scapularis & Yes & No \\
\hline
\end{tabular}




\begin{tabular}{|c|c|c|c|c|c|}
\hline $\begin{array}{l}\text { Transcript category } \\
\text { (KOG classification) }^{a}\end{array}$ & Contig $^{b}$ & Description $^{\mathrm{c}}$ & Species $^{d}$ & $\begin{array}{c}\text { Intensity } \\
\text { threshold } \\
>1,000^{\mathrm{e}}\end{array}$ & $\begin{array}{c}\text { Intensity } \\
\text { threshold } \\
>2,000^{\circ}\end{array}$ \\
\hline \multirow{23}{*}{$\begin{array}{l}\text { Translation, ribosomal } \\
\text { structure and biogenesis }\end{array}$} & Contig5596 & Putative H/ACA ribonucleoprotein complex subunit 1 (GAR1), GAR1 family & Ixodes scapularis & Yes & No \\
\hline & Contig2724 & Putative histidine-tRNA ligase (HARS), Class-II aminoacyl-tRNA synthetase family & Branchiostoma floridae & Yes & No \\
\hline & CV454305 & Putative isoleucine-tRNA ligase (IARS), Class-I aminoacyl-tRNA synthetase family & Ixodes scapularis & Yes & No \\
\hline & Contig2011 & $\begin{array}{l}\text { Putative Protein pelota homolog (PELO), Eukaryotic release factor } 1 \text { family, Pelota subfamily, Required for normal chromosome } \\
\text { segregation during cell division and genomic stability }\end{array}$ & Drosophila ananassae & Yes & No \\
\hline & Contig8302 & Putative methionyl-tRNA formyltransferase, mitochondrial (MTFMT), Fmt family & Ixodes scapularis & Yes & No \\
\hline & Contig1776 & Putative elongation factor Tu, mitochondrial (EfTuM), GTP-binding elongation factor family, EF-Tu/EF-1A subfamily & Ixodes scapularis & Yes & No \\
\hline & Contig8438 & Putative 39S ribosomal protein L3, mitochondrial (Mrp|3), Ribosomal protein L3P family & Ixodes scapularis & Yes & No \\
\hline & Contig7444 & Putative Pre-rRNA-processing protein TSR1 homolog (TSR1), BMS1/TSR1 family. TSR1 subfamily & Ixodes scapularis & Yes & No \\
\hline & Contig3804 & Putative ribosome biogenesis protein BOP1 (BOP1), WD repeat BOP1/ERB1 family & Branchiostoma floridae & Yes & No \\
\hline & Contig714 & Putative probable RNA-binding protein EIF 1 AD, EIF 1 AD family & Ixodes scapularis & Yes & No \\
\hline & Contig2450 & Putative $28 \mathrm{~S}$ ribosomal protein S28, mitochondrial (MRPS28) & $\begin{array}{l}\text { Anopheles gambiae str. } \\
\text { PEST }\end{array}$ & Yes & No \\
\hline & Contig1578 & Putative $28 \mathrm{~S}$ ribosomal protein $\mathrm{S} 5$, mitochondrial (MRPS5), Ribosomal protein S5P family & Ixodes scapularis & Yes & No \\
\hline & Contig252 & Putative Ribosome biogenesis protein BRX1 homolog (BRIX1), BRX1 family & Tribolium castaneum & Yes & No \\
\hline & CV453853 & Putative RNA helicase, eukaryotic initiation factor 4A (EIF4A1), DEAD box helicase family, elF4A subfamily & Ixodes scapularis & Yes & No \\
\hline & Contig7689 & Putative aminoacyl tRNA synthase complex-interacting multifunctional protein 1 (AIMP1) & Ixodes scapularis & Yes & No \\
\hline & Contig4817 & Putative mitochondrial ribosomal S23 protein (MRPS23) & Drosophila willistoni & Yes & No \\
\hline & Contig6275 & Putative mitochondrial 39S ribosomal protein L38 (MRPL38) & Ixodes scapularis & Yes & No \\
\hline & Contig1485 & Putative ribosome biogenesis protein WDR12 (WDR12), WD repeat WDR12/YTM1 family & Ixodes scapularis & Yes & No \\
\hline & Contig1046 & Putative Box C/D snoRNA protein 1 (ZNHIT6), BCD1 family & Ixodes scapularis & Yes & No \\
\hline & Contig8406 & Putative aminoacyl-tRNA hydrolase (PTRH2), PTH2 family & Ixodes scapularis & Yes & No \\
\hline & Contig5024 & Putative nuclear nucleic acid-binding protein C1D (C1D), C1D family & Ixodes scapularis & Yes & No \\
\hline & Contig308 & Putative 39 S ribosomal protein $L 37$, mitochondrial (MRPL37), Ribosomal protein S30/L37 family & Ixodes scapularis & Yes & No \\
\hline & CK189708 & Putative $28 \mathrm{~S}$ ribosomal protein $\mathrm{S} 6$, mitochondrial (MRPS6), Ribosomal protein S6P family & Ixodes scapularis & Yes & No \\
\hline
\end{tabular}




\begin{tabular}{|c|c|c|c|c|c|}
\hline $\begin{array}{l}\text { Transcript category } \\
\text { (KOG classification) }^{\mathrm{a}}\end{array}$ & Contig $^{\mathrm{b}}$ & Description ${ }^{\circ}$ & Species $^{d}$ & $\begin{array}{c}\text { Intensity } \\
\text { threshold } \\
>1,000^{\mathrm{e}}\end{array}$ & $\begin{array}{c}\text { Intensity } \\
\text { threshold } \\
>2,000^{\circ}\end{array}$ \\
\hline \multirow{13}{*}{$\begin{array}{l}\text { Translation, ribosomal } \\
\text { structure and biogenesis }\end{array}$} & Contig643 & Putative $28 \mathrm{~S}$ ribosomal protein $\mathrm{S} 10$, mitochondrial (MRPS10), Ribosomal protein S10P family & Ixodes scapularis & Yes & No \\
\hline & TC19757 & Putative $28 \mathrm{~S}$ ribosomal protein S18b, mitochondrial (MRPS18B), Ribosomal protein S18P family & Ixodes scapularis & Yes & No \\
\hline & Contig1020 & Putative 39S ribosomal protein L19, mitochondrial (MRPL19), Ribosomal protein L19P family & Ixodes scapularis & Yes & No \\
\hline & Contig405 & Putative 39S ribosomal protein L24, mitochondrial (MRPL24), Ribosomal protein L24P family & Ixodes scapularis & Yes & No \\
\hline & Contig5697 & Putative $28 \mathrm{~S}$ ribosomal protein S14, mitochondrial, mitochondrial (MRPS14), Ribosomal protein S14P family & Ixodes scapularis & Yes & No \\
\hline & Contig7858 & Putative 28S ribosomal protein S16, mitochondrial (MRPS16), Ribosomal protein S16P family & Ixodes scapularis & Yes & No \\
\hline & Contig4891 & Putative $28 \mathrm{~S}$ ribosomal protein S18c, mitochondrial (MRPS18C), Ribosomal protein S18P family & Ixodes scapularis & Yes & No \\
\hline & CV440148 & Putative nucleolar protein 6 (NOL6), NRAP family & Ixodes scapularis & Yes & No \\
\hline & Contig3182 & Putative rRNA-processing protein FCF1 homolog (FCF1), UTP23/FCF1 family, FCF1 subfamily & Ixodes scapularis & Yes & No \\
\hline & TC20881 & Putative nucleolar complex protein 4 homolog (NOC4L), CBF/MAK21 family & Ixodes scapularis & Yes & No \\
\hline & Contig4879 & Putative $39 S$ ribosomal protein $L 48$, mitochondrial (MRPL48) & Ixodes scapularis & Yes & No \\
\hline & Contig3662 & Putative 39S ribosomal protein L35, mitochondrial (MRPL35), Ribosomal protein L35P family & Drosophila persimilis & Yes & No \\
\hline & Contig4524 & Putative 39S ribosomal protein L28, mitochondrial (MRPL28), Ribosomal protein L28P family & Ixodes scapularis & Yes & No \\
\hline
\end{tabular}

${ }^{a}$ Classification of transcripts according to eukaryotic ortologous group terms for gene ontology (Tatusov et al., 2003).

${ }^{\mathrm{b}}$ Assigned contiguous sequence identification for transcripts following assembly of all available expressed sequence tags and the $R$. microplus Gene Index version 2.1.

${ }^{\mathrm{c}}$ The functional annotation of genes based on comparison among BLAST outputs from seven databases outlined in Section 2.4. All transcript descriptions are based on consensus with database entries from Uniprot (http://www.uniprot.org/uniprot/) and BRENDA (http://www.brenda-enzymes.org/), in the case of enzymes.

${ }^{d}$ Species indicated that showed the highest sequence similarity to R. microplus sequences following non-redundant database (NR) BLAST analysis, independent of final assignment.

${ }^{e}$ Transcripts with $\mathrm{M}$ values $>0$ and Cy5 intensities $>1,000$ in all tissues tested that are considered to be shared

${ }^{\mathrm{f}}$ Transcripts with $\mathrm{M}$ values $>0$ and Cy5 intensities $>2,000$ in all tissues tested that are considered to be shared 
Supplementary Table S6. Verification of differential gene expression of selected transcripts by quantitative reverse transcriptase (qRT-PCR).

\begin{tabular}{|c|c|c|c|c|c|}
\hline Contig $^{a}$ & Description $^{b}$ & Comparison $^{\mathrm{c}}$ & $\begin{array}{l}\text { Microarray fold } \\
\text { change }^{d}\end{array}$ & $\begin{array}{c}\text { qRT-PCR } \\
\text { fold } \\
\text { change }^{\text {e }}\end{array}$ & $\begin{array}{l}\text { Direction of } \\
\text { change }\end{array}$ \\
\hline Contig8418 & Elongation factor 1 alpha & MG/SG & ND & 0.94 & Unaffected \\
\hline Contig8723 & $\begin{array}{l}\text { Putative } 60 S \text { ribosomal protein L9, } \\
\text { Ribosomal protein L6P family }\end{array}$ & MG/SG & $0.93^{f}$ & $1.06^{f}$ & Unaffected \\
\hline Contig1 & $\begin{array}{l}\text { Putative angiotensin-converting } \\
\text { enzyme, Peptidase M2 family }\end{array}$ & MG/SG & $0.12^{f}$ & $6.43 E-03^{f}$ & Down \\
\hline Contig5396 & Putative mucin & MG/SG & $19.61^{f}$ & $17.66^{f}$ & Up \\
\hline Contig5672 & Unknown protein & MG/SG & $2.81^{f}$ & $7.05^{f}$ & Up \\
\hline
\end{tabular}

${ }^{\mathrm{a}}$ Assigned contiguous sequence identification for transcripts following assembly of all available expressed sequence tags and the Rhipicephalus microplus Gene Index version 2.1.

$\mathrm{b}$ The functional annotation of genes based on comparison among BLAST outputs from seven databases outlined in Materials and methods. All transcript descriptions are based on consensus with database entries from Uniprot (http://www.uniprot.org/uniprot/) and BRENDA (http://www.brenda-enzymes.org/), in the case of enzymes.

${ }^{\mathrm{c}}$ Pairwise tissue comparison indicated for midgut (MG) and salivary glands (SG) .

${ }^{d}$ Fold change (absolute) for microarray calculated from the $\log _{2}$ expression level for the gene $(P$ value $\leq 0.001)$.

${ }^{e}$ Fold change data identified from qRT-PCR. The data was normalized against Contig 8418 and Contig 8723 and fold changes are expressed according to the current tissue comparison (i.e. midgut to salivary gland, MG/SG).

${ }^{\mathrm{f}}$ These values demonstrated a high correlation at 0.96 with the microarray and qRT-PCR data, calculated by using Pearson linear regression ( $R$ squared value of 0.93 ).

ND, not determined 